THIAGO VILLAS BÔAS ZANON

\title{
AVALIAÇÃO DA CONTAMINAÇÃO DE UM SOLO LATERÍTICO POR LIXIVIADO DE ATERRO SANITÁRIO ATRAVÉS DE ENSAIOS DE LABORATÓRIO E ANÁLISE DE DADOS DE CAMPO
}


THIAGO VILLAS BÔAS ZANON

\section{AVALIAÇÃO DA CONTAMINAÇÃO DE UM SOLO LATERÍTICO POR LIXIVIADO DE ATERRO SANITÁRIO ATRAVÉS DE ENSAIOS DE LABORATÓRIO E ANÁLISE DE DADOS DE CAMPO}

Dissertação apresentada à Escola Politécnica da Universidade de São Paulo para obtenção do título de Mestre em Engenharia

Área de concentração: Engenharia Geotécnica

Orientadora: Professora Titular Maria Eugenia Gimenez Boscov

São Paulo

2014 
Este exemplar foi revisado e corrigido em relação à versão original, sob responsabilidade única do autor e com a anuência de seu orientador.

São Paulo, 04 de fevereiro de 2014.

Assinatura do autor

Assinatura do orientador

\section{FICHA CATALOGRÁFICA}

Zanon, Thiago Villas Bôas

Avaliação da contaminação de um solo laterítico por lixiviado de aterro sanitário através de ensaios de laboratório e análise de dados de campo / T.V.B. Zanon. -- versão corr. -- São Paulo, 2014.

$101 \mathrm{p}$.

Dissertação (Mestrado) - Escola Politécnica da Universidade de São Paulo. Departamento de Engenharia de Estruturas e Geotécnica.

1.Solo laterítico 2.Resíduos sólidos 3.Resíduos urbanos 4.Lixiviação do solo I.Universidade de São Paulo. Escola Politécnica. Departamento de Engenharia de Estruturas e Geotécnica II.t. 


\section{DEDICATÓRIA}

Aos

Meus Pais: Maria Teresa e Nilton

Minha Avó: Ilia

Minha Noiva: Patricie 


\section{AGRADECIMENTOS}

Meus sinceros agradecimentos a todos que de alguma forma me apoiaram, inspiraram e orientaram nesta jornada de minha vida, da qual tirei valorosas lições.

Aos meus pais Maria Teresa Villas Bôas Zanon e Nilton Saad Zanon, pelo fundamental apoio e incentivo aos estudos.

À minha avó llia Leonis Villas Bôas, que me ajudou a construir os pilares para sustentação do conhecimento e iniciar a construção da busca pela sabedoria.

À querida orientadora, Prof. Titular Maria Eugênia Gimenez Boscov, pela dedicação e orientação.

Aos professores Elisabeth Ritter, lara Camargo e Paulo Hemsi, por suas valorosas observações durante o Exame de Qualificação e de Defesa.

Aos meus ex-chefes e amigos Pedro Paulo Furtado Gouveia Filho e Clóvis Benvenuto, por apoiarem a realização do curso de mestrado e permitirem partilhar da divisão dos estudos com as atividades profissionais. Ao meu atual chefe Alexandre de Almeida Prado Ferrari, por tal apoio e permitir também tal partilha, além da oportuna sugestão da investigação desta pesquisa.

Ao Antônio Heiztmann e Daissy Rodriguez Bedoya, pela valorosa colaboração nas amostragens de campos e auxílio nos ensaios geotécnicos.

À Luci Monteiro, pelas orientações para as preparações de amostras e ensaios químicos.

Aos amigos do CEPEMA, Osmar Gomes e Rafaela Araújo, e da Central Analítica, Michele Rocha e Rebeca Yatsuzuka, pelo grande auxílio e instruções na execução dos ensaios químicos.

À Revita Engenharia por permitir o estudo de caso no aterro sanitário de Botucatu. Em especial ao Gabriel Lopes, Jarbas Scaff, João Paulo Eleutério, Leonardo Parize e Norberto Vega, pelo apoio nas atividades de campo. 
Aos meus familiares e amigos, pelo grande incentivo nesta importante etapa de minha vida. Ao meu irmão Gabriel, por ceder o espaço do quarto muitas vezes para propiciar um ambiente tranquilo para escrever a dissertação.

Ao Pedro Dib, da Sanifox do Brasil, pela coleta das amostras contaminadas de campo desta pesquisa.

Ao amigo e mestre André Marguti pelas palavras de incentivo!

À Fundação de Amparo a Pesquisa do Estado de São Paulo - FAPESP, pelo suporte financeiro.

E deixei por fim, mas não menos importante - sem dúvida alguma o contrário -, à minha noiva Patricie Barricelli, grande amor da minha vida, por me apoiar nas atividades do mestrado e por abdicar muitos momentos de convívio para finalização do mestrado. 


\section{RESUMO}

Esta dissertação de mestrado tem como objetivo principal avaliar o transporte de poluentes de um lixiviado real de aterro sanitário em um solo laterítico do estado de São Paulo. A pesquisa objetiva também comparar dois métodos de avaliação de transporte de poluentes: ensaios laboratoriais e análise de dados de contaminação de campo.

No aterro sanitário de Botucatu houve, comprovadamente, percolação do lixiviado pelo subsolo durante aproximadamente 15 anos, sob uma lagoa de acumulação de lixiviado sem revestimento de fundo. Foram coletadas amostras de solo subjacente à lagoa, uma areia argilosa, em três perfis verticais na superfície e nas profundidades de 0,25 m, 0,50 m, 1,00 m, 2,00 m e 4,00 m. Os poluentes investigados foram: arsênio, cádmio, carbono orgânico total (COT), chumbo, cloreto, cobre, cromo, ferro, manganês, níquel, nitrogênio Kjeldahl total (NKT) e zinco.

Amostras indeformadas do solo local não contaminado foram também coletadas para ensaios de permeabilidade à água e ao lixiviado, assim como para ensaios de coluna. A condutividade hidráulica do solo é da ordem de $10^{-6} \mathrm{~m} / \mathrm{s}$, porém significativamente influenciada pelo gradiente hidráulico aplicado e pela duração da percolação. A condutividade hidráulica diminuiu com a percolação de lixiviado para ordens de grandeza entre $10^{-8}$ e $10^{-6} \mathrm{~m} / \mathrm{s}$, dependendo do gradiente hidráulico. Os ensaios de coluna mostraram concentrações efluentes dos elementos pesquisados superiores às afluentes, impossibilitando a obtenção de parâmetros de transporte de poluentes.

A análise das amostras contaminadas coletadas in situ mostrou que, embora o solo local seja poroso e apresente alta permeabilidade, as concentrações dos elementos estudados eram inferiores aos limites legais de contaminação do órgão de controle ambiental estadual. $O$ cloreto e o nitrogênio, para os quais não há limites legais, apresentaram-se no subsolo em concentrações elevadas, superiores às concentrações no solo natural e, em algumas amostras, às do lodo depositado no fundo da lagoa.

Palavras-chave: transporte de poluentes, solos tropicais lateríticos, lixiviado, resíduos sólidos urbanos, aterro sanitário. 


\section{ABSTRACT}

The aim of this research is to evaluate transport of pollutants from a sanitary landfill leachate through a Brazilian lateritic soil by two methods: laboratory tests and analysis of field contamination.

In Botucatu Sanitary Landfill, leachate stored in an unlined pond infiltrated into the subsoil for 15 years. Samples of the subjacent soil, a porous clayey sand, were collected in three profiles located inside the area of the leachate pond at the following depths: surface, $0.25 \mathrm{~m}, 0.50 \mathrm{~m}, 1.00 \mathrm{~m}, 2.00 \mathrm{~m}$ and $4.00 \mathrm{~m}$. The investigated pollutants were arsenic, cadmium, chloride, cooper, iron, lead, manganese, nickel, Kjeldahl nitrogen, total organic carbon (TOC) and zinc.

The hydraulic conductivity measured in undisturbed and uncontaminated samples of the local soil, around $10^{-6} \mathrm{~m} / \mathrm{s}$, is significantly influenced by the applied hydraulic gradient and the percolation duration. When leachate substituted water as percolation fluid, the hydraulic conductivity decreased to values between $10^{-8}$ and $10^{-6} \mathrm{~m} / \mathrm{s}$ depending on the hydraulic gradient.

Chemical analysis of contaminated samples showed that concentrations of the researched elements in the subsoil were lower than legal maximum contamination limits established by the environmental agency of São Paulo state, in spite of the fact that the local soil is porous and has high hydraulic conductivity. On the other hand, chloride and Kjeldahl nitrogen, pollutants for which there are no legal limits, were found in concentrations much higher than background values, and in some samples even higher than those measured in the leachate sludge deposited in the bottom of the storage pond.

Keywords: pollutant transport, lateritic tropical soil, leachate, municipal solid waste, sanitary landfill. 


\section{LISTA DE FIGURAS}

Figura 3-1 - Exemplo de dispositivo utilizado para ensaio de difusão (SHACKELFORD, 1988 apud LEITE, 2001) ............................................12

Figura 3-2 - Esquema ilustrativo do ensaio de coluna (modificado de DOMENICO \& SCHWARTZ, 1998). 13

Figura 3-3 - Perfil das duas células experimentais construídas no aterro de Rio das Ostras/RJ (modificado de RITTER et al., 2009). 15

Figura 3-4 - Perfis da difusão do cloreto no solo sob o "liner", obtidos com os dados experimentais e por simulação numérica (RITTER et al., 2009).

Figura 3-5 - Perfis da difusão do amônio no solo sob o "liner", obtidos com os dados experimentais e por simulação numérica (RITTER et al., 2009).

Figura 3-6 - Profundidades das amostras coletadas e perfil do subsolo sob a lagoa (FERRARI et al., 2010).

Figura 3-7 - Concentração dos íons sódio e cloreto na água intersticial do subsolo do local de disposição de resíduos de Sárnia após 12 anos de difusão (ROWE et al.,1995).

Figura 3-8 - Concentração total de metais no subsolo do local de disposição de resíduos de Sárnia após 16 anos de difusão (ROWE et al.,1995).

Figura 3-9 - Ensaio de permeabilidade em solo saprolítico com água e lixiviado (SOARES, 2012). .26

Figura 3-10 - Ensaios de adensamento com água e lixiviado (SOARES, 2012). 27

Figura 3-11 - Envoltórias de resistência do ensaios de cisalhamento na presença de:

(a) água; (b) lixiviado (SOARES, 2012). 27

Figura 4-1 - Fluxograma da investigação experimental de campo e de laboratório. .....30

Figura 4-2 - Mapeamento pedológico do subsolo da região de Botucatu (modificado de IBGE, 2012). .32 
Figura 4-3 - Vista regional e superior do empreendimento (fonte: modificado de Google Earth em 06.02.2011). .34

Figura 4-4 - Mapa potenciométrico da região. As setas de cor azul indicam a direção e o sentido do movimento das águas subterrâneas. .34

Figura 4-5 - Bloco indeformado retirado para ensaios de laboratório............................35

Figura 4-6 - Lagoa de acumulação de lixiviado sem impermeabilização. 36

Figura 4-7 - Locação dos perfis planejados para serem amostrados e locação dos perfis executados. .36

Figura 4-8 - Execução da amostragem de solo contaminado......................................37

Figura 4-9 - Amostras colocadas em estufa para remoção da umidade. 39

Figura 4-10 - Amostra de solo contaminado após moagem. .39

Figura 4-11 - Transferência do material preparado para os frascos digestores. .40

Figura 4-12 - Micro-ondas da fabricante Berghof e modelo Speedwave Four utilizado para o aquecimento das amostras com ácido.

Figura 4-13 - Balões volumétricos preenchidos com amostras de solos após digestão em micro-ondas e branco de análise.

Figura 4-14 - Espectrômetro de emissão atômica com plasma induzido (ICP-AES) marca Varian modelo 720-ES utilizado na determinação das concentrações das soluções digeridas. .43

Figura 4-15 - Frasco de Mariotte preenchido com água ao lado de corpo-de-prova em câmara do aparelho Tri-Flex. .48

Figura 4-16 - Frasco de Mariotte: (a) preenchido com lixiviado; (b) coberto com papel alumínio para evitar reações químicas pela incidência de luz no lixiviado. ...50

Figura 5-1 - Distribuição granulométrica do solo local típico. .53

Figura 5-2 - Curva de compactação obtida. .54

Figura 5-3 - Resultado do ensaio de difratometria de raios $X$ 56 
Figura 5-4 - Fases identificadas no difratograma de raio $\mathrm{X}$

Figura 5-5 - Minerais encontrados durante a realização da MEV (predominância de 1 e 2: $\mathrm{TiO} 2$ e Fe2O3; 3: Al2O3, $\mathrm{SiO} 2$ e Fe2O3; 4: Al2O3, $\mathrm{SiO} 2$ e Fe2O3; $5:$ $\mathrm{SiO} 2)$.

Figura 5-6 - Minerais encontrados durante a realização da MEV (predominância de 1: $\mathrm{SiO} 2$; 2: Al2O3, $\mathrm{SiO} 2$ e $\mathrm{Fe} 2 \mathrm{O} 3$; 3: $\mathrm{SiO} 2, \mathrm{Al} 2 \mathrm{O} 3$, e $\mathrm{Fe} 2 \mathrm{O} 3$; 4: $\mathrm{Fe} 2 \mathrm{O} 3$ e

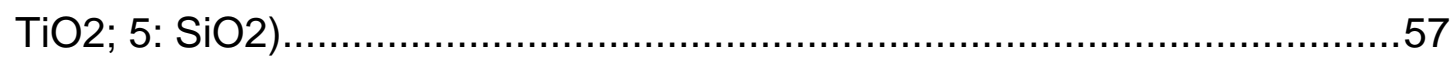

Figura 5-7 - Ensaio de permeabilidade à água do corpo-de-prova CP 01. ..................60

Figura 5-8 - Ensaio de permeabilidade à água do corpo-de-prova CP 03. ...................61

Figura 5-9 - Ensaio de permeabilidade à água do corpo-de-prova $05 . \ldots \ldots \ldots \ldots \ldots \ldots \ldots \ldots . . .61$

Figura 5-10 - Ensaio de permeabilidade à água do corpo-de-prova CP 06..................62

Figura 5-11 - Ensaio de permeabilidade ao lixiviado do corpo-de-prova CP 01............65

Figura 5-12 - Ensaio de permeabilidade ao lixiviado do corpo-de-prova CP 03.............65

Figura 5-13 - Ensaio de permeabilidade ao lixiviado do corpo-de-prova CP 05............66

Figura 5-14 Ensaio de permeabilidade ao lixiviado do corpo-de-prova CP 06..............66

Figura 5-15 - Concentrações do elemento arsênio durante os ensaios de coluna nos corpos-de-prova: (a) CP 05; (b) CP 06.

Figura 5-16 - Concentrações do elemento cádmio durante os ensaios de coluna nos corpos-de-prova: (a) CP 05; (b) CP 06..................................................

Figura 5-17 - Concentrações do elemento chumbo durante os ensaios de coluna nos corpos-de-prova: (a) CP 05; (b) CP 06...............................................71

Figura 5-18 - Concentrações do elemento cobre durante os ensaios de coluna nos corpos-de-prova: (a) CP 05; (b) CP 06.............................................. 71

Figura 5-19 - Concentrações do elemento cromo durante os ensaios de coluna nos corpos-de-prova: (a) CP 05; (b) CP 06................................................72 
Figura 5-20 - Concentrações do elemento ferro durante os ensaios de coluna nos corpos-de-prova: (a) CP 05; (b) CP 06................................................72

Figura 5-21 - Concentrações do elemento manganês durante os ensaios de coluna nos corpos-de-prova: (a) CP 05; (b) CP 06. .73

Figura 5-22 - Concentrações do elemento níquel durante os ensaios de coluna nos corpos-de-prova: (a) CP 05; (b) CP 06. .73

Figura 5-23 - Concentrações do elemento zinco durante os ensaios de coluna nos corpos-de-prova: (a) CP 05; (b) CP 06. .74

Figura 5-24 - Perfis de contaminação do chumbo no subsolo da lagoa não impermeabilizada. 79

Figura 5-25 - Perfis de contaminação do cobre no subsolo da lagoa não impermeabilizada. .79

Figura 5-26 - Perfis de contaminação do cromo no subsolo da lagoa não impermeabilizada.

Figura 5-27 - Perfis de contaminação do ferro no subsolo da lagoa não impermeabilizada. 80

Figura 5-28 - Perfis de contaminação do manganês no subsolo da lagoa não impermeabilizada. .81

Figura 5-29 - Perfis de contaminação do zinco no subsolo da lagoa não impermeabilizada. .81

Figura 5-30 - Perfis de contaminação do cloreto no subsolo da lagoa não impermeabilizada.

Figura 5-31 - Perfis de contaminação do carbono orgânico total no subsolo da lagoa não impermeabilizada.

Figura 5-32 - Perfis de contaminação do nitrogênio Kjeldahl total no subsolo da lagoa não impermeabilizada. 


\section{LISTA DE TABELAS}

Tabela 3-1 - Características mais prováveis do lixiviado de aterros brasileiros (SOUTO;

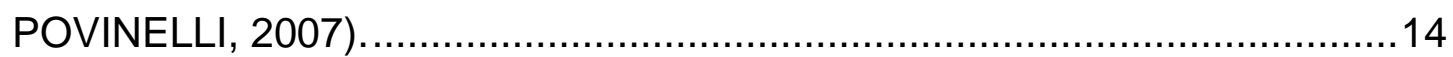

Tabela 3-2 - Caracterização do solo (RITTER et al., 2009).......................................16

Tabela 3-3 - Parâmetros de transporte do solo e da geomembrana de PEAD (VALADÃO, 2008 apud RITTER et al., 2009)..........................................16

Tabela 3-4 - Concentrações dos íons amônio e cloreto na água intersticial do solo do revestimento de fundo (RITTER et al., 2009)..........................................17

Tabela 3-5 - Concentração dos constituintes presentes no lixiviado gerado no aterro sanitário de São Carlos em diferentes anos (FERRARI et al., 2010)...........21

Tabela 3-6 - Concentração dos constituintes adsorvidos nas amostras de solo exumadas em mg/kg (FERRARl et al., 2010). .......................................22

Tabela 3-7 - Condutividade hidráulica à água e ao lixiviado (CORRÊA, 2001).............28

Tabela 4-1- Série histórica de dados meteorológicos do município de Botucatu

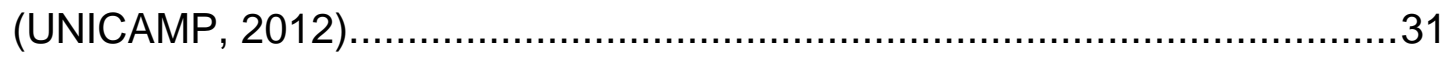

Tabela 4-2 - Gradiente hidráulico recomendado para ensaios de permeabilidade pela ASTM (1990).

Tabela 5-1 - Resultado da análise química semiquantitativa do solo..........................58

Tabela 5-2- Resultado das análises químicas do solo. ..........................................58

Tabela 5-3- Dados dos corpos-de-prova submetidos a ensaios de permeabilidade. ....60

Tabela 5-4 - Resumo dos ensaios de permeabilidade à água....................................62

Tabela 5-5 - Resumo dos ensaios de permeabilidade ao lixiviado.............................67

Tabela 5-6 - Composição química do lixiviado. ......................................................69

Tabela 5-7 - Concentrações dos elementos químicos nas amostras de solo (mg/Kg). .78 
Tabela 5-8 - Concentrações obtidas em Ferrari et al. (2010) e nas amostras estudas

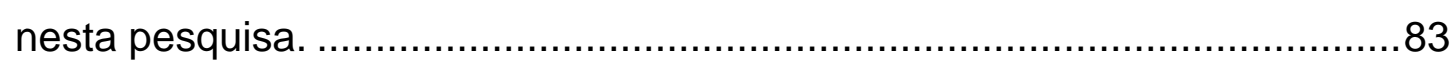

Tabela 5-9 - Valores orientadores para solos do estado de São Paulo (CETESB, 2005)

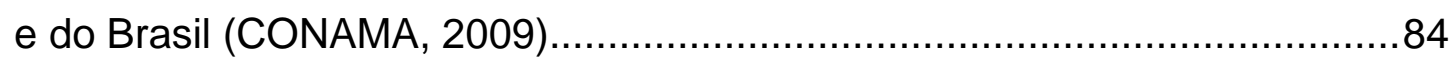

Tabela 5-10 - Concentrações de cloreto, COT e NKT nas amostras de solo $(\mathrm{mg} / \mathrm{Kg})$...86 Tabela 5-11 - Concentrações obtidas em Ferrari et al. (2010) e nas amostras estudas nesta pesquisa. 


\section{SUMÁRIO}

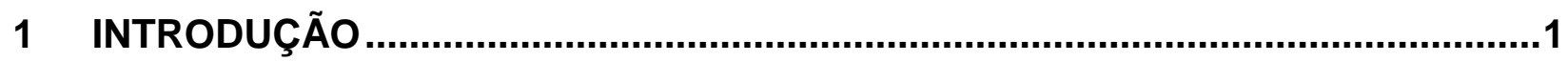

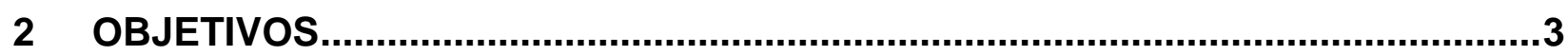

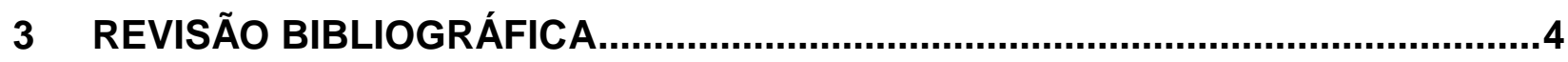

3.1 MECANISMOS DE TRANSPORTE DE SOLUTOS EM MEIOS POROSOS .............................

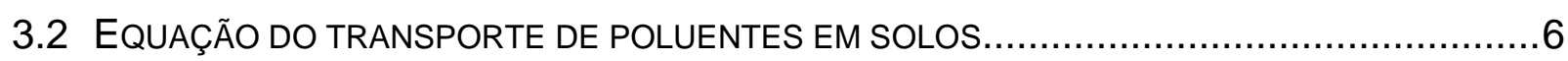

3.3 OBTENÇÃO DE PARÂMETROS POR MEIO DE ENSAIOS LABORATORIAIS ........................10

3.3.1 Ensaio de adsorção em batelada ........................................................10

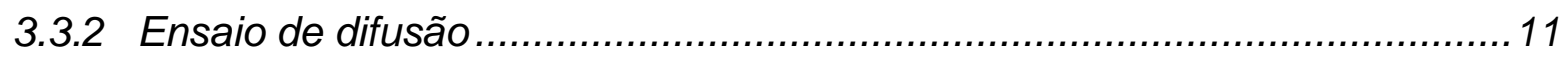

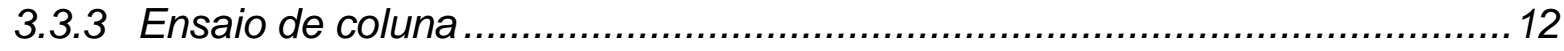

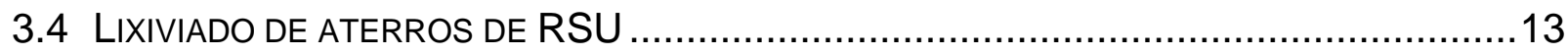

3.5 COMPATIBILIDADE ENTRE SOLO E LIXIVIADO DE ATERRO SANITÁRIO............................25

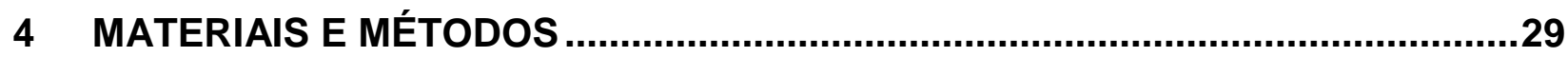

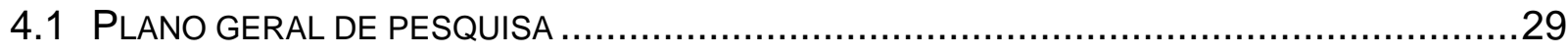

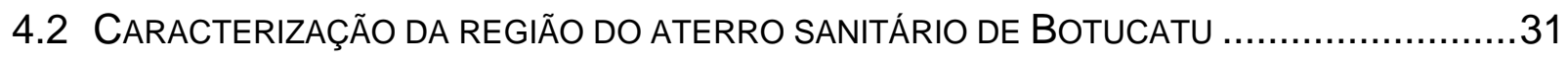

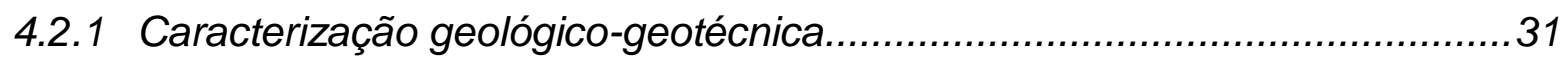

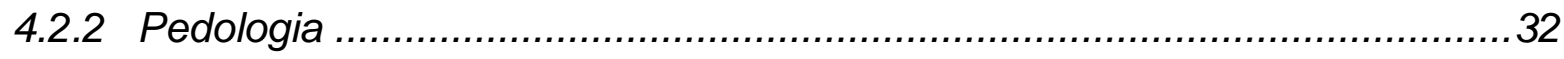

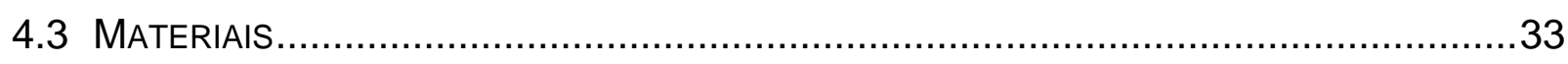

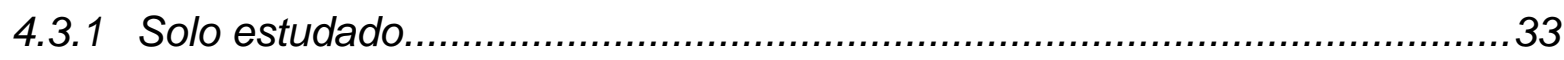

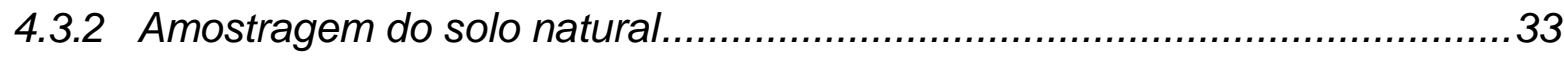

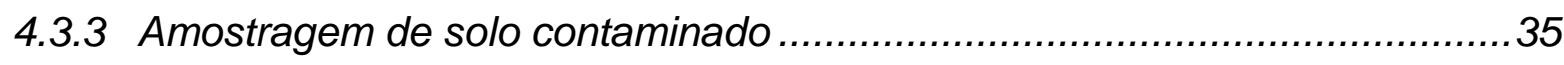

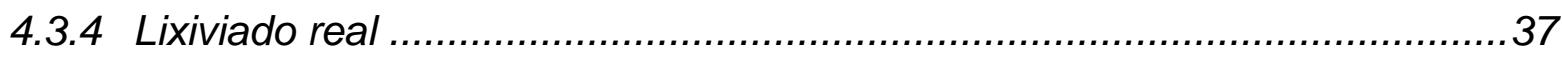

4.4 ANÁLISES QUÍMICAS DAS AMOSTRAS DE SOLO NATURAL, LODO E SOLO CONTAMINADO..38

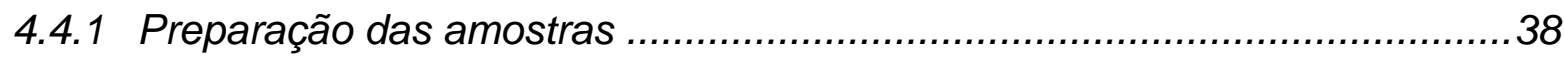

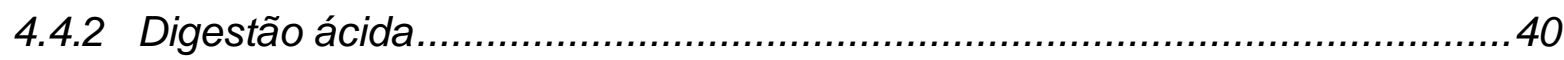

4.4.3 Avolumamento das amostras ..............................................................

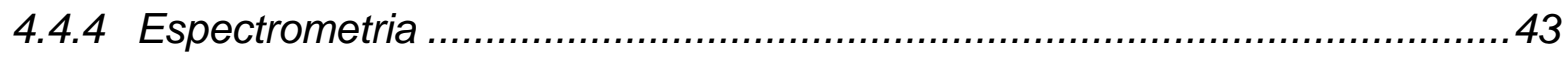

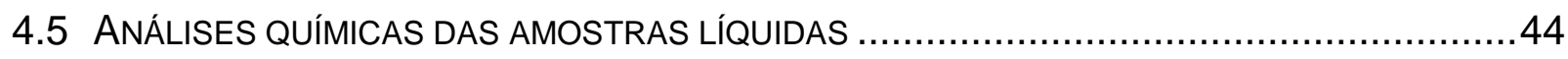


4.6 CARACTERIZAÇÃO GEOTÉCNICA, MINERALÓGICA E QUíMICA do SOLO NATURAL.............45

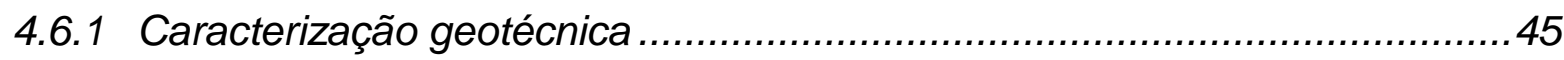

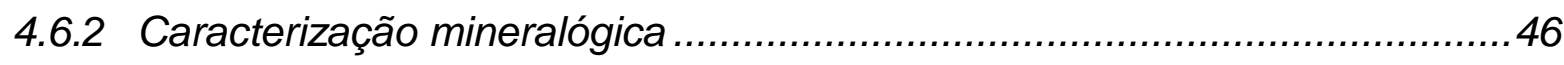

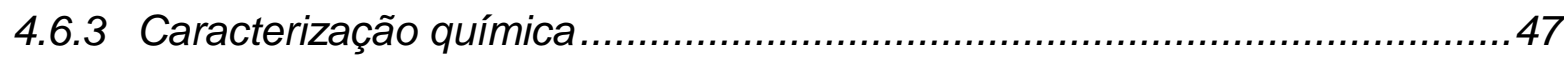

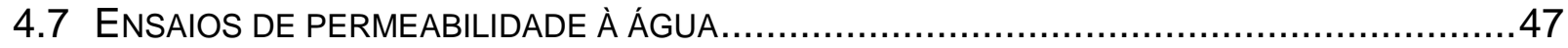

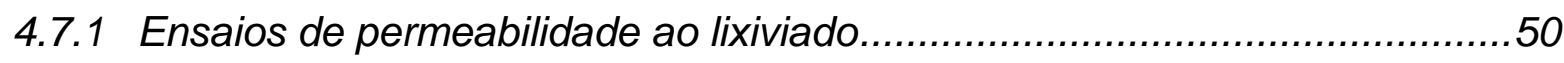

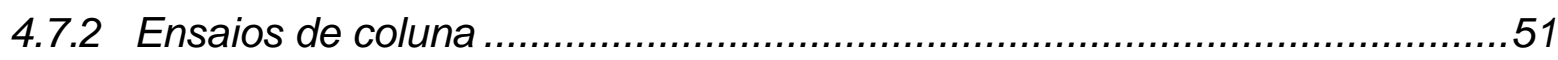

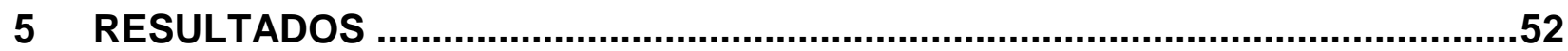

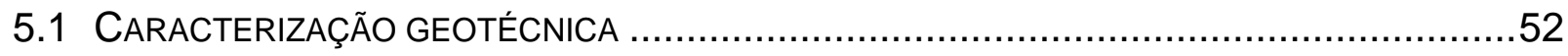

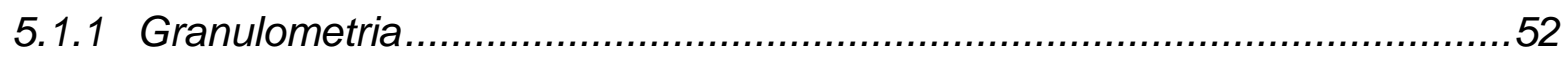

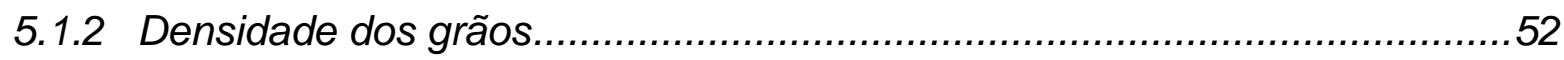

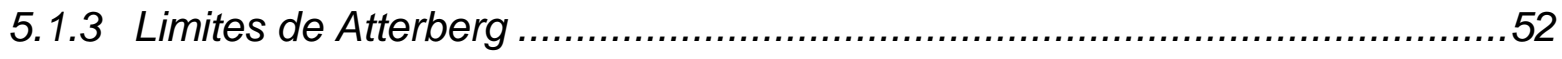

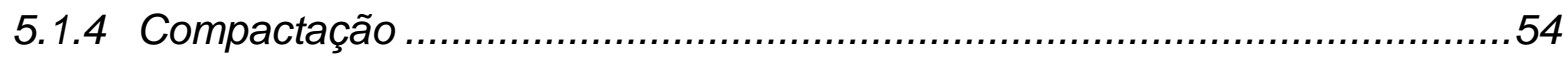

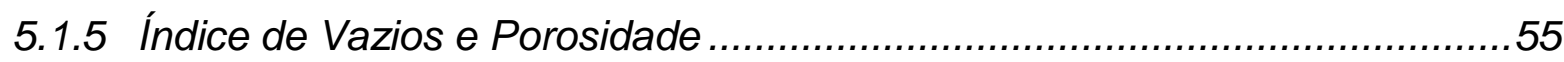

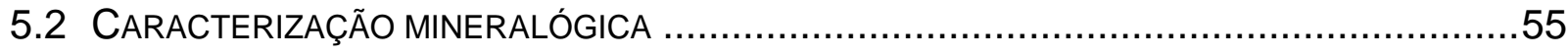

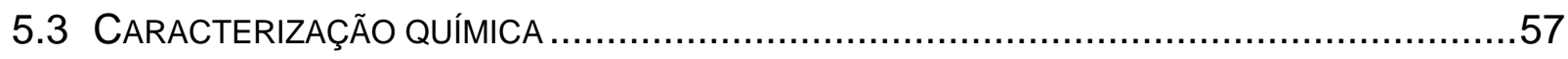

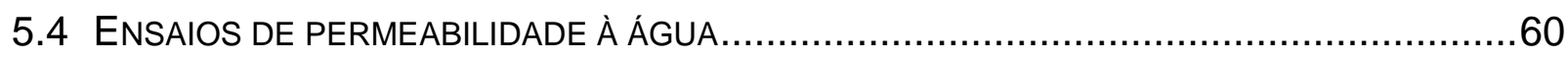

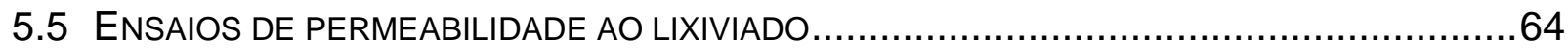

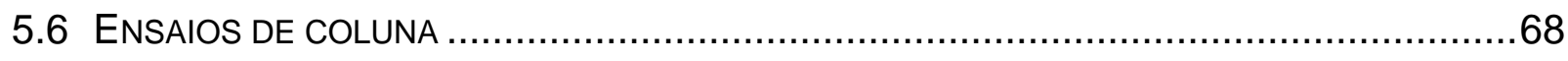

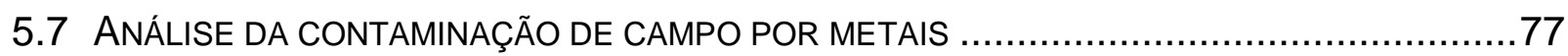

5.8 AnÁlise da CONTAMINAÇÃo de CAMPo POR Cloreto, CARBono Orgânico Total E

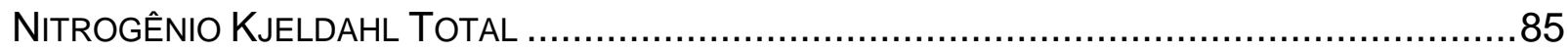

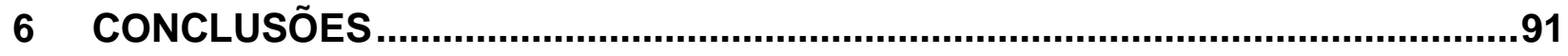

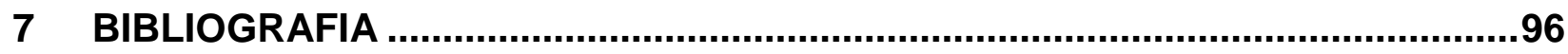




\section{INTRODUÇÃO}

Um dos principais potenciais impactos ambientais de aterros sanitários, a contaminação do subsolo, senão o mais grave entre os impactos desta modalidade de obra geotécnica, decorre da infiltração, no subsolo, do lixiviado produzido na massa de resíduos sólidos urbanos (RSU).

Os aterros sanitários propriamente ditos contam com um revestimento de fundo composto por camadas drenante e impermeabilizante, de maneira a evitar que haja escape descontrolado do lixiviado pela base do aterro. Além disso, contam com cobertura operacional e final, drenagem de biogás e de lixiviado, compactação dos resíduos, divisão em células e monitoramento geotécnico e ambiental. Os vazadouros ou lixões, por outro lado, são locais de disposição dos resíduos sem qualquer elemento de proteção ambiental. Os aterros controlados são todos aqueles em situação intermediária entre os aterros sanitários e vazadouros, apresentando geralmente compactação e cobertura dos resíduos.

De acordo com o levantamento da ABRELPE (2012), do total em massa de RSU gerados no país em 2011, foram destinados para aterros sanitários apenas $58 \%$; os $42 \%$ restantes foram dispostos em aterros controlados ou em vazadouros, os quais não possuem revestimento de fundo.

Em 2010 foi criado o marco legal para a gestão dos resíduos sólidos, através da lei federal n. ${ }^{\circ} 12.305$ (BRASIL, 2010a) e do decreto federal n. ${ }^{\circ} 7.404$ (BRASIL, 2010b), instituindo a Política Nacional de Resíduos Sólidos, a qual proíbe, a partir do ano de 2014, a disposição final ambientalmente inadequada dos resíduos sólidos, ou seja, em vazadouros ou aterros controlados. Até 2014 o país precisará eliminar os vazadouros e melhorar as condições de aterros que não tratam o lixiviado e os gases da decomposição dos resíduos, nem protegem o subsolo e as águas subterrâneas, o que corresponde à situação que ocorre em mais de 4.000 municípios brasileiros (IBGE, 2011).

Também no ano de 2010 foi criada a norma técnica NBR 15.849 - "Resíduos Sólidos Urbanos - Aterros sanitários de pequeno porte - Diretrizes para localização, projeto, implantação, operação e encerramento" (ABNT, 2010), a qual, visando contemplar a dificuldade de pequenos municípios disporem de recursos técnicos e 
financeiros suficientes para implantar as caras infraestrutura e operação de aterros sanitários, flexibilizou o projeto do revestimento de fundo sem suficiente embasamento técnico e científico.

A Companhia Ambiental do Estado de São Paulo (CETESB) tem requisitado, para o revestimento de fundo de aterros sanitários, a configuração exigida pela United States Environmental Protection Agency (USEPA, 1993) e amplamente aplicada internacionalmente: uma camada de solo argiloso compactada com espessura de $60 \mathrm{~cm}$ e condutividade hidráulica máxima de $1 \times 10^{-9} \mathrm{~m} / \mathrm{s}$ sob geomembrana de PEAD (polietileno de alta densidade) de 2,0 $\mathrm{mm}$ de espessura. Para os aterros de pequeno porte em municípios que gerem até $10 \mathrm{t} / \mathrm{dia}$, contudo, a CETESB aceita a construção de valas sem revestimento de fundo. A NBR 15.849 também permite, em certas condições hidrogeológicas e climáticas, que se prescinda da camada de argila compactada e da utilização de geomembrana de PEAD nos aterros sanitários de pequeno porte.

Neste trabalho foi selecionado para estudo o caso do aterro sanitário de Botucatu, localizado no município de mesmo nome no interior do estado de São Paulo. $O$ aterro de Botucatu operou por muitos anos como aterro controlado e recentemente passou por obras de recuperação para tornar-se um aterro sanitário. Até então, contava com lagoa de acumulação de lixiviado sem revestimento de fundo, ou seja, sem qualquer barreira para a infiltração do lixiviado no subsolo. Nesta pesquisa são utilizados dados de análise da contaminação do subsolo subjacente à lagoa (com medições de campo da ocorrência e distribuição espacial de poluentes no solo) e ensaios laboratoriais com amostras de solo local sem contaminação para avaliar a infiltração do lixiviado no subsolo. 


\section{OBJETIVOS}

O objetivo desta dissertação de mestrado é avaliar o transporte de poluentes de um lixiviado real de aterro sanitário em um solo tropical laterítico típico do estado de São Paulo, o qual constitui o subsolo do aterro de resíduos sólidos urbanos de Botucatu.

Neste aterro sanitário - o qual recentemente recebeu obras de recuperação para operar como um aterro sanitário - houve comprovadamente percolação do lixiviado pelo subsolo de uma lagoa de acumulação de lixiviado durante aproximadamente 15 anos.

Os poluentes investigados neste trabalho são: arsênio, cádmio, carbono orgânico total (COT), chumbo, cloreto, cobre, cromo, ferro, manganês, níquel, nitrogênio Kjeldahl total (NKT) e zinco.

A pesquisa objetiva também comparar dois métodos de avaliação de transporte de poluentes: ensaios laboratoriais e análise de dados da contaminação de campo. 


\section{REVISÃO BIBLIOGRÁFICA}

Os lixiviados de aterros sanitários e de aterros industriais, os esgotos sanitários, os efluentes industriais, os lodos de estações de tratamento de água e esgoto, os rejeitos de mineração, entre outros resíduos, apresentam em sua composição elementos e substâncias poluentes que podem ser dissolvidos em água e transportados como solutos através do subsolo.

\subsection{Mecanismos de transporte de solutos em meios porosos}

O transporte pelo subsolo de poluentes dissolvidos na água é estudado como transporte de massa de um soluto em meio poroso. Os principais mecanismos do transporte de um soluto em um meio poroso, os quais atuam simultaneamente, são: a advecção, a difusão, a dispersão mecânica, as reações químicas entre o soluto e os grãos do solo, e reações químicas do próprio soluto.

A advecção é o mecanismo pelo qual o soluto é carreado pela água em movimento mantendo a concentração constante do soluto na solução - a uma velocidade média $u$ igual a $v / n$, sendo $v$ a velocidade de Darcy e $n$ a porosidade do solo.

A difusão é o mecanismo pelo qual íons ou moléculas se movem devido a sua energia termo-cinética na direção do gradiente de concentração. Ocorre um deslocamento do soluto das regiões de maior para as de menor concentração. A difusão ocorre mesmo em situações sem fluxo e somente deixa de atuar em casos de gradientes de concentrações nulos.

A dispersão mecânica é um espalhamento em relação à direção do fluxo médio advectivo devido à variação de velocidade em magnitude e direção no espaço dos vazios. A dispersão é causada principalmente pela trajetória tortuosa das linhas de fluxo, a rugosidade da superfície dos grãos e a variação das dimensões dos vazios. O espalhamento ocorre tanto longitudinal quanto transversalmente à direção do fluxo advectivo médio.

Pode-se denominar dispersão hidrodinâmica ao efeito conjunto da difusão e da dispersão mecânica; ou seja, o espalhamento no nível macroscópico resultante de 
ambos os mecanismos. Alguns autores consideram artificial separar os mecanismos, uma vez que a dispersão mecânica induz gradientes de concentração que provocam a difusão (BOSCOV, 2008).

Na maioria dos problemas geoambientais, a advecção com dispersão mecânica é o principal processo de transporte, pelo qual a maior parte dos poluentes é distribuída através do solo e dos aquíferos. A difusão ganha relevância em situações de baixas velocidades, associadas a solos pouco permeáveis e baixos gradientes, o que é o caso das camadas de solo compactado de revestimento de fundo de aterros de resíduos.

São diversas as reações químicas e bioquímicas que podem alterar a concentração de poluentes que percolam em meios porosos, sendo as mais estudadas e significantes na geotecnia as reações de adsorção/desadsorção. A adsorção é um processo físico-químico pelo qual uma substância é acumulada numa interface entre fases. No caso de transporte de solutos em solos, a adsorção geralmente refere-se à acumulação de soluto na superfície das partículas sólidas do solo, ou seja, nos grãos. A adsorção física ocorre devido a forças eletrostáticas e, a adsorção química, a ligações químicas reais entre o soluto e as partículas sólidas do solo. As forças de atração da adsorção física envolvem energias de ligações inferiores às da adsorção química e são reversíveis.

A reversibilidade da adsorção é chamada de desadsorção ou dessorção, tratando-se da liberação de solutos anteriormente adsorvidos, quando a concentração afluente é reduzida, ou ainda, quando ocorre competição com outro soluto mais fortemente adsorvível, geralmente cátions de maior valência.

A atenuação de solutos poluentes decorre do fenômeno de adsorção e é objeto de estudo há muitos anos. É geralmente associada aos argilos-minerais, embora nos solos tropicais as frações silte e areia também contribuam para a capacidade de retenção de poluentes, como observado em Lange (2012) e em diversos trabalhos compilados em Boscov $(2010,2011)$.

Os argilos-minerais são a menor fração granulométrica dos solos, podendo ser considerados colóides: têm comportamento controlado por forças de superfície preponderando sobre as forças de massa, dimensões até $2 \mu \mathrm{m}$, elevada superfície 
específica e cargas elétricas superficiais decorrentes de imperfeições ou substituições iônicas no retículo cristalino. Os argilo-minerais têm carga elétrica superficial negativa, atraindo cátions e moléculas polares, como a água.

Os óxidos metálicos e a matéria orgânica presentes na fração argila (grãos de diâmetro igual ou inferior a $2 \mu \mathrm{m}$ ) são também responsáveis pela atividade química dos solos. Apresentam cargas reversíveis e, portanto, capacidade de atração de cátion e ânions (SPOSITO, 1989). Nos solos tropicais os óxidos metálicos também estão presentes nas frações silte e areia, explicando a contribuição dessas frações na capacidade de retenção de poluentes do solo.

\subsection{Equação do transporte de poluentes em solos}

A formulação teórica básica do transporte de poluentes em solos se refere ao transporte unidimensional de um soluto ideal dissolvido em água através de solo saturado, homogêneo e isotrópico, em condições de fluxo de água uniforme e permanente.

O fluxo advectivo é entendido como o fluxo de massa transportado pela velocidade da água com concentração constante, sendo representado pela seguinte equação:

$J_{a d v e c c ̧ a ̃ o}=c v=n c u$

sendo:

Jadvecção: fluxo de massa do soluto por advecção;

c: concentração do poluente na água do solo;

v: velocidade de percolação ou de Darcy da água em movimento;

$\mathrm{n}$ : porosidade do solo; e

u: velocidade específica ou de percolação

A difusão é representada matematicamente pela primeira Lei de Fick, a qual considera que a quantidade em massa de substância que migra por difusão, 
passando por uma seção transversal conhecida por unidade de tempo, é proporcional ao gradiente de concentração:

$J_{\text {difusão }}=-n D_{d} \frac{\partial c}{\partial z}$

sendo:

$J_{\text {difusão: }}$ fluxo de massa por difusão;

$\mathrm{D}_{\mathrm{d}}$ : coeficiente de difusão do poluente no solo; e

z: direção do fluxo de massa.

Pode-se observar que o mecanismo de difusão ocorre no sentido contrário ao do gradiente de concentrações, explicando o sinal negativo da Equação 2.

O mecanismo de dispersão mecânica é usualmente representado juntamente com a difusão, ou seja, através da dispersão hidrodinâmica, pela Lei de Fick (Equação 3), apesar da dispersão mecânica não ser proporcional ao gradiente de concentrações (Equação 4).

$\mathrm{J}_{\text {dispersão hidrodinâmica }}=-\mathrm{nD}_{\mathrm{dh}} \frac{\partial \mathrm{c}}{\partial \mathrm{z}}$

$D_{d h}=D_{d}+D_{d m}=D_{d}+\propto u=D_{d}+\propto \frac{v}{n}$

sendo:

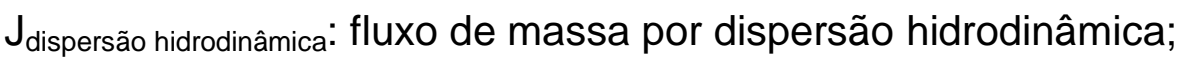

$\mathrm{D}_{\mathrm{dh}}$ : coeficiente de dispersão hidrodinâmica;

$\mathrm{D}_{\mathrm{dm}}$ : coeficiente de dispersão mecânica; e

$\alpha$ : dispersividade dinâmica ou dispersividade (característica do meio poroso).

A adsorção pode ser descrita matematicamente pelas isotermas de adsorção, que representam a massa de soluto adsorvida por massa seca de adsorvente em função da concentração do soluto na fase líquida quando em equilíbrio químico. 
A isoterma mais simples, e também a mais utilizada, é a linear, que admite a proporcionalidade direta, à temperatura constante:

$S=K_{d} C$

sendo:

S: concentração de soluto na fase adsorvida (adsorvente);

$\mathrm{K}_{\mathrm{d}}$ : coeficiente de adsorção (ou de distribuição); e

C: concentração de equilíbrio do soluto na solução.

A quantidade de soluto adsorvido no material adsorvente cresce com o aumento da concentração na solução, mas não ilimitadamente, uma vez que as partículas de argilo-minerais, responsáveis pela maior parcela da adsorção nos solos, possuem capacidade finita de adsorção.

Outras isotermas muito utilizadas em Geotecnia Ambiental são as de Freundlich (Equação 6) e de Langmuir (Equação 7), as quais podem ser também representadas pelo modelo geral de adsorção não linear (Equação 8).

$S=K_{f} C^{\varepsilon}$

sendo:

$\mathrm{K}_{\mathrm{f}}$ e $\varepsilon$ : coeficientes empíricos da isoterma de Freundlich.

$S=\frac{Q^{0} b C}{1+b C}$

sendo:

Q: número de moles de soluto adsorvido por unidade de massa do adsorvente ao formar uma monocamada na superfície (capacidade máxima de adsorção do adsorvente); e

b: constante relacionada à energia da adsorção.

$S=\frac{K C^{\beta}}{1+n C^{\beta}}$ 
sendo:

$\mathrm{k}, \beta$ e $\eta$ : coeficientes empíricos da isoterma geral para adsorção não linear.

A Equação 8 é chamada de modelo geral, pois para $\beta=1$, a equação equivale à de Langmuir e, para $\eta=0$, à de Freundlich.

A adsorção é geralmente considerada nos modelos de transporte de poluentes como instantânea e reversível, embora se despenda certo tempo para que seja atingido o equilíbrio na adsorção; ademais, o modelo linear é questionável, tanto devido á hipótese de relação linear entre concentração adsorvida e concentração dissolvida, como pelo fato de que há um limite máximo de adsorção pelos solos; mesmo assim, a hipótese de adsorção imediata, reversível e linear é amplamente utilizada devido à simplicidade do tratamento matemático de tal modelagem (BOSCOV, 2008).

A equação de transporte de poluentes em solo homogêneo, isotrópico, saturado e com fluxo permanente, uniforme e unidimensional de água é expressa por:

$\frac{\partial c}{\partial t}=D_{d h} \frac{\partial^{2} c}{\partial z^{2}}-u \frac{\partial c}{\partial z} \pm \delta$

A primeira parcela da igualdade da direita representa o fluxo por dispersão hidrodinâmica, a segunda o fluxo advectivo e a última $( \pm \delta)$ as reações químicas e bioquímicas, que podem ser fontes ou sorvedouros.

Considerando-se como única reação química a adsorção linear instantânea e reversível, e realizando as substituições necessárias:

$\left(1+\frac{\rho K_{d}}{n}\right) \frac{\partial c}{\partial t}=D_{d h} \frac{\partial^{2} c}{\partial z^{2}}-u \frac{\partial z}{\partial z}$

O termo $1+\frac{\rho K_{d}}{n}$ é denominado fator de retardamento e a Equação (10) pode ser reescrita como:

$R_{d} \frac{\partial c}{\partial t}=D_{d h} \frac{\partial^{2} c}{\partial z^{2}}-u \frac{\partial z}{\partial z}$ 
O fator de retardamento representa a relação entre a velocidade de percolação u e a velocidade do centro de massa de soluto.

A adsorção, portanto, acarreta em uma diminuição da velocidade de espalhamento de soluto em relação à velocidade advectiva. Quando a adsorção é nula, o fator de retardamento é igual a 1, ou seja, praticamente não ocorre diminuição da velocidade de espalhamento do centro de massa do soluto em relação à velocidade advectiva. Elevados fatores de retardamento praticamente imobilizam o soluto no solo.

\subsection{Obtenção de parâmetros por meio de ensaios laboratoriais}

Os ensaios laboratoriais mais difundidos para a determinação dos parâmetros de transporte de poluentes são os ensaios de adsorção em batelada (batch tests), de difusão e de coluna.

\subsubsection{Ensaio de adsorção em batelada}

Ensaios em batelada, também conhecidos por batch tests, são utilizados para determinar parâmetros de adsorção.

Neste ensaio, uma solução aquosa de composição e concentração conhecidas é misturada a uma massa de adsorvente por um período de tempo determinado até que seja atingido o equilíbrio químico, isto é, a situação em que as concentrações de soluto na fase líquida (massa de soluto dividida por volume de solução) e na fase sólida (massa de soluto adsorvido dividida por massa seca de adsorvente) permanecem constantes ao longo do tempo. Embora a adsorção seja considerada imediata, observa-se que no início do ensaio a massa adsorvida aumenta com o tempo, ao passo que a massa dissolvida na fase líquida decresce, até que seja atingida a constância de distribuição nas fases líquida e sólida. No ensaio, considera-se que o tempo de equilíbrio químico é atingido quando uma diferença igual ou inferior a $5 \%$ na concentração da fase líquida seja verificada em um intervalo de 24 horas (USEPA, 1992).

A seguir, a solução é separada do adsorvente, por centrifugação ou filtração, e analisada quimicamente para determinação da mudança na concentração de soluto. 
A quantidade de soluto adsorvida pelo adsorvente é, por hipótese, a diferença entre as concentrações inicial e final de soluto, multiplicada pelo volume da solução.

Geralmente são utilizadas triplicatas. Adicionalmente, utiliza-se sempre um ensaio "branco" para cada determinação. No frasco "branco" coloca-se a amostra de solução sem adsorvente e procede-se ao ensaio normalmente, em todas as suas etapas: mistura, agitação até ser atingido o tempo de equilíbrio, separação de fases por centrifugação ou filtração, e análise química da fase líquida após o equilíbrio. A diferença entre as concentrações inicial e final no frasco "branco" deveria ser nula. A alteração da concentração do soluto pode indicar que o frasco utilizado é inadequado (está adsorvendo o soluto ou liberando alguma espécie química na solução), ou que há inadequação no procedimento experimental.

\subsubsection{Ensaio de difusão}

O ensaio de difusão é utilizado para determinação do coeficiente de difusão de um poluente no solo.

Neste ensaio, o corpo-de-prova de solo é saturado por fluxo d'água ou por capilaridade. A seguir, o mesmo é colocado em contato com uma solução aquosa de composição e concentração conhecidas colocada em um reservatório sobre o corpode-prova, sem gradiente hidráulico, ou seja, não há movimento da solução. O soluto penetra no corpo-de-prova por difusão, uma vez que a concentração é maior na solução do reservatório do que no fluido intersticial do solo. A concentração da solução do reservatório é monitorada em intervalos de tempos pré-determinados.

Um esquema ilustrativo de um dos primeiros equipamentos de ensaio de difusão é apresentado na Figura 3-1, destacando-se o reservatório com a solução, a célula com o corpo-de-prova, o sistema de monitoramento do volume da solução no reservatório e o tubo para amostragem da solução.

Depois de finalizado o ensaio, o corpo-de-prova é extrudado da célula de difusão e dividido em fatias de igual espessura. Em cada fatia a água intersticial é extraída e são determinadas as concentrações dos elementos estudados. 


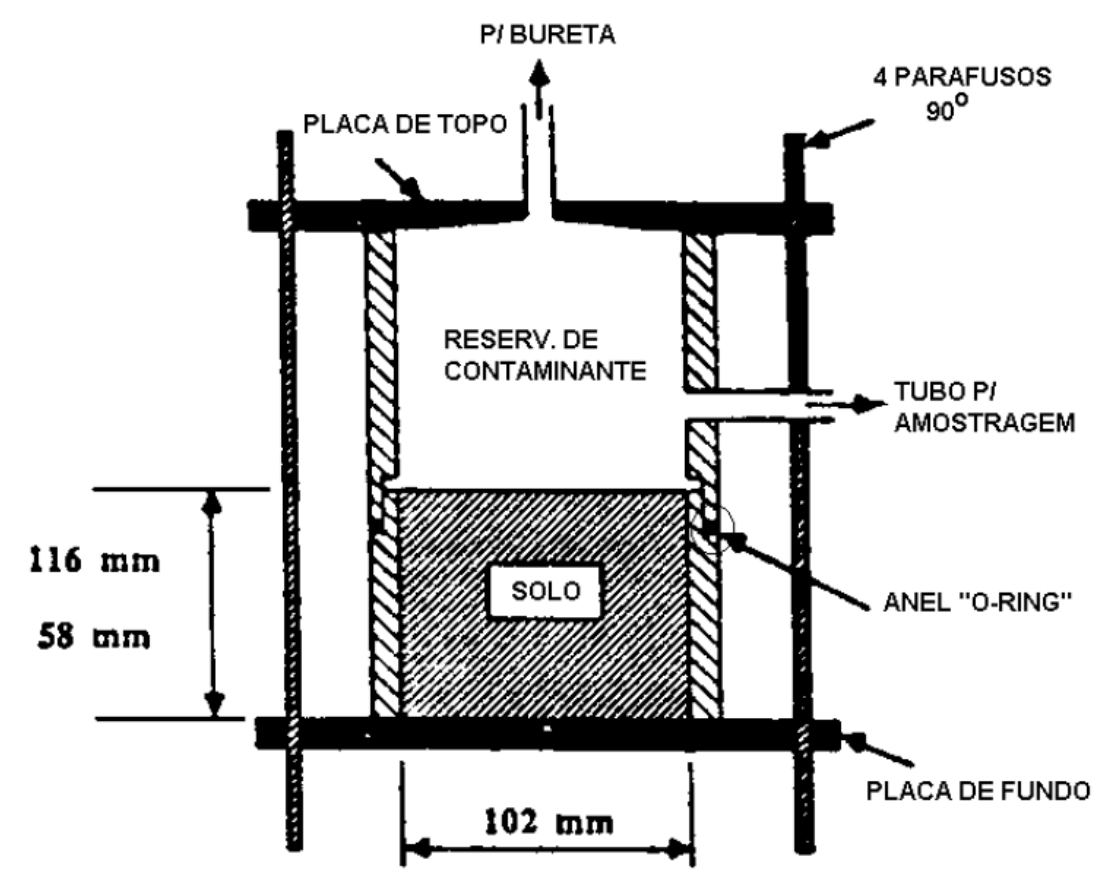

Figura 3-1 - Exemplo de dispositivo utilizado para ensaio de difusão (SHACKELFORD, 1988 apud LEITE, 2001)

\subsubsection{Ensaio de coluna}

O ensaio de dispersão ou coluna é geralmente realizado para a determinação do coeficiente de dispersão hidrodinâmica e do fator de retardamento.

O ensaio de coluna se inicia como um ensaio de permeabilidade convencional com carga hidráulica total constante. Após a passagem de um volume de água igual a dois volumes de vazios do corpo-de-prova, ou após a regularização da vazão efluente, substitui-se a alimentação de água por uma solução aquosa de composição e concentração conhecidas $\left(\mathrm{c}_{0}\right)$, mantendo-se o gradiente hidráulico aplicado e a percolação ininterrupta. Monitora-se a concentração efluente (c) ao longo do tempo, até que esta atinja o valor da concentração da solução aplicada ao corpo-de-prova (BOSCOV, 2008).

Os resultados dos ensaios de coluna são expressos através da relação $c / c_{0}$ em função do tempo ou do volume percolado (geralmente expresso em volumes de vazios do corpo-de-prova).

A representação gráfica da relação $\mathrm{c} / \mathrm{c}_{0}$ em função do tempo ou do volume percolado para a distância $x$ igual ao comprimento $L$ da coluna $(x=L)$ é chamada de 
curva de chegada ou breakthrough curve, ilustrada esquematicamente na Figura 3-2.
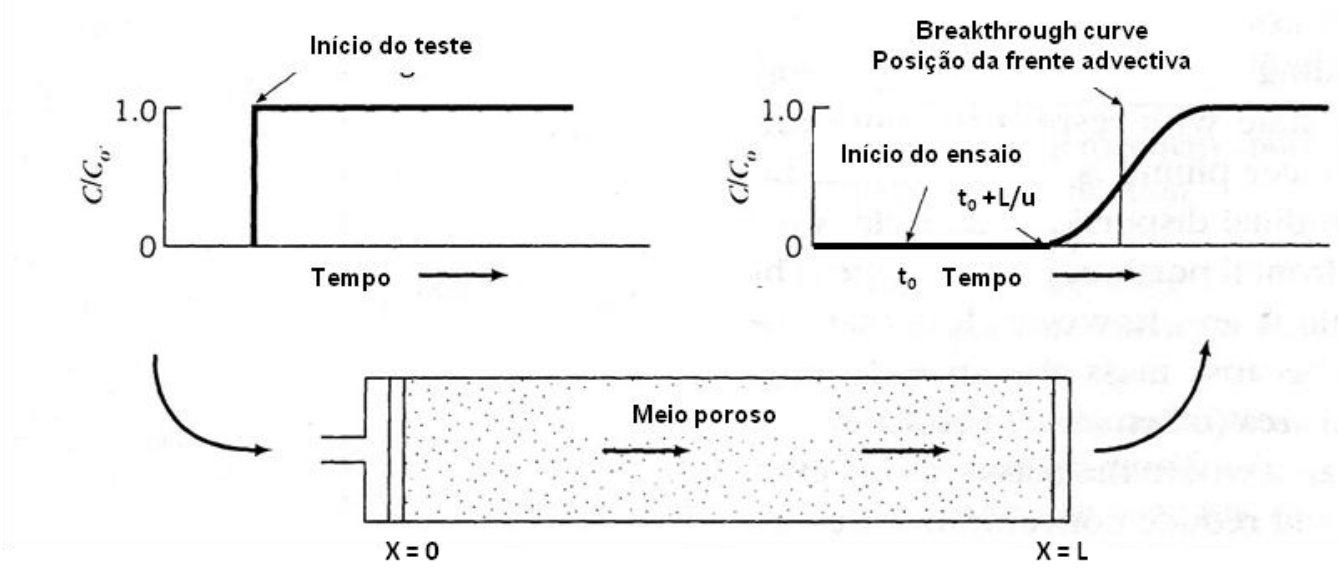

Figura 3-2 - Esquema ilustrativo do ensaio de coluna (modificado de DOMENICO \& SCHWARTZ, 1998).

Iniciando-se a alimentação do corpo-de-prova com a solução de concentração $\mathrm{c}_{0}$ no instante $t_{0}$, após certo tempo a relação $c / c_{0}$ passa a aumentar progressivamente até atingir o valor unitário. A frente advectiva atingiria a extremidade oposta do corpo-deprova (efluente) após o tempo $t_{0}+\mathrm{L} / \mathrm{u}$, sendo $\mathrm{L}$ o comprimento do corpo-de-prova e $u$ a velocidade de percolação; contudo, devido à dispersão hidrodinâmica, algumas partículas de soluto chegam antes e outras depois.

Sendo o soluto reativo, a adsorção retarda a frente, de modo que o centro de massa de soluto se move com velocidade $u / R_{d}$, sendo $R_{d} \circ$ fator de retardamento. A breakthrough curve se desloca, portanto, para a direita no eixo do tempo ou volume percolado.

\subsection{Lixiviado de aterros de RSU}

O lixiviado de aterros sanitários é o líquido gerado pela infiltração de águas de chuva na massa de resíduos, bem como pela mistura dos líquidos infiltrados com os produzidos pela degradação dos resíduos. A fase solvente dos lixiviados é majoritariamente proveniente da contribuição das águas pluviais; já os solutos (poluentes) se originam da degradação da massa de resíduos lixiviada pelas águas 
pluviais incidentes. O lixiviado de aterros sanitários é também denominado chorume ou percolado.

É grande a variabilidade dos constituintes dos lixiviados e suas respectivas concentrações, devido aos fatores precipitação, composição físico-química e gravimétrica dos resíduos, operação do local de destinação final (materiais e qualidade das coberturas diária e final, drenagem de águas pluviais), entre outros.

Souto e Povinelli (2007) apresentaram dados disponíveis da composição dos lixiviados de 25 aterros brasileiros, os quais estão apresentados na Tabela 3-1.

Tabela 3-1 - Características mais prováveis do lixiviado de aterros brasileiros (SOUTO; POVINELLI, 2007).

\begin{tabular}{|c|c|c|c|}
\hline Variável & Faixa máxima & Faixa mais provável & $\begin{array}{c}\text { FVM } \\
\text { P }\end{array}$ \\
\hline $\mathrm{pH}$ & $5,7-8,6$ & $7,2-8,6$ & $78 \%$ \\
\hline Alcalinidade total $\left(\mathrm{mg} / \mathrm{L}\right.$ de $\left.\mathrm{CaCO}_{3}\right)$ & $750-11400$ & $750-7100$ & $69 \%$ \\
\hline Dureza $\left(\mathrm{mg} / \mathrm{L}\right.$ de $\left.\mathrm{CaCO}_{3}\right)$ & $95-3100$ & $95-2100$ & $81 \%$ \\
\hline Condutividade $(\mu \mathrm{S} / \mathrm{cm})$ & $2950-25000$ & $2950-17660$ & $77 \%$ \\
\hline $\mathrm{DBO}(\mathrm{mg} / \mathrm{L})$ & $<20-30000$ & $<20-8600$ & $75 \%$ \\
\hline $\mathrm{DQO}(\mathrm{mg} / \mathrm{L})$ & $190-80000$ & $190-22300$ & $83 \%$ \\
\hline Óleos e Graxas (mg/L) & $10-480$ & $10-170$ & $63 \%$ \\
\hline Fenóis $\left(\mathrm{mg} / \mathrm{L}\right.$ de $\left.\mathrm{C}_{6} \mathrm{H}_{5} \mathrm{OH}\right)$ & $0,9-9,9$ & $0,9-4,0$ & $58 \%$ \\
\hline NTK (mg/L) & $80-3100$ & não há & - \\
\hline N-amoniacal (mg/L) & $0,4-3000$ & $0,4-1800$ & $72 \%$ \\
\hline N-orgânico (mg/L) & $5-1200$ & $400-1200$ & $80 \%$ \\
\hline $\mathrm{N}$-nitrito $(\mathrm{mg} / \mathrm{L})$ & $0-50$ & $0-15$ & $69 \%$ \\
\hline $\mathrm{N}$-nitrato $(\mathrm{mg} / \mathrm{L})$ & $0-11$ & $0-3,5$ & $69 \%$ \\
\hline P-total $(\mathrm{mg} / \mathrm{L})$ & $0,1-40$ & $0,1-15$ & $63 \%$ \\
\hline Sulfeto $(\mathrm{mg} / \mathrm{L})$ & $0-35$ & $0-10$ & $78 \%$ \\
\hline Sulfato $(\mathrm{mg} / \mathrm{L})$ & $0-5400$ & $0-1800$ & $77 \%$ \\
\hline Cloreto $(\mathrm{mg} / \mathrm{L})$ & $500-5200$ & $500-3000$ & $72 \%$ \\
\hline Sólidos totais $(\mathrm{mg} / \mathrm{L})$ & $3200-21900$ & 3200 a 14400 & $79 \%$ \\
\hline Sólidos totais voláteis $(\mathrm{mg} / \mathrm{L})$ & $630-20000$ & $630-5000$ & $60 \%$ \\
\hline Sólidos totais fixos $(\mathrm{mg} / \mathrm{L})$ & $2100-14500$ & $2100-8300$ & $74 \%$ \\
\hline Sólidos suspensos totais $(\mathrm{mg} / \mathrm{L})$ & $5-2800$ & $5-700$ & $68 \%$ \\
\hline Sólidos suspensos voláteis $(\mathrm{mg} / \mathrm{L})$ & $5-530$ & $5-200$ & $62 \%$ \\
\hline Ferro $(\mathrm{mg} / \mathrm{L})$ & $0,01-260$ & $0,01-65$ & $67 \%$ \\
\hline Manganês (mg/L) & $0,04-2,6$ & $0,04-2,0$ & $79 \%$ \\
\hline Cobre $(\mathrm{mg} / \mathrm{L})$ & $0,005-0,6$ & $0,05-0,15$ & $61 \%$ \\
\hline Níquel (mg/L) & $0,03-1,1$ & $0,03-0,5$ & $71 \%$ \\
\hline Cromo (mg/L) & $0,003-0,8$ & $0,003-0,5$ & $89 \%$ \\
\hline Cádmio (mg/L) & $0-0,26$ & $0-0,065$ & $67 \%$ \\
\hline Chumbo (mg/L) & $0,01-2,8$ & $0,01-0,5$ & $64 \%$ \\
\hline Zinco $(\mathrm{mg} / \mathrm{L})$ & $0,01-8,0$ & $0,01-1,5$ & $70 \%$ \\
\hline
\end{tabular}

FVMP: freqüência de ocorrência dos valores mais prováveis 
Alguns estudos, nos últimos anos, trouxeram a contribuição de experimentos e avaliação de contaminações de campo por lixiviado de aterro sanitário.

Ritter et al. (2009) construíram duas células experimentais no aterro sanitário de Rio das Ostras/RJ (Figura 3-3). A célula 1, cujo revestimento de fundo era constituído apenas por uma camada de solo compactado de $90 \mathrm{~cm}$ ("liner"), foi preenchida com 4 metros de altura de RSU, totalizando $800 \mathrm{~m}^{3}$ de resíduos. A célula 2, cujo revestimento de fundo era constituído por uma geomembrana de PEAD com $2 \mathrm{~mm}$ de espessura sobre uma camada de solo compactado de $90 \mathrm{~cm}$ de espessura, recebeu 3 metros de altura de RSU, correspondendo a $600 \mathrm{~m}^{3}$ de resíduos. Para proteger de cortes e furos a geomembrana que revestia a camada de $90 \mathrm{~cm}$ do fundo da célula 2, foi lançada sobre a geomembrana uma camada de 15 $\mathrm{cm}$ de espessura de solo (em aterros sanitários é usual e importante utilizar uma camada de proteção mecânica para proteção da geomembrana, como solo ou geotêxtil).
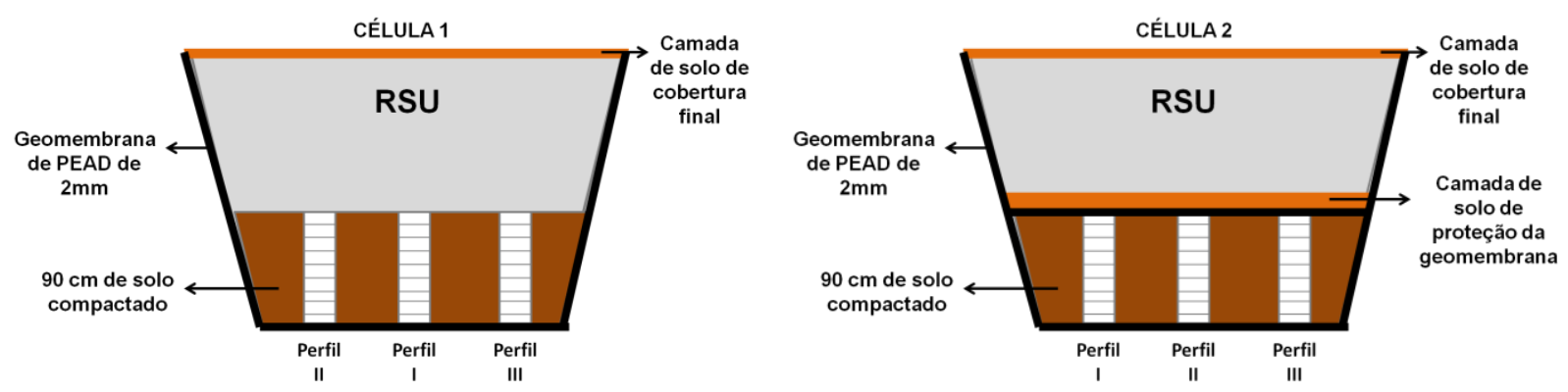

Figura 3-3 - Perfil das duas células experimentais construídas no aterro de Rio das Ostras/RJ (modificado de RITTER et al., 2009).

Como cobertura final dos resíduos, as células foram revestidas com uma camada de solo compactado. Antes da construção do revestimento de fundo das células, o terreno local foi também revestido por uma geomembrana de PEAD para evitar que o experimento contaminasse o subsolo.

Passados 26 meses após a construção das células, os resíduos foram removidos e amostras de solo do revestimento de fundo foram retiradas ao longo dos $90 \mathrm{~cm}$ de espessura, em três diferentes perfis sob cada célula, conforme apresentado na Figura 3-3. 
As características do solo local estão apresentadas na Tabela 3-2. O solo foi descrito com uma argila arenosa, contendo $37 \%$ de grãos de argila. $\mathrm{O}$ mineral predominante na fração argila é uma caulinita com capacidade de troca catiônica de $2,9 \mathrm{cmol} / \mathrm{kg}$ e o pH medido do solo foi de 6,2.

Tabela 3-2 - Caracterização do solo (RITTER et al., 2009).

\begin{tabular}{|l|c|}
\hline Densidade dos grãos & 26,60 \\
\hline Limite de liquidez (\%) & 55 \\
\hline Limite de plasticidade (\%) & 33 \\
\hline Índice de plasticidade $(\%)$ & 22 \\
\hline Fração argila $(<5 \mu \mathrm{m})(\%)$ & 37 \\
\hline Massa específica aparente seca $\left(\mathrm{g} / \mathrm{cm}^{3}\right)$ & 1,651 \\
\hline Porosidade & 0,42 \\
\hline Umidade ótima $(\%)$ & 20,9 \\
\hline
\end{tabular}

Batch tests foram executados em laboratório para medir o parâmetro de sorção do solo, $\mathrm{K}_{\mathrm{d}}$, e para medir os coeficientes de difusão dos íons $\mathrm{NH}_{4}{ }^{+}$e $\mathrm{Cl}^{-}$para o solo $\left(\mathrm{D}_{\mathrm{e}}\right)$ e geomembrana $\left(D_{g}\right)$, com o auxílio de um software de transporte de massa de contaminantes, o Multi-phase Heat and Mass Transfer Programa (MPHMTP). Os parâmetros obtidos estão apresentados na Tabela 3-3. A sorção de cloreto foi nula. Os coeficientes de difusão com geomembrana foram cerca de 1400 vezes menores para o íon cloreto e 10.000 vezes menores para o íon amônio, comparando com o solo.

Tabela 3-3 - Parâmetros de transporte do solo e da geomembrana de PEAD (VALADÃO, 2008 apud RITTER et al., 2009).

\begin{tabular}{|c|c|c|c|}
\hline Íon & $\begin{array}{c}\text { Parâmetro de sorção } \\
\left(\mathbf{(}_{\mathbf{d}}\right)\end{array}$ & $\begin{array}{c}\text { Coeficiente de difusão } \\
\text { do solo }\left(\mathbf{D}_{\mathbf{e}}\right)\end{array}$ & $\begin{array}{c}\text { Coeficiente de difusão } \\
\text { da geomembrana }\left(\mathbf{D}_{\mathbf{g}}\right)\end{array}$ \\
\hline $\mathbf{N H}_{4}{ }^{+}$ & $1,5 \mathrm{~cm}^{3} / \mathrm{g}$ & $0,085 \mathrm{~m}^{2} / \mathrm{ano}$ & $8,5 \times 10^{-6} \mathrm{~m}^{2} / \mathrm{ano}$ \\
\hline $\mathrm{Cl}^{-}$ & 0 & $0,065 \mathrm{~m}^{2} / \mathrm{ano}$ & $45,5 \times 10^{-6} \mathrm{~m}^{2} / \mathrm{ano}$ \\
\hline
\end{tabular}

As concentrações pontuais obtidas na água intersticial do solo compactado de cada célula experimental estão apresentadas na Tabela 3-4. I, II e III referem-se aos perfis amostrados de cada célula, conforme pode ser visualizados na Figura 3-3. 
Tabela 3-4 - Concentrações dos íons amônio e cloreto na água intersticial do solo do revestimento de fundo (RITTER et al., 2009).

\begin{tabular}{|c|c|c|c|c|c|c|c|c|c|c|c|c|}
\hline \multirow{3}{*}{$\begin{array}{l}\text { Profundidade } \\
\text { (m) }\end{array}$} & \multicolumn{6}{|c|}{ Célula 1} & \multicolumn{6}{|c|}{ Célula 2} \\
\hline & \multicolumn{3}{|c|}{ Cloreto (mg/L) } & \multicolumn{3}{|c|}{$\begin{array}{l}\text { Amônio } \\
\text { (mg/L) }\end{array}$} & \multicolumn{3}{|c|}{ Cloreto (mg/L) } & \multicolumn{3}{|c|}{$\begin{array}{c}\text { Amônio } \\
\text { (mq/L) }\end{array}$} \\
\hline & I & II & III & 1 & II & III & I & II & III & I & II & III \\
\hline 0,05 & 679 & 857 & 2812 & 228 & 18 & 18 & 65 & 98 & 70 & 16 & 19 & 19 \\
\hline 0,15 & 1037 & 361 & 2400 & 71 & 14 & 17 & 85 & 116 & 68 & 19 & 19 & 17 \\
\hline 0,25 & - & 164 & 1821 & - & 145 & 39 & 53 & 63 & 133 & 19 & 17 & 21 \\
\hline 0,35 & 842 & 965 & 161 & 74 & 39 & 7 & 75 & 67 & - & 27 & 14 & - \\
\hline 0,45 & 1030 & 889 & 90 & 159 & 29 & 10 & 101 & 71 & - & 57 & 12 & - \\
\hline 0,55 & 290 & 803 & 67 & 131 & 204 & 12 & 117 & 100 & - & 16 & 15 & - \\
\hline 0,65 & - & 1201 & 174 & - & 18 & 10 & 272 & 86 & - & 45 & 13 & - \\
\hline 0,75 & - & 260 & 61 & - & 170 & 25 & - & - & - & - & - & - \\
\hline 0,85 & - & - & 31 & - & - & 69 & - & - & - & - & - & - \\
\hline Background & \multicolumn{3}{|c|}{5,4} & \multicolumn{3}{|c|}{2,2} & \multicolumn{3}{|c|}{5,4} & \multicolumn{3}{|c|}{2,2} \\
\hline Lixiviado & \multicolumn{3}{|c|}{1178} & \multicolumn{3}{|c|}{414} & \multicolumn{3}{|c|}{1178} & \multicolumn{3}{|c|}{414} \\
\hline
\end{tabular}

Foram realizadas simulações numéricas considerando apenas a difusão nos $90 \mathrm{~cm}$ de solo compactado, em ambas as células, para o período de 26 meses em que ambas operaram. Na simulação, considerou-se uma coluna de 1 metro de lixiviado, com base na observação de campo quando da desmobilização das células. Os parâmetros adotados foram os mesmos da Tabela 3-3. Tal coluna de lixiviado pode ser considerada elevada para um aterro sanitário, porém é importante considerar que as células experimentais não possuíam drenagem interna para remoção de lixiviado e operaram por 26 meses.

As curvas obtidas das simulações estão apresentadas na Figura 3-4 e Figura 3-5. No eixo das ordenadas, os 100 primeiros centímetros correspondem à coluna de lixiviado e os 90 restantes, à camada de solo compactado. Adotaram-se valores iniciais de concentração do íon cloreto no lixiviado (1178 mg/L) e na água intersticial na camada de base $(5,4 \mathrm{mg} / \mathrm{L})$ para obtenção das curvas da Figura 3-4, e de íon amônio no lixiviado $(414 \mathrm{mg} / \mathrm{L})$ e na água intersticial da camada de base $(2,2 \mathrm{mg} / \mathrm{L})$ para obtenção das curvas da Figura 3-5. 

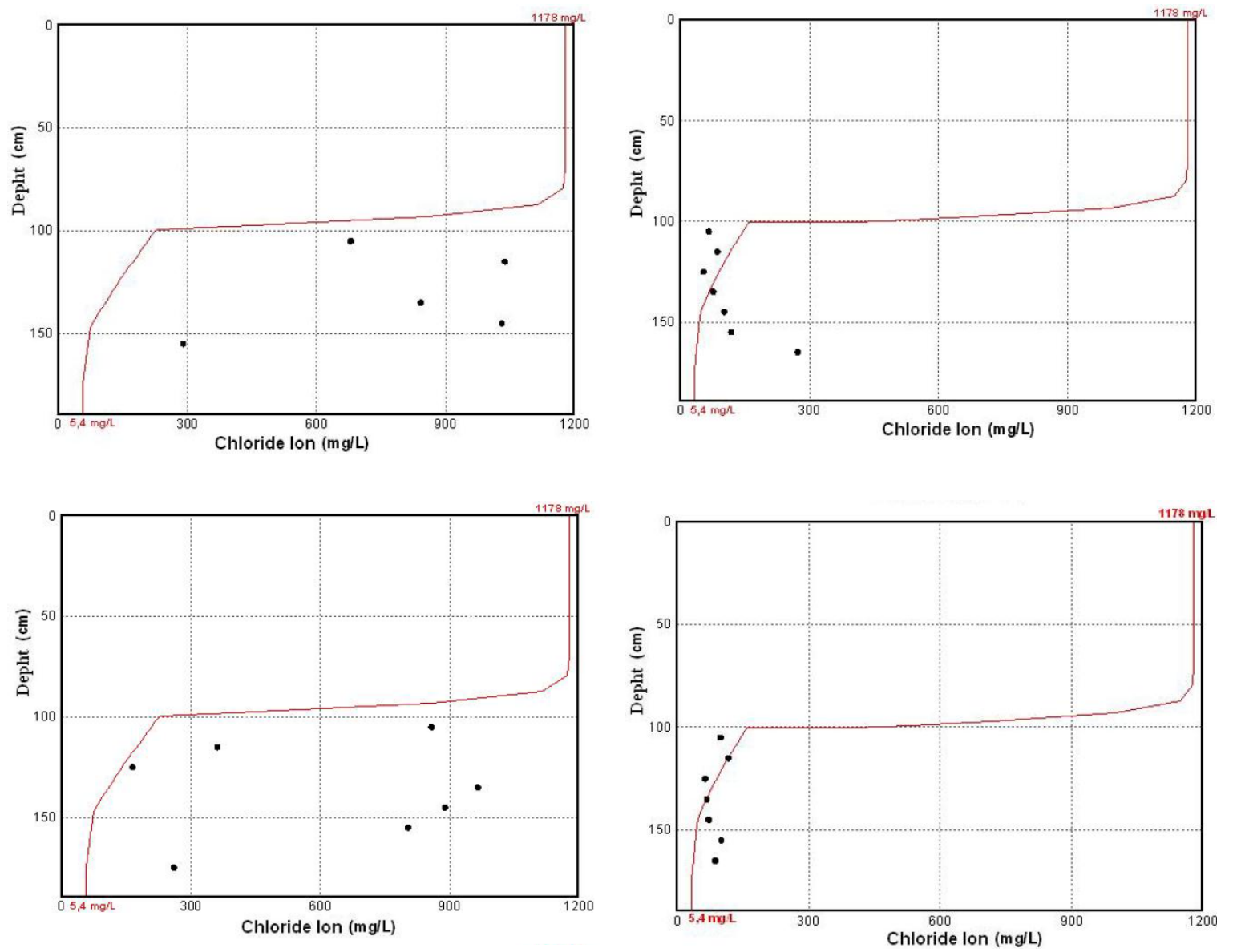

II
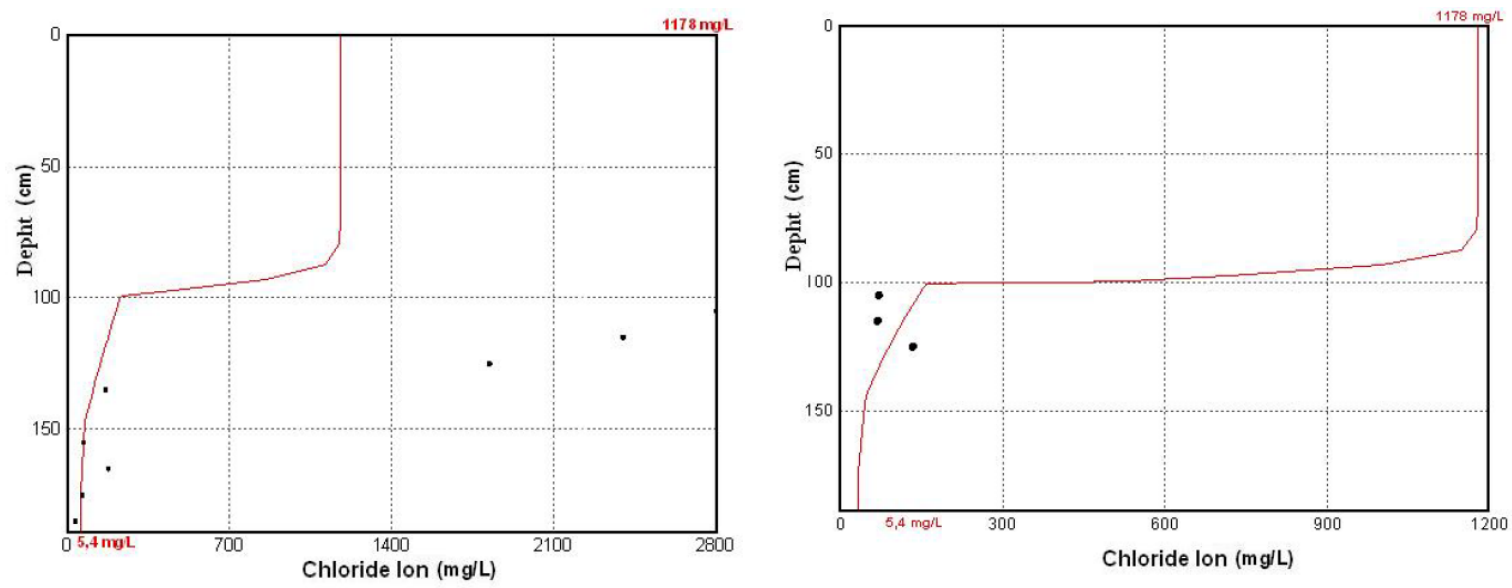

III

Célula 01

Célula 02

Figura 3-4 - Perfis da difusão do cloreto no solo sob o "liner", obtidos com os dados experimentais e por simulação numérica (RITTER et al., 2009). 

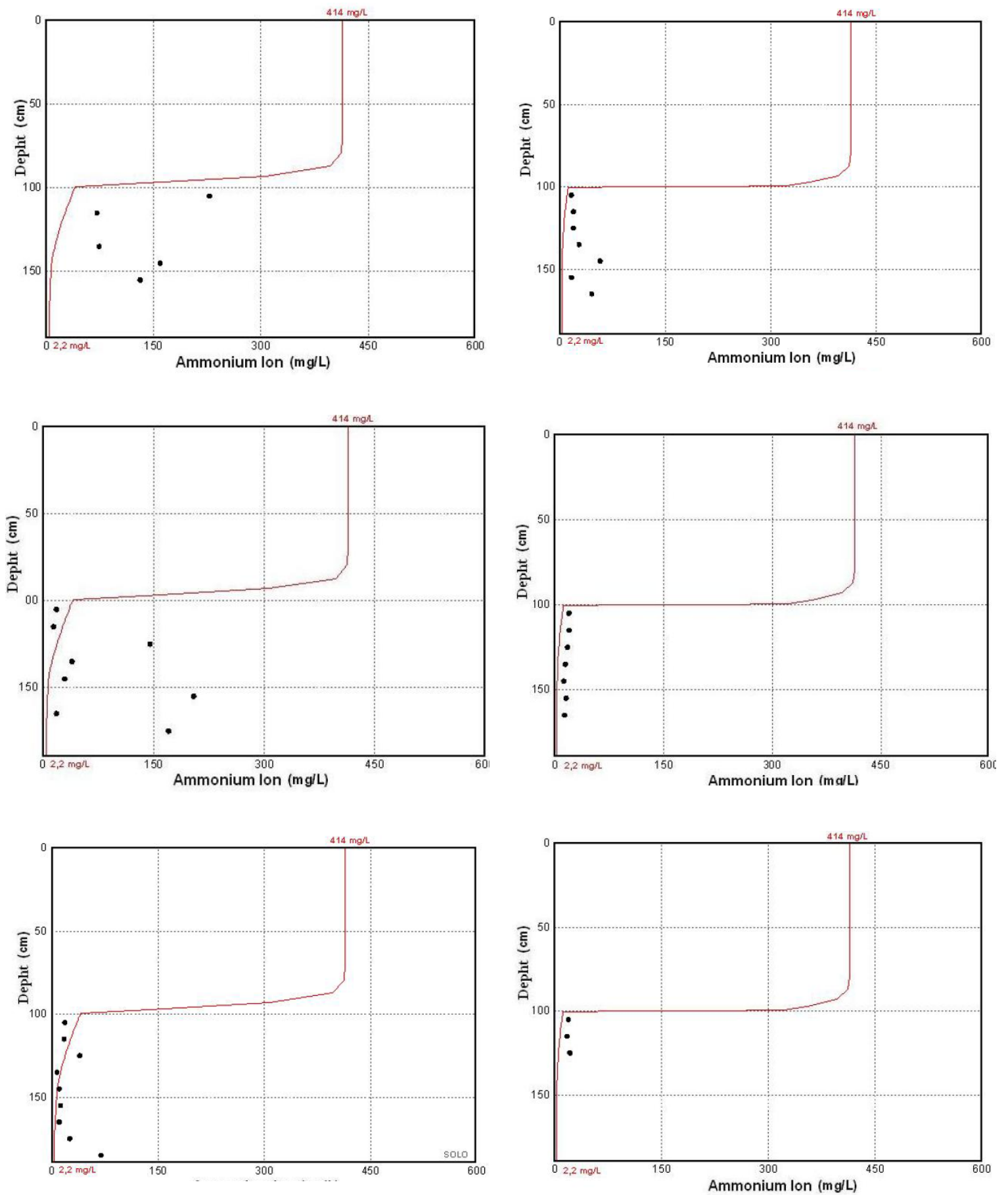

Célula 01

Célula 02

Figura 3-5 - Perfis da difusão do amônio no solo sob o "liner", obtidos com os dados experimentais e por simulação numérica (RITTER et al., 2009). 
Pode-se observar que as concentrações na camada de solo compactado da célula 1 são muito mais dispersas do que na da célula 2. É difícil a comparação em termos de valores médios, mas fica evidente que as concentrações são mais baixas na camada da célula 2. Na célula 1 , verifica-se que as curvas obtidas por simulação numérica não se ajustam bem às concentrações pontuais medidas, exceto para as amostras do perfil III. Já para a célula 2 as curvas se ajustaram bem às concentrações pontuais em todos os perfis.

Verifica-se que a utilização da geomembrana de PEAD reduziu a concentração dos íons presentes na água no solo em até 10 vezes quando se comparam os valores máximos medidos no perfil em cada caso. No entanto, as concentrações dos íons que atravessaram a geomembrana apresentaram valores superiores aos do background do solo, evidenciando que ocorre transporte de íons através da geomembrana de PEAD, possivelmente devido a defeitos, falhas de emendas ou danos na geomembrana, ou mesmo por difusão.

Ferrari et al. (2010) exumaram amostras de solo em diversas profundidades sob uma lagoa de acumulação de lixiviado de um aterro sanitário localizado no município de São Carlos/SP, o qual operava desde o ano de 1996 e foi encerrado em 2011. Em 2010 o aterro recebia, em média, 220 t/dia de RSU. A lagoa possuía as dimensões de $45 \times 25 \times 3,5$ metros, contava com revestimento de fundo formado apenas por solo compactado, sem geomembrana, e foi utilizada por mais de cinco anos para acumulação de lixiviado. O nível d'água local estava a uma profundidade superior a 14 metros. Segundo os autores, a lagoa funcionava, indiretamente, como um "permeâmetro em larga escala".

A região de São Carlos é caracterizada pela presença de arenitos e basaltos, originando, respectivamente, solos arenosos e argilosos. Especificamente o local do aterro sanitário é caracterizado por solos arenosos de depósitos coluviais e de arenitos; o solo compactado utilizado no revestimento de fundo da lagoa - uma areia argilosa - foi importado e sua composição era de $56 \%$ de areia, $8 \%$ de silte e $36 \%$ de argila (FERRARI et al., 2010).

A composição do lixiviado gerado no aterro sanitário de São Carlos, em diferentes anos, está apresentada na Tabela 3-5. 
Tabela 3-5 - Concentração dos constituintes presentes no lixiviado gerado no aterro sanitário de São Carlos em diferentes anos (FERRARI et al., 2010).

\begin{tabular}{|l|c|c|c|}
\hline Constituintes & $\mathbf{2 0 0 3}$ & $\mathbf{2 0 0 6}$ & $\mathbf{2 0 0 8}$ \\
\hline DBO $_{\mathbf{5}} \mathbf{( m g / L )}$ & 973 & 480 & - \\
\hline DQO (mg/L) & 3.440 & 1.420 & 6.396 \\
\hline COT (mg/L) & 372 & - & - \\
\hline Sólidos totais (mg/L) & - & - & 15.167 \\
\hline Nitrogênio amoniacal (mg/L) & 73 & 189 & 1.930 \\
\hline pH & 8,3 & 8,23 & 8 \\
\hline Arsênio (mg/L) & - & 0,027 & - \\
\hline Boro (mg/L) & - & 1,73 & - \\
\hline Cádmio (mg/L) & 0,040 & $<0,005$ & 0,00 \\
\hline Cloreto (mg/L) & 2,800 & - & 2,425 \\
\hline Cromo (mg/L) & 0,440 & 0,22 & 0,225 \\
\hline Ferro (mg/L) & 13,100 & 2,8 & 1,676 \\
\hline Chumbo (mg/L) & - & $<0,10$ & 0,069 \\
\hline Magnésio (mg/L) & - & 0,36 & 0,022 \\
\hline Níquel (mg/L) & - & $<0,01$ & 0,080 \\
\hline Potássio (mg/L) & - & - & 2,107 \\
\hline Sódio (mg/L) & - & - & 3,084 \\
\hline Sulfato (mg/L) & & - & - \\
\hline Zinco (mg/L) & - & - & 0,137 \\
\hline
\end{tabular}

O perfil do subsolo sob a lagoa esvaziada era formado pelas seguintes camadas: $7 \mathrm{~cm}$ de lodo, $30 \mathrm{~cm}$ de areia argilosa compactada e solo natural de fundação arenoso. Foram retiradas cinco amostras, sendo uma do lodo, uma do solo do revestimento de fundo e três do solo de fundação da lagoa - nomeadas amostras A, B, C, D e E -, cuja localização no perfil do subsolo está apresentada na Figura 3-6.

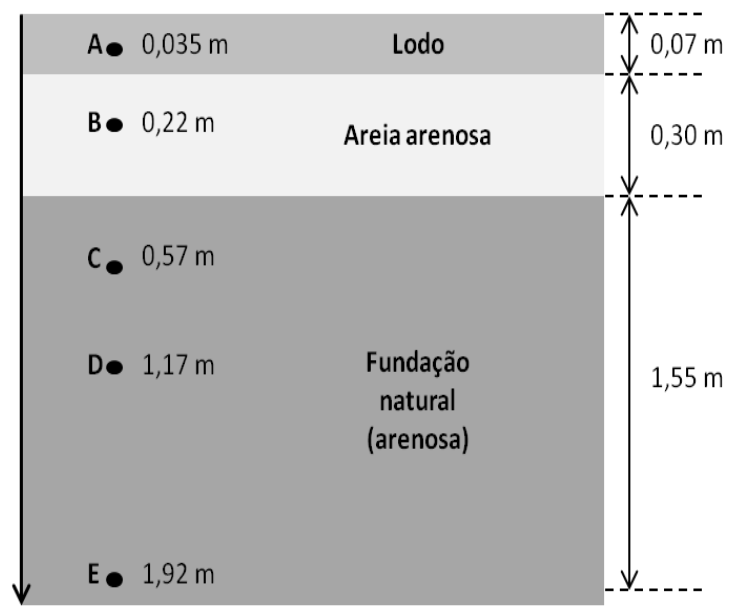

Figura 3-6 - Profundidades das amostras coletadas e perfil do subsolo sob a lagoa (FERRARI et al., 2010). 
A concentração dos constituintes presentes, em cada amostra adsorvidos no solo pode ser visualizada na Tabela 3-6. Não foram determinadas as concentrações dos constituintes na água intersticial do solo.

Tabela 3-6 - Concentração dos constituintes adsorvidos nas amostras de solo exumadas em $\mathrm{mg} / \mathrm{kg}$ (FERRARI et al., 2010).

\begin{tabular}{|l|c|c|c|c|c|}
\hline Constituintes & A & B & C & D & E \\
\hline Alumínio $\mathbf{( x ~ 1 0}^{\mathbf{3}}$ ) & 41,5 & 66,3 & 9,4 & 12,9 & 14,7 \\
\hline Antimônio & 6,2 & 20 & 1 & 1,1 & 2 \\
\hline Arsênio & $<0,4$ & $<0,5$ & $<0,3$ & $<0,4$ & $<0,3$ \\
\hline Boro & 100 & 217 & 25 & 29 & 33 \\
\hline Câdmio & $<0,4$ & $<0,5$ & $<0,3$ & $<0,4$ & $<0,3$ \\
\hline Cloreto & 1.788 & 322 & 123 & 174 & 188 \\
\hline Cromo & 32 & 8,6 & 4,6 & 4,7 & 5,2 \\
\hline Cobalto & 6,6 & 11 & 0,5 & $<0,4$ & 0,6 \\
\hline Cobre & 31 & 76 & 4,8 & 5,6 & 6,5 \\
\hline Ferro (x 10 $)$ & 31,7 & 72,3 & 8,2 & 10,2 & 11,1 \\
\hline Lítio & 14 & 4 & 2,9 & 3,4 & 3,7 \\
\hline Magnésio & 249 & 277 & 60 & 44 & 43 \\
\hline Mercúrio & 0,093 & 0,039 & $<0,02$ & $<0,03$ & $<0,02$ \\
\hline Níquel & 10 & 5,9 & 1,3 & 1,6 & 2 \\
\hline Sódio & 1,727 & 394 & 119 & 213 & 277 \\
\hline Vanádio & 106 & 269 & 24 & 28 & 33 \\
\hline Zinco & 59 & 20 & 2,2 & 2,8 & 6,1 \\
\hline Nitrogênio amoniacal & 64 & 75 & 29 & 56 & 37 \\
\hline NTK & 4.645 & 2.363 & 289 & 389 & 325 \\
\hline COT (x 104) & 6,1 & 23 & 0,92 & 1,3 & 1,2 \\
\hline
\end{tabular}

Para todas as variáveis analisadas, conforme pode ser visualizado na Tabela 3-6, as concentrações no solo local de fundação (amostras C, D e E) eram menores do que na camada impermeabilizante de solo compactado (amostra B), o que pode ser explicado pela capacidade atenuadora de poluentes do solo local ou por não ter sido atingido ainda o regime permanente no transporte de poluentes.

Os perfis das concentrações dos poluentes presentes no solo foram classificados em duas situações pelos autores: concentração no lodo (amostra A) superior à da camada de solo compactado (amostra B) e concentração na camada de solo compactado superior à do lodo. A primeira situação pode indicar que os compostos (cromo, lítio, mercúrio, níquel, cloreto, NTK e sódio) apresentam grande mobilidade na camada de areia argilosa compactada (amostra B), especialmente quando as concentrações na mesma e no subsolo (amostras C, D e E) eram da mesma ordem de grandeza. Na segunda situação, os autores inferiram que os elementos possuem 
baixa mobilidade na camada de areia argilosa compactada (alumínio, antimônio, boro, COT, cobalto, cobre, ferro, vanádio e zinco), demonstrando a capacidade de adsorção do solo, especialmente nos casos em que a concentração no subsolo é significativamente inferior à concentração na areia argilosa compactada.

Outra possível interpretação baseia-se na hipótese de que há diferença entre a migração do lodo para o solo compactado e a migração do solo compactado para o subsolo. Algumas variáveis seriam mais móveis no lodo e migrariam mais rapidamente do lodo para o solo compactado. A camada de solo compactado, por outro lado, retém todas as variáveis, embora com eficiência diferenciada, uma vez que as concentrações no solo local apresentaram-se sempre menores do que no lodo ou no solo compactado.

É importante observar que a camada de solo compactado do revestimento de fundo da lagoa possuía uma pequena espessura $(30 \mathrm{~cm})$, menor que a empregada atualmente $(60 \mathrm{~cm}$, no mínimo). Além disso, possivelmente a condutividade hidráulica era superior a $1 \times 10^{-9} \mathrm{~m} / \mathrm{s}$ (valor máximo indicado para revestimento de fundo de aterros sanitários), pois tratava-se de uma areia argilosa.

Estudos do subsolo sob um local de disposição de resíduos sólidos urbanos em Sarnia, Canadá, são apresentados em Rowe et al. (1995). O local consistia de aproximadamente $7,5 \mathrm{~m}$ de lixo (incluindo cobertura) dispostos em uma trincheira de 5,5 $\mathrm{m}$ de profundidade, escavada através de uma camada ressecada de argila marrom oxidada quando o local foi utilizado como jazida de solo. Essa camada era altamente fissurada nos 4 primeiros metros e muito menos fissurada entre os $4 \mathrm{e}$ $6,5 \mathrm{~m}$ de profundidade. Quando a investigação foi realizada, a camada havia sido exposta por 15 anos ao lixiviado gerado na massa de resíduos. Ensaios de permeabilidade realizados com amostras indeformadas mostraram que a condutividade hidráulica da camada superior do subsolo praticamente não mudou com a infiltração do lixiviado, apresentando até um ligeiro decréscimo. As hipóteses sugeridas foram a precipitação de metais pesados e a colmatação bacteriana.

Foram obtidos alguns perfis de concentração de solutos no subsolo. As concentrações de cloreto e sódio na água intersticial estão apresentadas na Figura 3-7, resultando em um coeficiente de difusão estimado para o cloreto de 6,3 $\mathrm{x}$ $10^{-10} \mathrm{~m}^{2} / \mathrm{s}$. Na Figura 3-8 são apresentados os perfis de concentração total dos 
elementos chumbo, cobre, ferro, manganês e zinco na água intersticial do solo. Pode-se observar que tais metais migraram até no máximo $20 \mathrm{~cm}$.

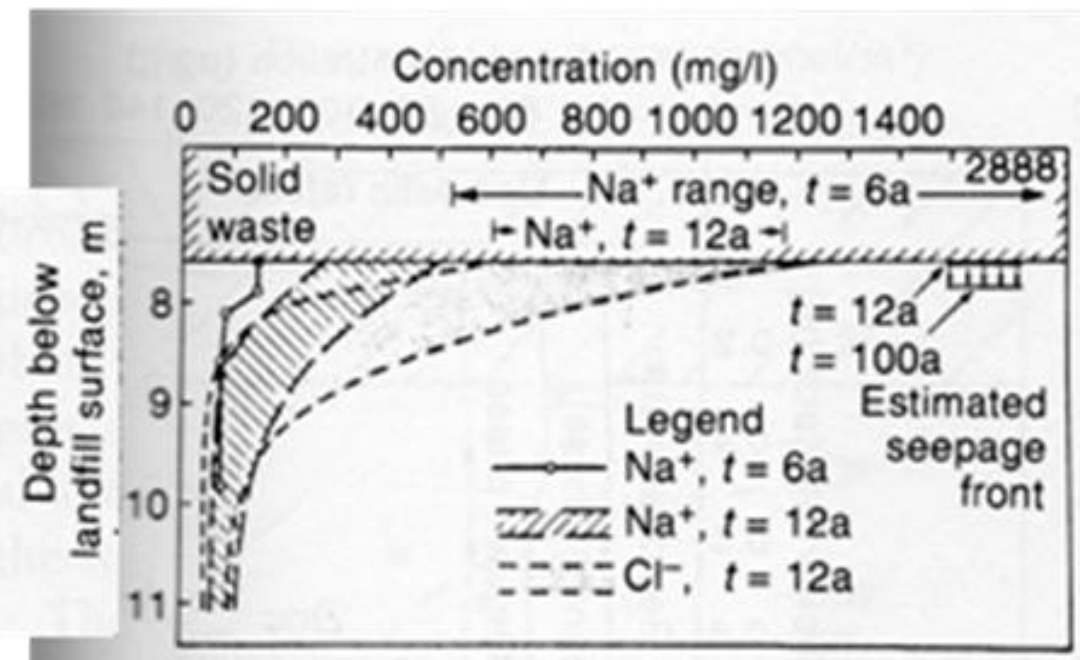

Figura 3-7 - Concentração dos íons sódio e cloreto na água intersticial do subsolo do local de disposição de resíduos de Sárnia após 12 anos de difusão (ROWE et al.,1995).

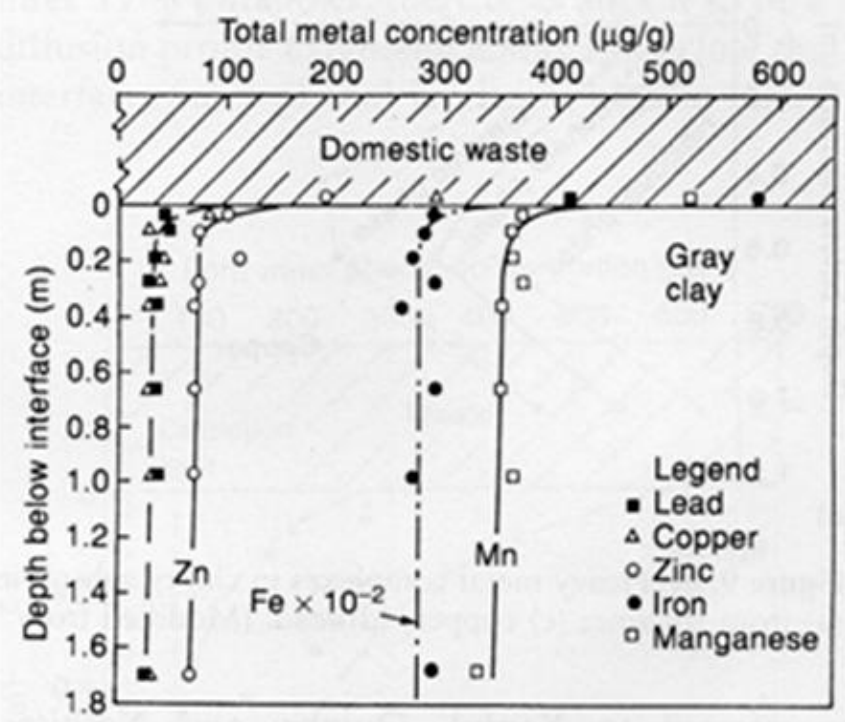

Figura 3-8 - Concentração total de metais no subsolo do local de disposição de resíduos de Sárnia após 16 anos de difusão (ROWE et al.,1995). 


\subsection{Compatibilidade entre solo e lixiviado de aterro sanitário}

A percolação de soluções através dos solos pode implicar em alterações nos índices físicos e nos parâmetros de comportamento geotécnico, como a plasticidade, permeabilidade, compressibilidade ou resistência. O solo é considerado compatível com a solução percolante quando há constância das características e propriedades geotécnicas após o contato com a solução.

A compatibilidade geralmente é verificada por meio de ensaios de caracterização ou de propriedades geotécnicas realizados antes e após o contato do solo com a solução poluente de estudo. Enquanto alguns autores preferem se pautar por ensaios índices, outros realizam ensaios de resistência, permeabilidade, adensamento e expansão, ou seja, determinam diretamente a constância ou variação dos parâmetros relativos às propriedades geotécnicas de interesse.

Shackelford (1994) mencionou os ensaios de limites de Atterberg, permeabilidade e sedimentação em água e em solução poluente como os ensaios tipicamente realizados para estudar os efeitos das interações entre solo e resíduos na condutividade hidráulica do solo. Gurjão (2005) acrescentou o estudo das curvas de distribuição granulométrica obtidas por sedimentação e por granulômetro a laser, com e sem defloculante no primeiro caso, e com e sem ultra-som no segundo caso.

Alguns trabalhos investigaram compatibilidade de solos com lixiviado de aterros sanitários, como os de Hamada et al. (2004), Iwai (2005), Francisca \& Glatstein (2010), França et al. (2007) e e Frempong \& Yanful (2008) citados por Soares (2012).

Soares (2012) realizou ensaios de permeabilidade, cisalhamento direto, adensamento e expansão para verificar a compatibilidade de um solo saprolítico de filito, um solo silto-arenoso de grande ocorrência na Região Metropolitana de São Paulo, ao lixiviado de aterro sanitário. Os ensaios de compatibilidade foram realizados com corpos-de-prova compactados no ponto ótimo da energia modificada. O ensaio de permeabilidade foi iniciado com percolação de água e posteriormente substituiu-se o líquido percolante por lixiviado coletado em aterro sanitário. Houve uma queda de duas ordens de grandeza (100 vezes) na condutividade hidráulica ao lixiviado em relação à água, conforme pode ser observado na Figura 3-9. 


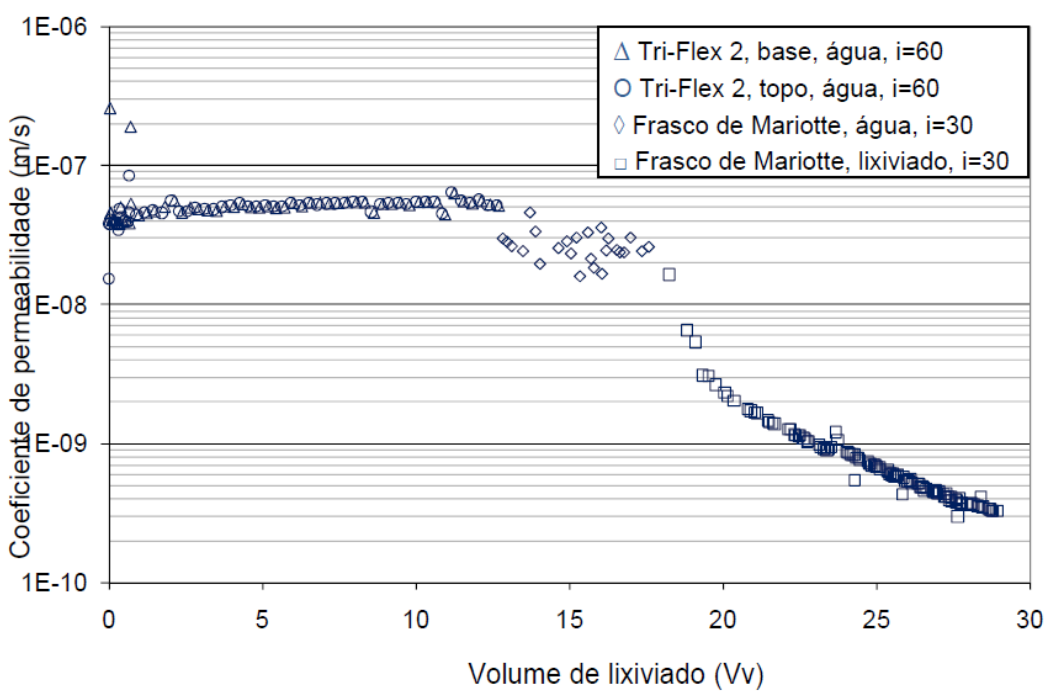

Figura 3-9 - Ensaio de permeabilidade em solo saprolítico com água e lixiviado (SOARES, 2012).

Ensaios de adensamento determinaram um índice de compressão de 0,122 e índice de expansão 0,058; na presença de lixiviado, os índices de compressão e de expansão foram, respectivamente, $19 \%$ e $28 \%$ superiores do que com água (Figura 3-10). Ensaios de cisalhamento direto mostraram que o solo natural apresenta coesão de $10 \mathrm{KPa}$ e ângulo de atrito de $32^{\circ}$. Quando o líquido de inundação foi o lixiviado, houve aumento de $53 \%$ na coesão e decréscimo de $15 \%$ no ângulo de atrito do solo. No entanto, as envoltórias de resistência resultaram muito próximas para a faixa estudada de tensões confinantes, conforme se observa na Figura 3-11, onde também estão apresentados resultados de ensaios de cisalhamento realizados com mistura do solo com $5 \%$ de bentonita.

O solo natural foi identificado como expansivo, com $15 \%$ de expansão livre em média, apresentando pressão de expansão de $20 \mathrm{kN} / \mathrm{m}^{2}$ quando na presença de água. Com o lixiviado, a expansão livre diminuiu para $9 \%$ e a pressão de expansão aumentou para $23 \mathrm{kN} / \mathrm{m}^{2}$.

Pelos resultados apresentados, pode-se concluir que as propriedades geotécnicas do solo compactado não foram alteradas significativamente pelo contato com o lixiviado a ponto de comprometer seu desempenho como camada impermeabilizante de revestimento de fundo de aterro sanitário. 


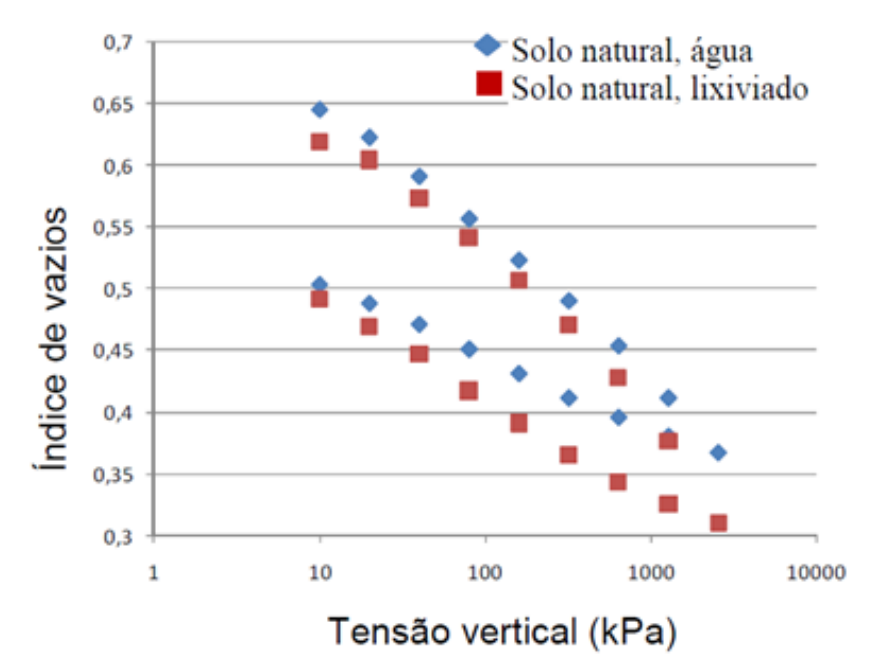

Figura 3-10 - Ensaios de adensamento com água e lixiviado (SOARES, 2012).

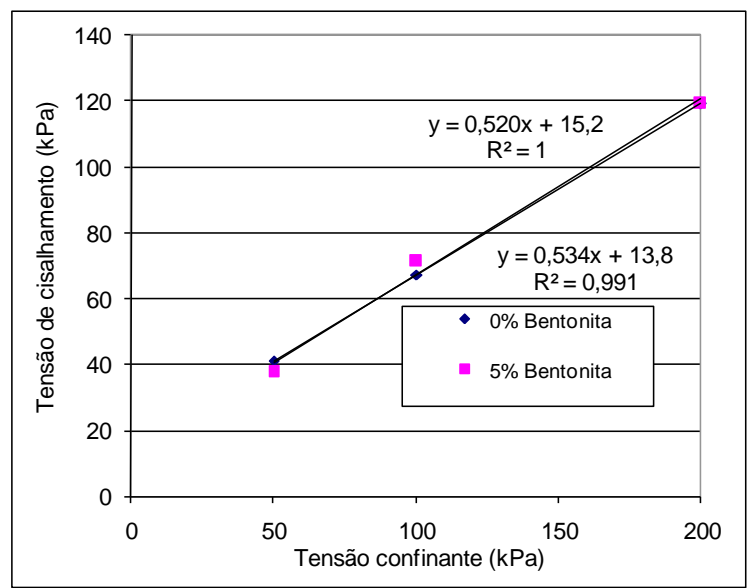

(a)

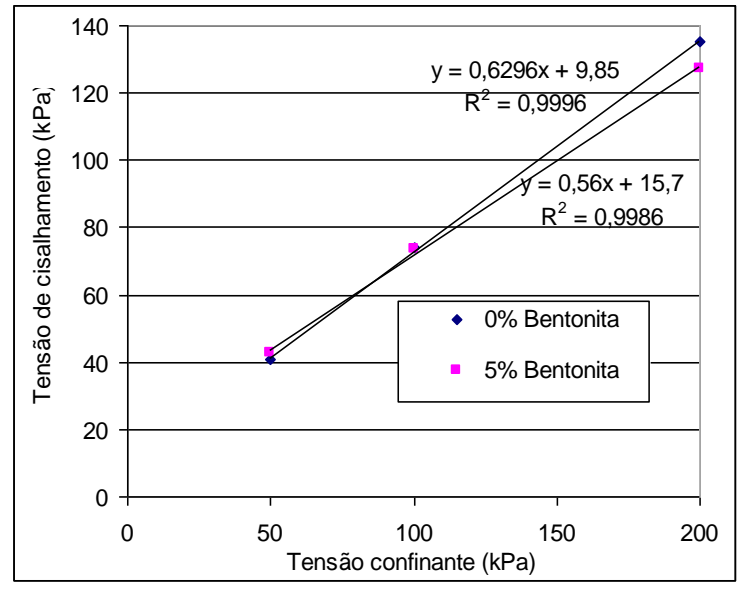

(b)

Figura 3-11 - Envoltórias de resistência do ensaios de cisalhamento na presença de: (a) água; (b) lixiviado (SOARES, 2012).

CORRÊA (2001) estudou a compatibilidade de três solos de Brasília/DF a lixiviado de aterro controlado por meio de ensaios de coluna com corpos-de-prova compactados. Os ensaios de coluna mostraram que houve em efeito dispersante do lixiviado nos agregados do solo: as curvas granulométricas mostraram um aumento das frações finas e redução, por consequência, das frações grosseiras.

O valor do índice de plasticidade permaneceu relativamente inalterado, exceto para uma amostra. ACTC das amostras aumentou após sofrerem infiltração com lixiviado. Nos ensaios de expansão livre, a expansão dos solos em água foram superiores aos valores apresentados pelas amostras após percolação por lixiviado. 
A permeabilidade diminuiu com a percolação do lixiviado, conforme mostrado na Tabela 3-7.

Tabela 3-7 - Condutividade hidráulica à água e ao lixiviado (CORRÊA, 2001).

\begin{tabular}{|c|c|c|c|}
\hline \multirow{2}{*}{ Solo } & \multicolumn{3}{|c|}{ Amostra } \\
\cline { 2 - 4 } & SOB2 & SAM2 & SAM3 \\
\hline $\begin{array}{c}\mathrm{K}_{\mathrm{w}}, \begin{array}{c}\text { condutividade hidráulica } \\
\text { à água (cm/s) }\end{array} \\
1 \times 10^{-5}\end{array}$ & $3 \times 10^{-6}$ & $5 \times 10^{-5}$ \\
\hline $\begin{array}{c}\mathrm{K}_{\mathrm{ch}}, \text { condutividade hidráulica } \\
\text { ao lixiviado (cm/s) }\end{array}$ & $2 \times 10^{-7}$ & $2 \times 10^{-7}$ & $3 \times 10^{-7}$ \\
\hline $\mathrm{K}_{\mathrm{w}} / \mathrm{K}_{\mathrm{ch}}$ & 50 & 15 & 166 \\
\hline
\end{tabular}




\section{MATERIAIS E MÉTODOS}

\subsection{Plano geral de pesquisa}

A investigação deste trabalho compreendeu estudos de contaminação in situ e em laboratório, permitindo a comparação dos resultados e métodos utilizados.

O aterro sanitário de Botucatu, que operou como aterro controlado por mais de 10 anos e recentemente passou por obras para torná-lo um aterro sanitário, foi escolhido como estudo de caso. O lixiviado do aterro era coletado e armazenado em uma lagoa sem revestimento de fundo. Esta lagoa, por ocasião das obras de recuperação, foi desmobilizada e esvaziada para a construção de uma nova lagoa com impermeabilização de fundo. O lixiviado foi retirado por caminhões-fossa e encaminhado para estação de tratamento de esgoto de Botucatu, operada pela SABESP.

Decidiu-se, então, coletar amostras de solo sob a lagoa desmobilizada, para analisar o transporte in situ de certos poluentes presentes no lixiviado. A contaminação foi avaliada através de análise de dados de campo, com a coleta de amostras de solo contaminado e de lixiviado e posterior análise química de constituintes adsorvidos no solo contaminado e presentes no lixiviado.

Por outro lado, amostras indeformadas do solo local não contaminado foram também coletadas para a realização de ensaios de caracterização geotécnica e ensaios laboratoriais de transporte de poluentes com lixiviado gerado no aterro.

O fluxograma das atividades realizadas na pesquisa está apresentado na Figura 4-1. 


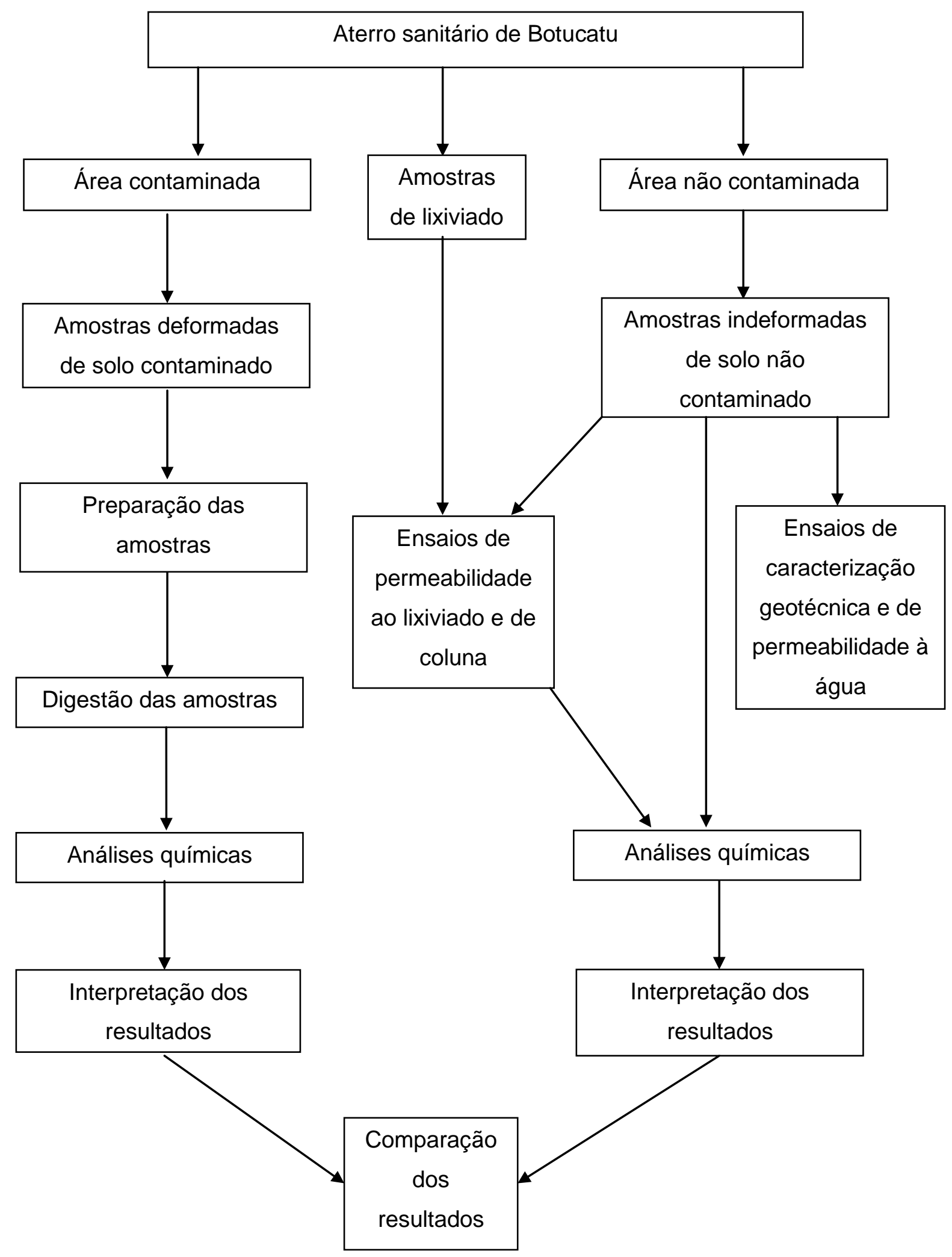

Figura 4-1 - Fluxograma da investigação experimental de campo e de laboratório. 


\subsection{Caracterização da região do aterro sanitário de Botucatu}

O aterro sanitário de Botucatu está localizado no município de mesmo nome, no interior do estado de São Paulo.

O aterro opera desde o ano de 1996, ou seja, há 17 anos. Atualmente são dispostos $90 \mathrm{t} / \mathrm{dia}$ de RSU, aproximadamente.

A lagoa de acumulação de lixiviado, desmobilizada em 2011, operou durante 15 anos e tinha profundidade de 2,5 metros.

Uma série histórica com dados meteorológicos referentes ao município de Botucatu estão apresentados na Tabela 4-1.

Tabela 4-1- Série histórica de dados meteorológicos do município de Botucatu (UNICAMP, 2012).

\begin{tabular}{|c|c|c|c|}
\hline Meses & $\begin{array}{c}\text { Temperatura } \\
\left({ }^{\circ} \mathbf{C}\right)\end{array}$ & $\begin{array}{c}\text { Precipitação } \\
(\mathbf{m m})\end{array}$ & $\begin{array}{c}\text { Evapotranspiração } \\
\text { Potencial (mm) }\end{array}$ \\
\hline Janeiro & 23 & 223 & 111 \\
\hline Fevereiro & 23 & 228 & 102 \\
\hline Março & 23 & 148 & 103 \\
\hline Abril & 20 & 62 & 75 \\
\hline Maio & 18 & 48 & 56 \\
\hline Junho & 17 & 46 & 44 \\
\hline Julho & 17 & 30 & 44 \\
\hline Agosto & 18 & 32 & 56 \\
\hline Setembro & 20 & 56 & 68 \\
\hline Outubro & 21 & 129 & 84 \\
\hline Novembro & 22 & 113 & 93 \\
\hline Dezembro & 22 & 187 & 105 \\
\hline
\end{tabular}

\subsubsection{Caracterização geológico-geotécnica}

O município de Botucatu apresenta uma estratigrafia associada aos arenitos das Formações Botucatu e Pirambóia (ambas fazendo parte do Grupo Geológico São Bento), em sobreposição a rochas ígneas efusivas basálticas, com diversos afloramentos da Formação Serra Geral, além de sedimentos relacionados às redes de drenagem existentes (FÚLFARO \& BJOMBERG, 1993).

A Formação Botucatu é constituída por arenitos de granulação média a fina com coloração vermelha, rósea ou amarelo-clara. A Formação Pirambóia é constituída de arenitos de granulação média a fina e coloração branco-alaranjada e avermelhada. 
A Formação Serra Geral compreende um conjunto de rochas basálticas originárias de derrames vulcânicos, de coloração cinza a negra, que se encontram intercalados por depósitos areníticos de granulação fina de origem eólica (com características da Formação Botucatu) (FÚLFARO \& BJOMBERG, 1993).

\subsubsection{Pedologia}

Segundo IBGE (2012), a formação pedológica do subsolo local é a latossolo vermelho +LV42 - LV Distrófico + PV Distrófico + LV Eutroférrico (Figura 4-2).

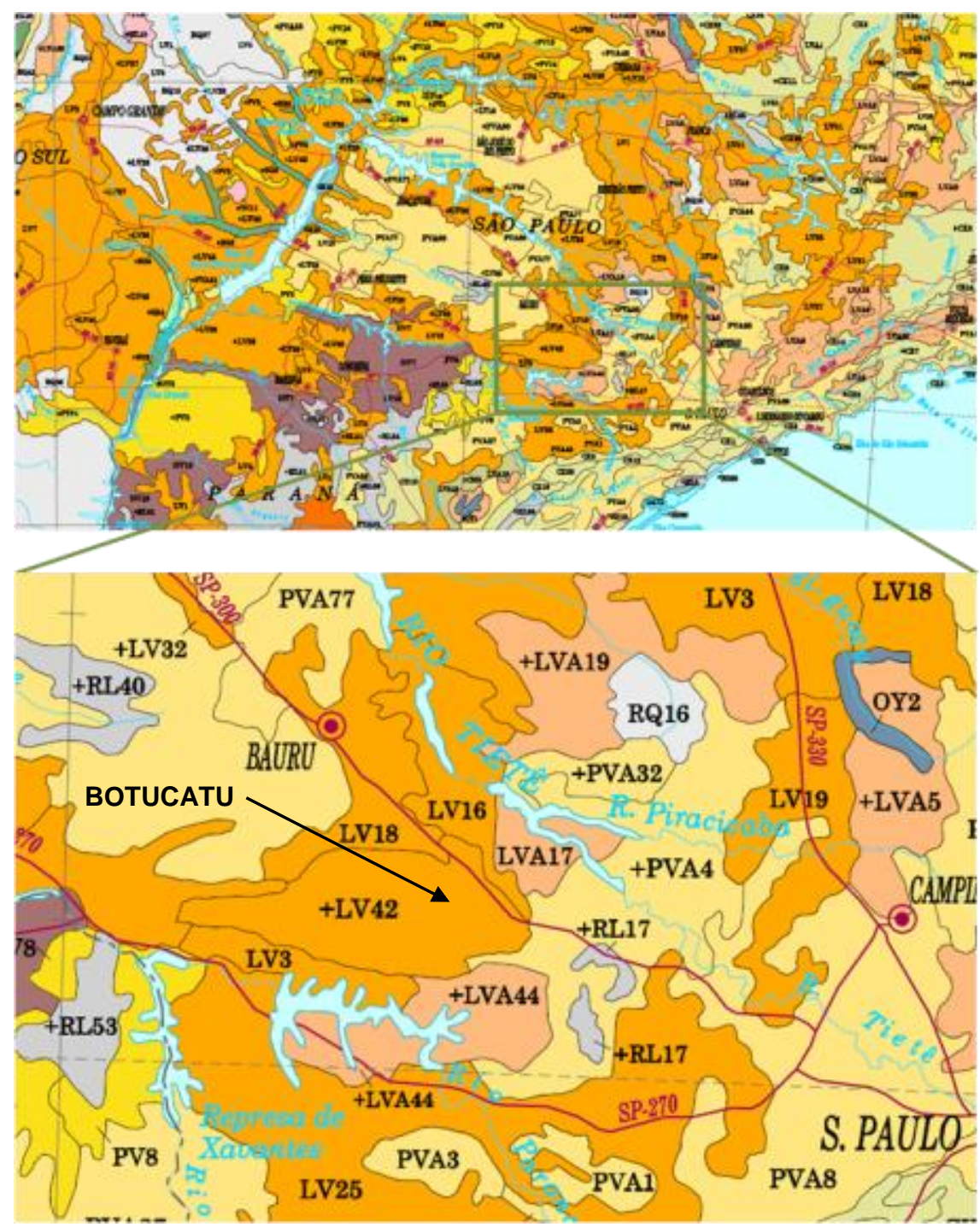

Figura 4-2 - Mapeamento pedológico do subsolo da região de Botucatu (modificado de IBGE, 2012). 
A classe dos latossolos constitui o agrupamento de solos mais extenso do estado de São Paulo, correspondendo a cerca de $52 \%$ de sua área. Mesmo os latossolos bastante argilosos apresentam elevada porosidade - com valores típicos na faixa de $50 \%$ a $60 \%$ - e boa drenagem interna (OLIVEIRA, 1999).

As formações Botucatu e Pirambóia são constituídas de pacotes homogêneos com grandes espessuras, onde a contribuição de material fino é menor que $20 \%$. Em algumas localidades a fração argila pode atingir valores de capacidade de troca catiônica (CTC) da ordem de $15 \mathrm{cmol}_{\mathrm{c}} / \mathrm{kg}$ de massa seca (RODRIGUES et al.,1993). Os solos laterizados provenientes dessas formações são tipicamente arenosos.

Atualmente, procuram-se locais com baixa permeabilidade natural e lençol freático profundo, para evitar a dispersão de poluentes nas águas subterrâneas. Os solos lateríticos, mesmo com elevada porosidade no estado natural, podem apresentar coeficientes de condutividade hidráulica baixos quando adequadamente compactados, mesmo nas variedades mais arenosas.

\subsection{Materiais}

\subsubsection{Solo estudado}

O solo estudado é uma areia argilosa laterítica, localizado no aterro sanitário de Botucatu. A localização do aterro está apresentada na Figura 4-3.

\subsubsection{Amostragem do solo natural}

O solo natural foi amostrado no interior do terreno do aterro de Botucatu em 31 de agosto de 2011, em local afastado e a montante dos maciços de resíduos (o fluxo das águas subterrâneas e o local de amostragem podem ser visualizados na Figura 4-4), com coordenadas geográficas UTM 756.247 m E e 7.459 .857 m S e cota 847 metros. 

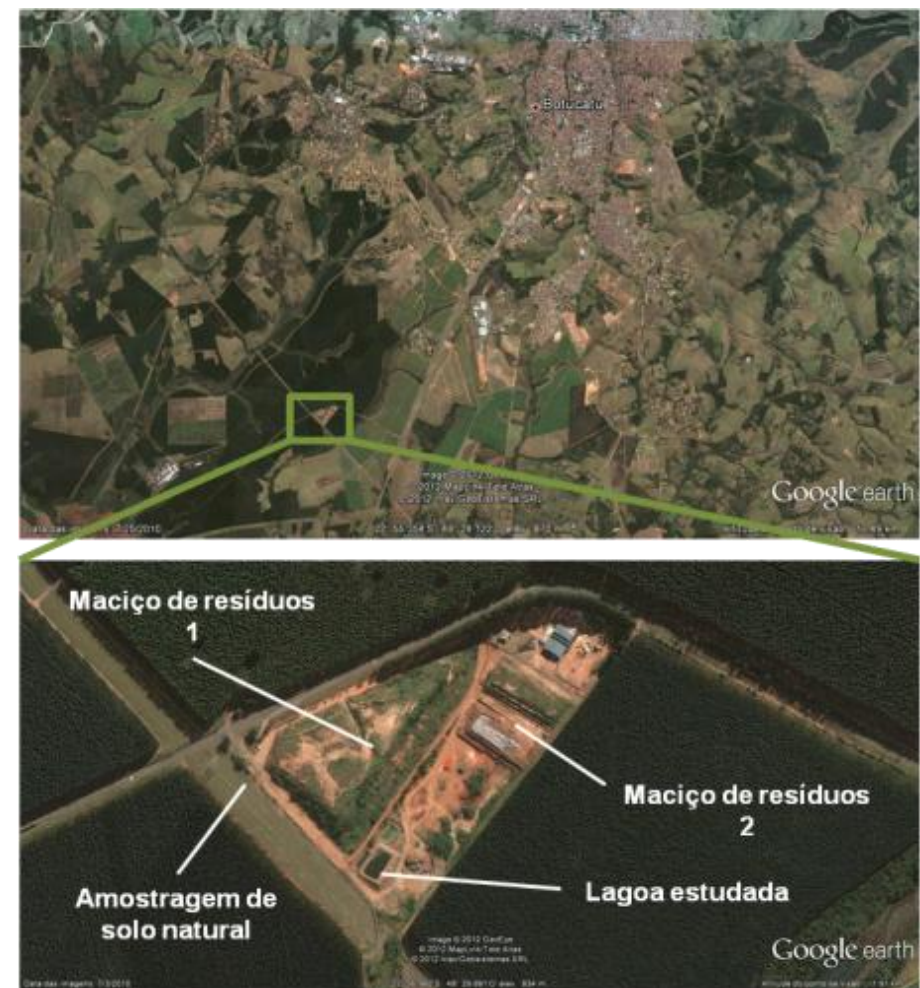

Figura 4-3 - Vista regional e superior do empreendimento (fonte: modificado de Google Earth em 06.02.2011).

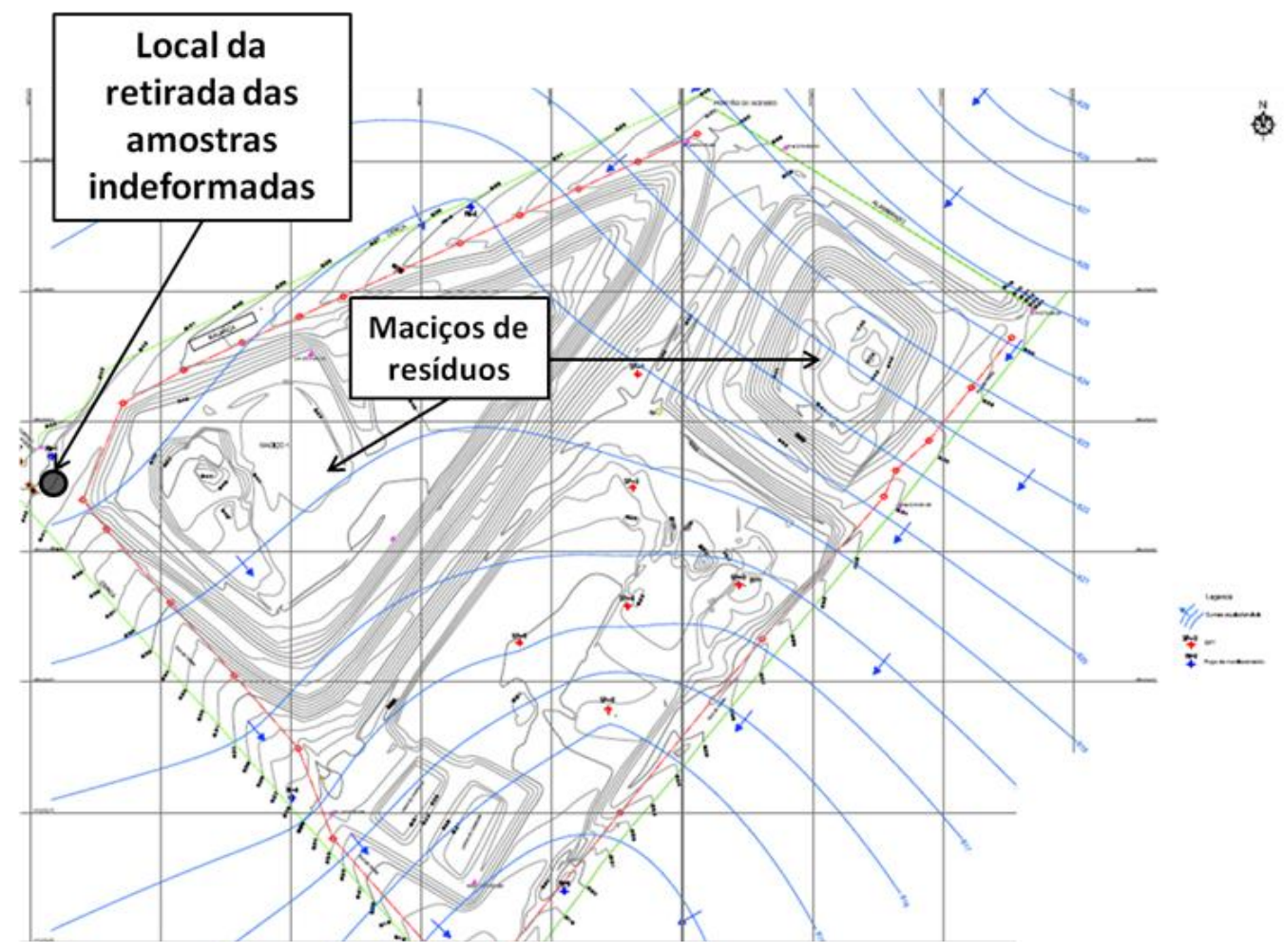

Figura 4-4 - Mapa potenciométrico da região. As setas de cor azul indicam a direção e o sentido do movimento das águas subterrâneas. 
Foram coletados 2 blocos indeformados de solo (Figura 4-5), os quais foram selados com papel alumínio e com faixa-tecido e, em seguida, parafinados. Os blocos foram armazenados no Laboratório de Mecânica dos Solos (LMS) da Escola Politécnica da USP na mesma data da coleta, em câmera úmida. O topo dos blocos indeformados $\mathrm{n}^{\circ} 1$ e $\mathrm{n}^{\circ} 2$ estavam a profundidades de, respectivamente, 1,03 e 0,94 metros.

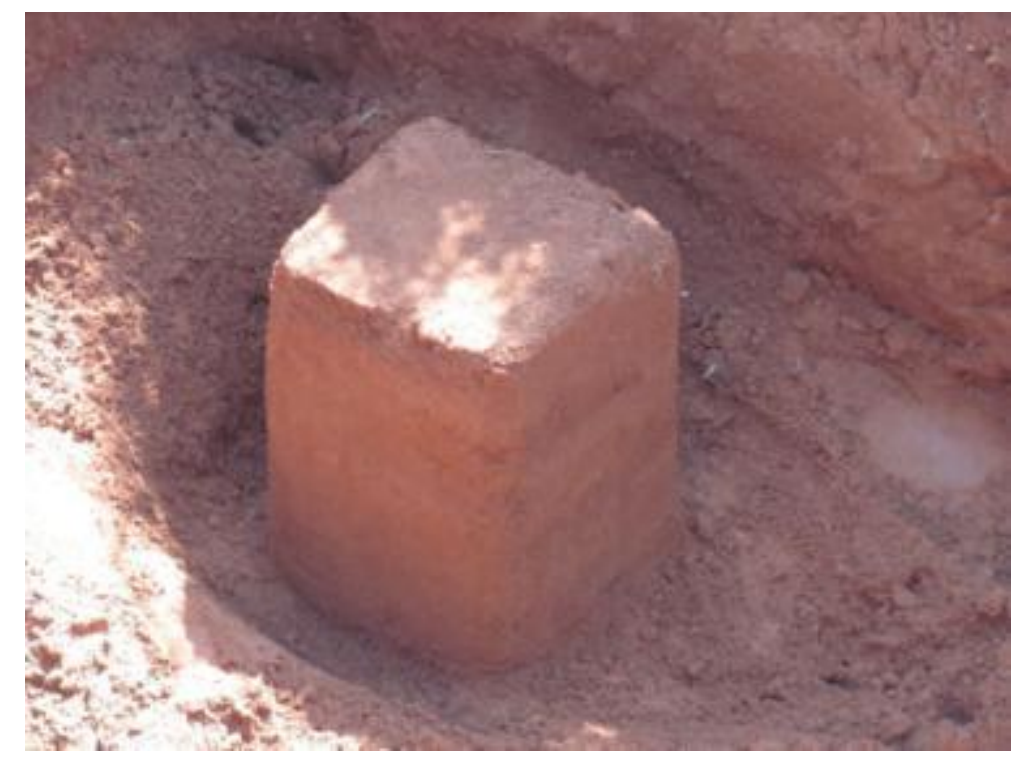

Figura 4-5 - Bloco indeformado retirado para ensaios de laboratório.

O solo deformado derivado da talhagem dos blocos indeformados também foi amostrado para utilização em ensaios que não necessitam de amostras indeformadas.

\subsubsection{Amostragem de solo contaminado}

Na Figura 4-6 pode ser visualizada a lagoa com acúmulo de lixiviado quando estava em operação.

As amostras de solo contaminado utilizadas nesta pesquisa foram retiradas em 16 de janeiro de 2013, após o esvaziamento e desmobilização da lagoa.

Para a amostragem do solo contaminado, foram locados 3 pontos para retirada de amostras, sendo que em cada ponto seriam retiradas amostras em diversas profundidades (perfis): superficiais (lodo) e nas profundidades $0,25 \mathrm{~m}, 0,50 \mathrm{~m}, 1,00$ 
$\mathrm{m}, 2,00 \mathrm{~m}$ e 4,00 m. A locação dos perfis planejados para retiradas das amostras está apresentada na Figura 4-7 (círculos na cor vermelha).

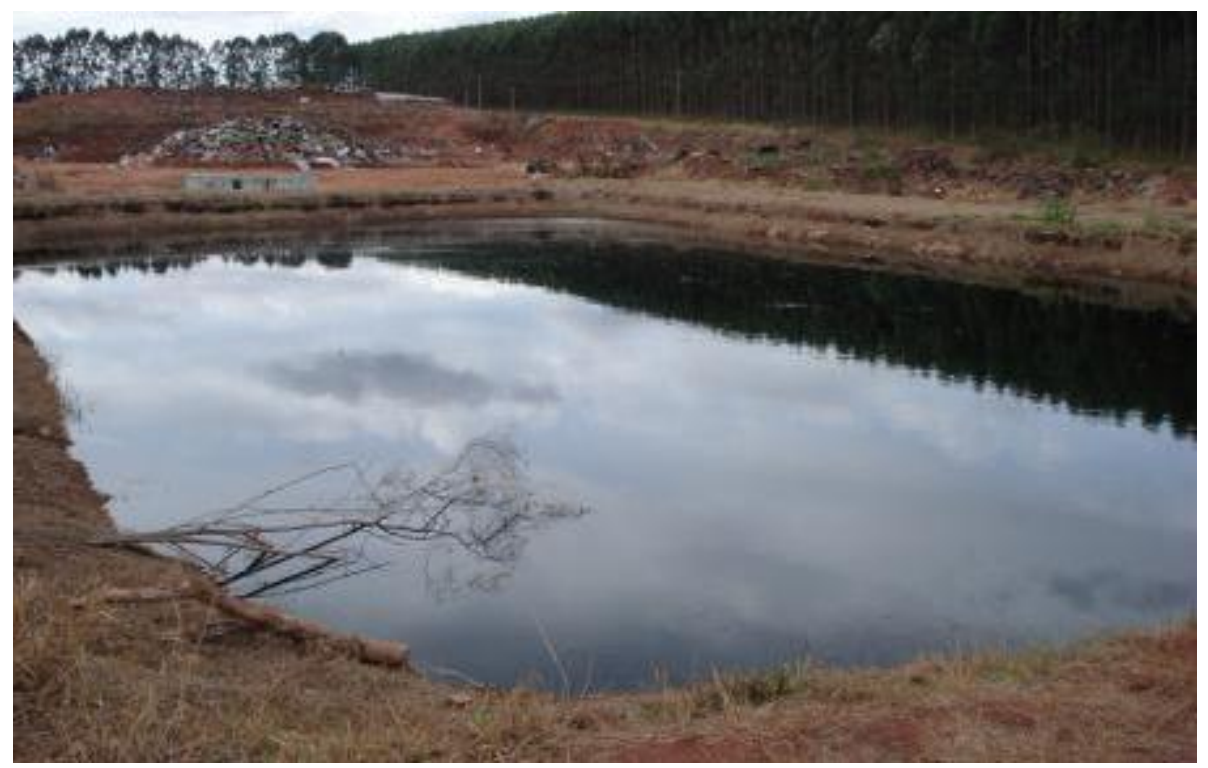

Figura 4-6 - Lagoa de acumulação de lixiviado sem impermeabilização.

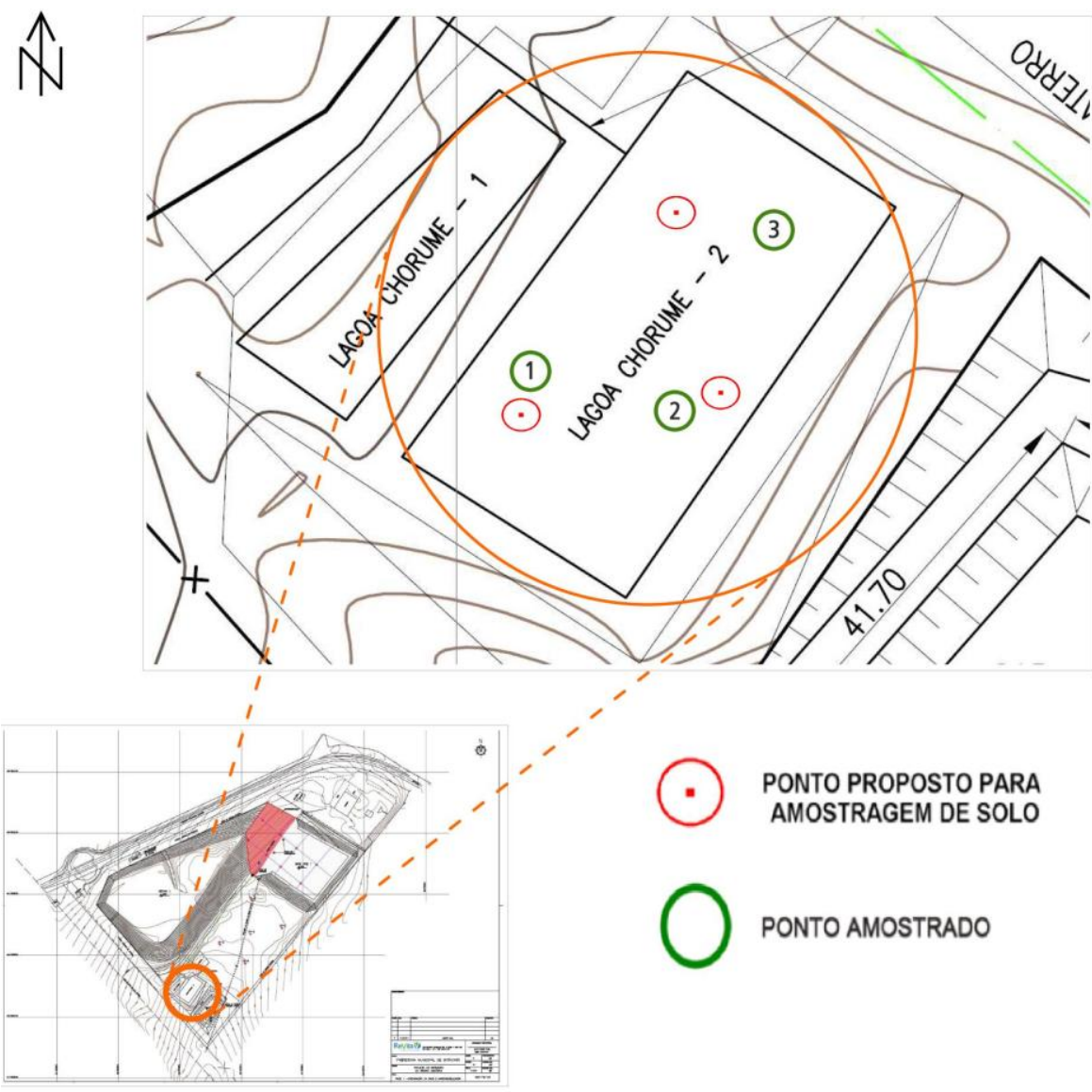

Figura 4-7 - Locação dos perfis planejados para serem amostrados e locação dos perfis executados. 
A locação dos perfis amostrados foi diferente do planejado, devido à baixa capacidade de suporte, principalmente do fundo da lagoa e dos taludes, dificultando a garantia de segurança da equipe de sondagem, tanto em termos de acessibilidade à lagoa, quanto de realização dos trabalhos de amostragem. A locação final pode ser visualizada na Figura 4-7 (círculos na cor verde).

A amostragem foi realizada com trado manual do tipo caneco, sendo que antes da retirada de cada amostra a extremidade do trado era lavada manualmente com água Milli-Q, evitando, assim, a contaminação cruzada.

Durante a amostragem, verificou-se que até pelo menos 0,5 metro de profundidade os vazios do solo estavam preenchidos com lodo.

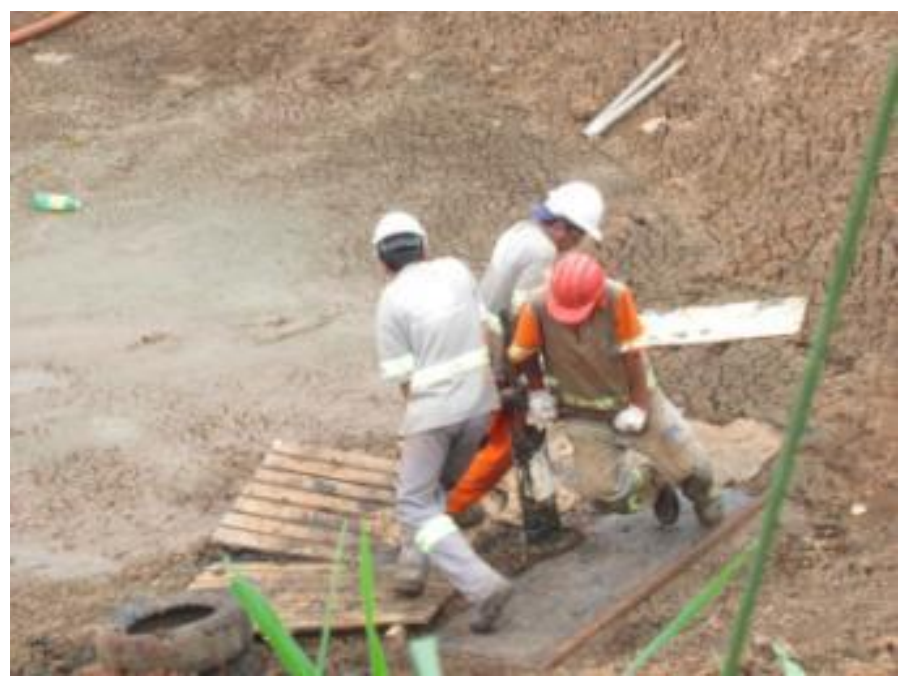

Figura 4-8 - Execução da amostragem de solo contaminado.

\subsubsection{Lixiviado real}

Nos ensaios laboratoriais de transporte de poluentes, utilizou-se o lixiviado gerado no aterro sanitário de Botucatu. O líquido foi obtido no aterro em três coletas distintas, armazenado em recipiente plástico, levado ao LMS e conservado em geladeira, preservando as características dos constituintes presentes. A primeira amostra foi coletada em dezembro de 2011 no maciço em operação; a segunda e a terceira coletas, respectivamente em janeiro e março de 2013, foram realizadas na nova lagoa de acumulação (impermeabilizada). 
Como em Soares (2012), antes da utilização de amostras do lixiviado nos ensaios laboratoriais, o mesmo foi passado em papel-filtro, retirando assim, do meio aquoso, sólidos em suspensão que poderiam colmatar os corpos-de-prova de solo.

O lixiviado foi analisado quimicamente segundo os parâmetros selecionados para a investigação de laboratório e de campo: arsênio, cádmio, carbono orgânico total (COT), chumbo, cloreto, cobre, cromo, ferro, manganês, níquel, nitrogênio Kjeldahl total (NKT) e zinco.

Os métodos de determinação de cloreto, COT e NKT foram os presentes em Eaton \& Franson (2005). Os métodos utilizados para as análises químicas das amostras efluentes do ensaio de coluna, amostras de solo natural, lodo e solo contaminado também estão presentes em Eaton \& Franson (2005).

\subsection{Análises químicas das amostras de solo natural, lodo e solo contaminado}

As amostras de solo natural não contaminado, de solo contaminado e de lodo, retiradas no aterro de Botucatu, foram preparadas e analisadas quimicamente no CEPEMA - Centro de Capacitação e Pesquisa em Meio Ambiente do Departamento de Engenharia Química da EPUSP, localizado em Cubatão/SP. A etapa intermediária de digestão ácida com aquecimento, realizada para todas as amostras, foi realizada na Central Analítica do Instituto de Química da USP.

\subsubsection{Preparação das amostras}

As amostras inicialmente foram colocadas em estufa para remoção da umidade (Figura 4-9). Em seguida, as amostras foram destorroadas com almofariz e pistilo de ágata.

O material utilizado foi o passado na peneira de malha $40(0,42 \mathrm{~mm})$ de aço inox, correspondendo às frações areia fina, silte e argila, uma vez que a fração areia também pode ser responsável pela adsorção de poluentes em solos lateríticos, como observado por Boscov $(2010,2011)$ e Lange (2012). 


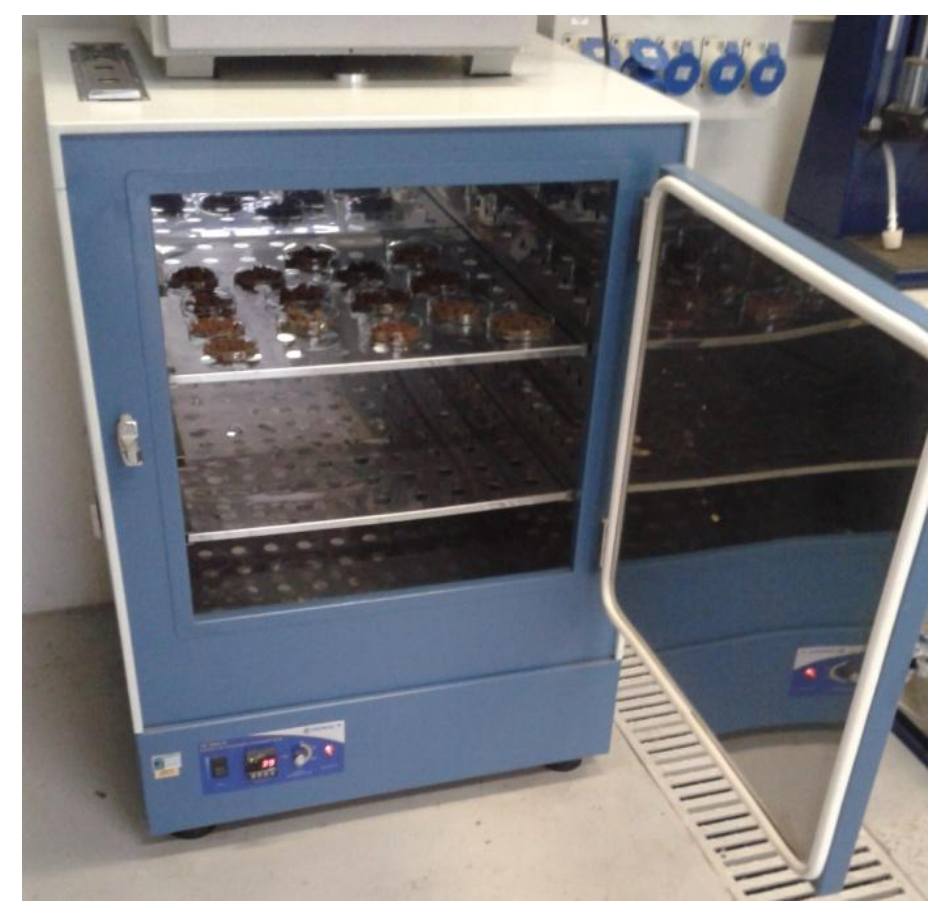

Figura 4-9 - Amostras colocadas em estufa para remoção da umidade.

Para facilitar a digestão ácida, cada amostra foi moída em moinho triturador de bolas de velocidade de 617 golpes/minutos por um tempo de 2 minutos. A aparência das amostras moídas pode ser observada na Figura 4-10.

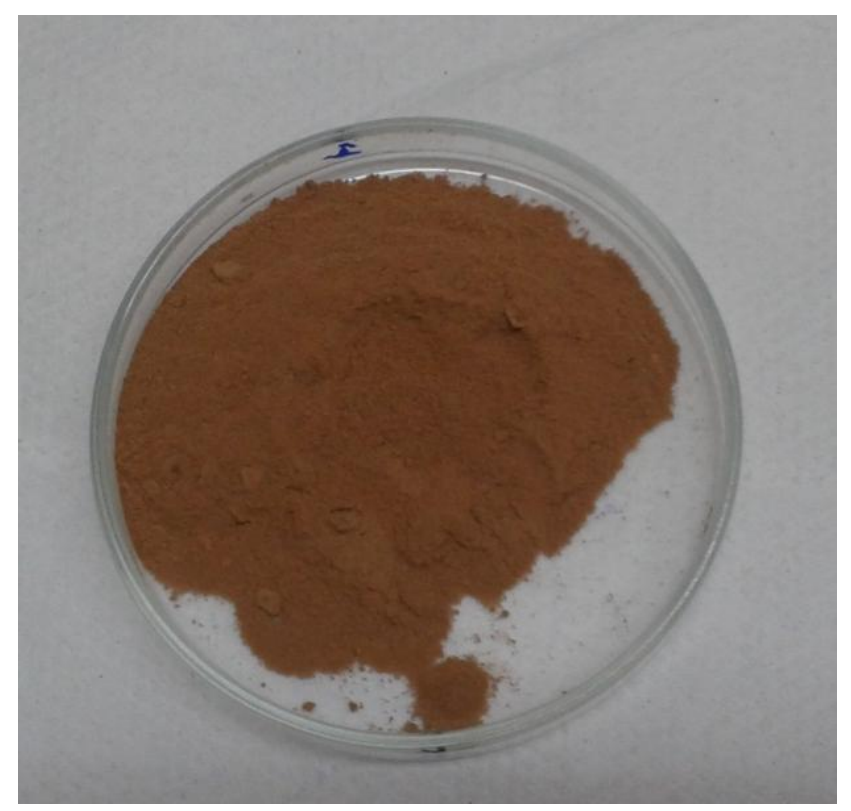

Figura 4-10 - Amostra de solo contaminado após moagem. 


\subsubsection{Digestão ácida}

As amostras foram submetidas à digestão ácida parcial conforme o método EPA 3051A (USEPA, 2007b), com obtenção posterior das concentrações de metais através de espectrometria.

Conforme recomendação do método, não devem ser utilizados mais que $0,500 \mathrm{~g}$ de solo em cada frasco de digestão, aos quais se adicionam $10 \mathrm{~mL}$ de ácido concentrado. A suspensão obtida deve ser submetida à digestão ácida parcial com ácido nítrico $\left(\mathrm{HNO}_{3}\right)$ ou ácido nítrico e clorídrico $(\mathrm{HCl})$, os quais devem ter concentração adequada.

Para os ensaios desta pesquisa utilizaram-se massas entre $0,471 \mathrm{~g} \mathrm{e} 0,503 \mathrm{~g}$ de material preparado, às quais se adicionavam $10 \mathrm{~mL}$ de ácido nítrico a $65 \%$ de concentração, a maior comercialmente disponível.

Primeiramente era colocado o material preparado em frascos de digestão de teflon (Figura 4-11) e a seguir adicionado o ácido, formando uma suspensão. Esta era aquecida em um forno de micro-ondas para laboratório por um período de tempo de 5,5 minutos até atingir a temperatura de $175 \pm 5^{\circ} \mathrm{C}$ e mantida em seguida nesta faixa de temperatura por 4,5 minutos. $O$ aquecimento foi realizado em micro-ondas da fabricante Berghof e modelo Speedwave Four (Figura 4-12); o equipamento não foi calibrado, pois o mesmo possuía controle interno de pressão e temperatura em cada frasco, situação prevista em USEPA (2007b).

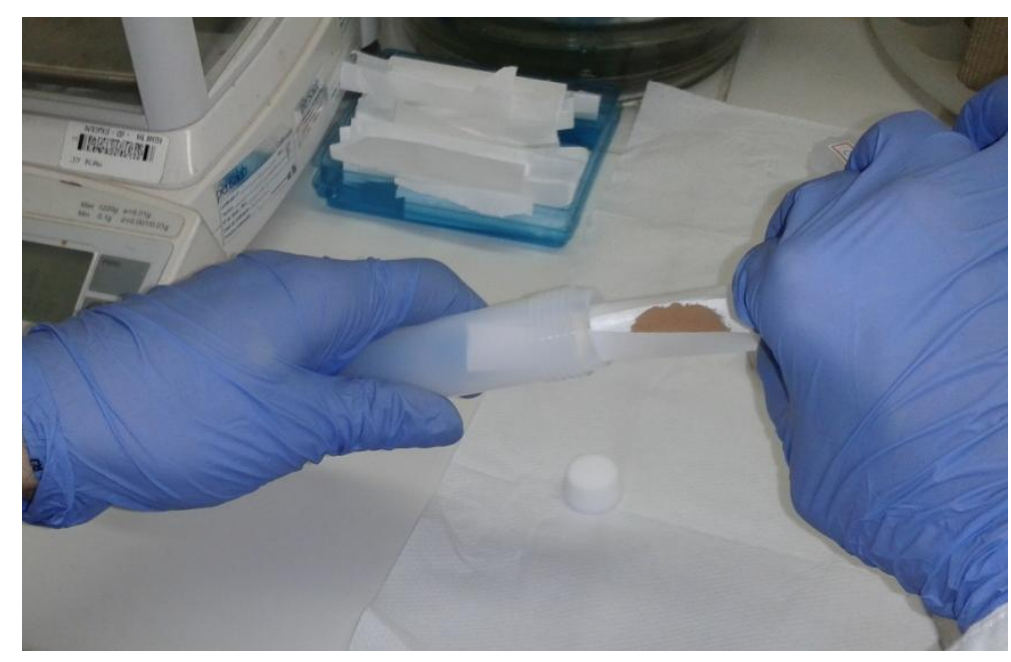

Figura 4-11 - Transferência do material preparado para os frascos digestores. 


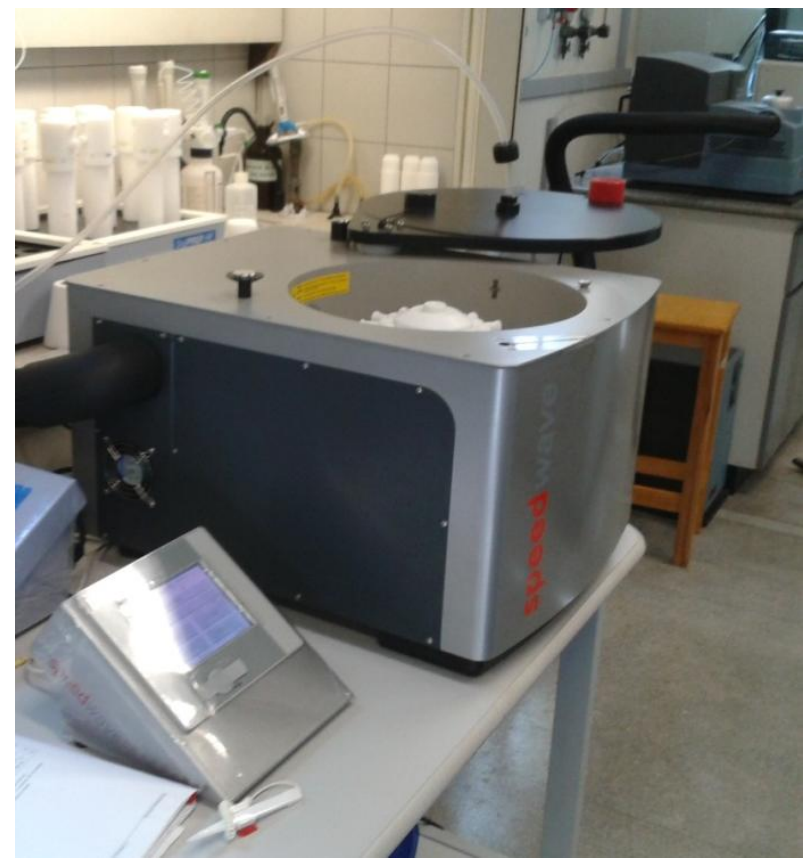

Figura 4-12 - Micro-ondas da fabricante Berghof e modelo Speedwave Four utilizado para o aquecimento das amostras com ácido.

O resfriamento dos frascos após a digestão era executado parcialmente pelo próprio equipamento e finalizado à temperatura ambiente. Após o resfriamento, o conteúdo do recipiente era filtrado em seringa com filtro acoplado de malha $0,22 \mu \mathrm{m}$.

Utilizaram-se triplicatas para cada amostra analisada. Para verificar eventuais interferências de solventes, reagentes e vidrarias, em todas as bateladas de ensaios foram executados brancos de método com um dos recipientes preenchido apenas com $10 \mathrm{~mL}$ de ácido nítrico. Ao todo, foram realizadas 6 bateladas compostas de 11 amostras e 1 branco de análise para cada batelada.

O forno de micro-ondas utilizado foi fabricado especialmente para fins laboratoriais, com estrutura interna para rotação dos frascos digestores (para garantir o aquecimento homogêneo das soluções de cada frasco), resistência à corrosão, sistema de controle e alívio de pressão, e controle interno e sensores de temperatura.

Antes da execução dos primeiros ensaios de digestão das amostras e após cada batelada executada, os frascos digestores foram preenchidos com solução $10 \%$ de ácido nítrico a concentração de $65 \%$ e limpos através da mesma sequência temporal de temperatura utilizada nas amostras de solo. Após o resfriamento dos frascos, as 
soluções internas foram descartadas e aplicou-se água Milli-Q nas superfícies internas dos frascos para remoção de quaisquer partículas restantes.

Para a limpeza dos balões volumétricos, estes foram simplesmente preenchidos com solução $10 \%$ de ácido nítrico a concentração de $65 \%$ por 24 horas, após as quais o ácido era descartado e água Milli-Q era aplicada às superfícies internas. Outros materiais de laboratório utilizados, como espátula e almofariz de ágata, foram limpos com detergente neutro dextran, enxaguados com água destilada, novamente lavados com o detergente e enxaguados com água Milli-Q. Para a secagem, os materiais laboratoriais eram colocados sobre papel toalha, em uma bancada e ambiente limpo, para remoção da umidade.

\subsubsection{Avolumamento das amostras}

A amostra filtrada era transferida diretamente ao balão volumétrico e adicionava-se água Milli-Q para completar o volume nominal do balão, conforme pode ser visualizado na Figura 4-13. A finalidade era obter um volume conhecido de amostra líquida digerida para, por meio da concentração medida no espectrômetro, determinar a massa do elemento estudado extraída da amostra de solo na digestão ácida. Calculava-se então a concentração do elemento por massa seca de amostra.

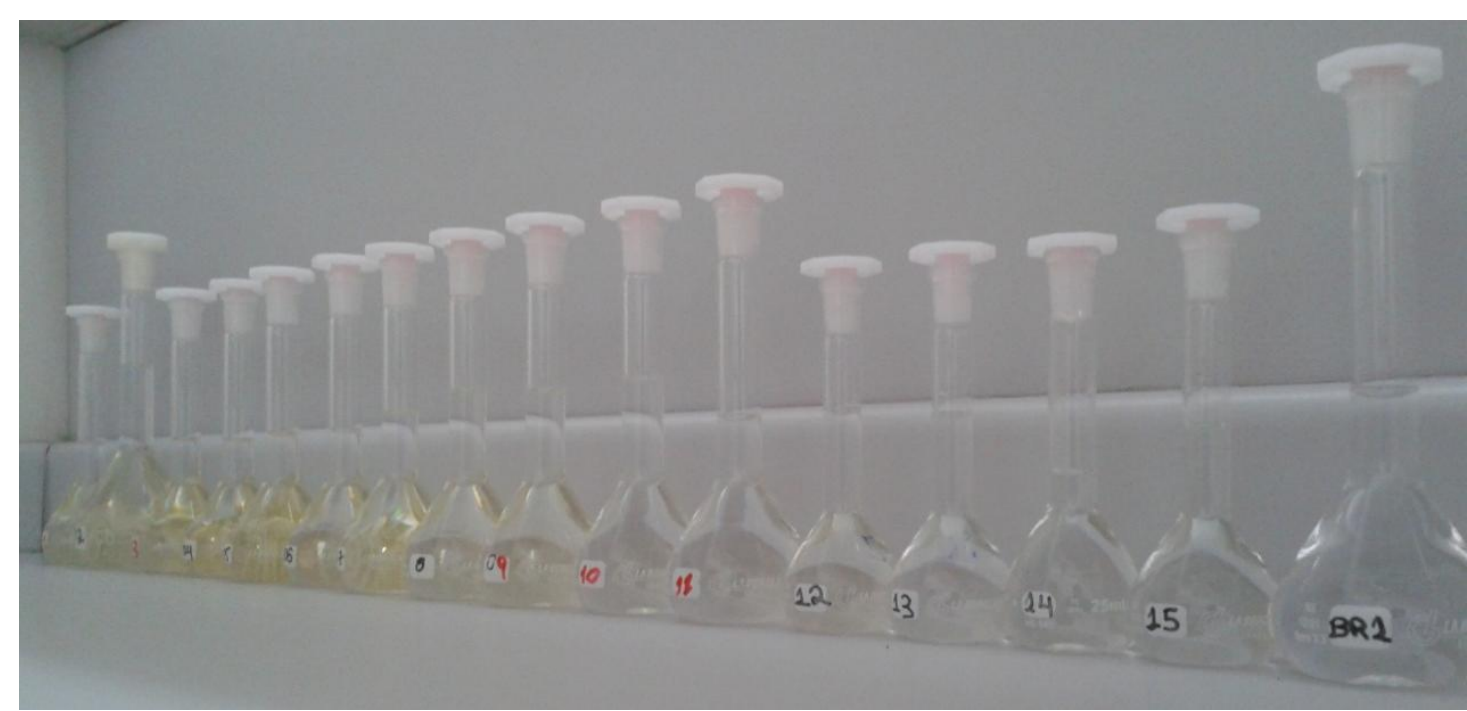

Figura 4-13 - Balões volumétricos preenchidos com amostras de solos após digestão em micro-ondas e branco de análise. 


\subsubsection{Espectrometria}

As determinações quantitativas foram realizadas em um espectrômetro de emissão atômica com plasma induzido (ICP-AES) marca Varian modelo 720-ES (Figura 4-14). Após ligar o equipamento, é necessário liberar a alimentação do gás argônio e é feito o acionamento do plasma da tocha, aguardando a estabilização da mesma. Por cerca de 20 minutos é realizada a purga do argônio no sistema para remoção de impurezas e bolhas.

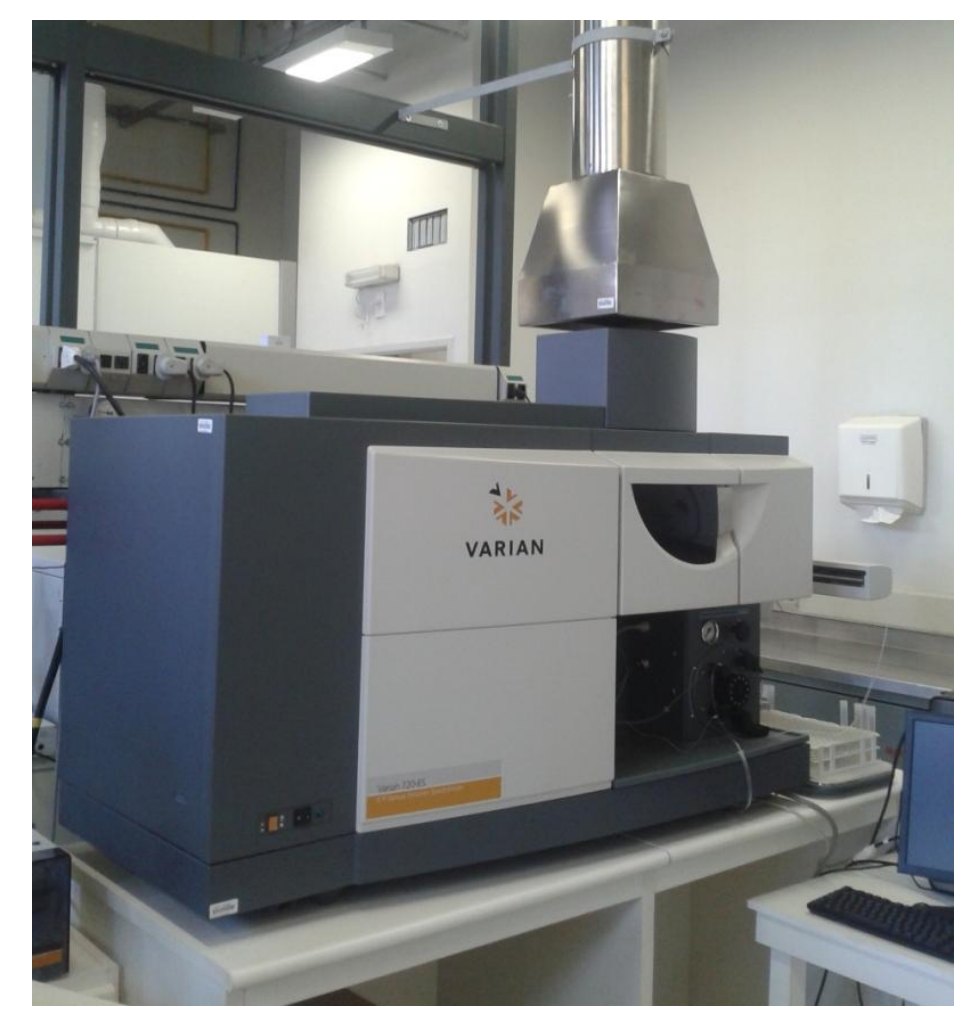

Figura 4-14 - Espectrômetro de emissão atômica com plasma induzido (ICP-AES) marca Varian modelo 720-ES utilizado na determinação das concentrações das soluções digeridas.

Para cada elemento, foram preparadas soluções para calibração das leituras do equipamento com concentrações de 0,2, 5, 10, 30 e 50 ppm, obtidas através de soluções de padrões conhecidos, certificados e rastreáveis da Inorganic Ventures com concentração de 1.000 ppm e avolumadas em balões volumétricos de $25 \mathrm{~mL}$ e $50 \mathrm{~mL}$. Dos valores obtidos eram descontados os respectivos valores dos brancos. 
Os elementos escolhidos foram: arsênio, cádmio, chumbo, cobre, cromo, ferro, manganês, níquel e zinco.

A partir dos resultados obtidos nas primeiras leituras concluiu-se pela necessidade de recalibrar o equipamento, utilizando-se então soluções de concentrações de 0,1 , $3,5,7$ e $10 \mathrm{ppm}$.

\subsection{Análises químicas das amostras líquidas}

Diferentemente do que com as amostras sólidas, as amostras líquidas não necessitaram uma preparação prévia antes da digestão ácida.

Para a digestão ácida, $20 \mathrm{~mL}$ de cada amostra líquida foram transferidos para frascos digestores, aos quais foram adicionados $2,5 \mathrm{~mL}$ de ácido nítrico concentrado. O método USEPA (2007a) preconiza a utilização de $45 \mathrm{~mL}$ de amostra líquida e $5 \mathrm{~mL}$ de ácido concentrado em frascos digestores de $100 \mathrm{~mL}$; porém, como os frascos disponíveis eram de $50 \mathrm{~mL}$, reduziram-se as quantidades em massa proporcionalmente para garantir espaço livre no frasco em caso de fortes reações durante o aquecimento do conteúdo interno de cada frasco. Os frascos eram em seguida devidamente selados e aquecidos no forno de micro-ondas. A temperatura de cada amostra deveria atingir $170 \pm 5^{\circ} \mathrm{C}$ em 10 minutos e permanecer nesta faixa de temperatura por mais 10 minutos. Em cada rodada de aquecimento no forno de micro-ondas, foi utilizado um tubo preenchido com $2,5 \mathrm{~mL}$ de ácido nítrico e $20 \mathrm{~mL}$ de água Milli-Q como branco da rodada. Após o resfriamento, o conteúdo dos frascos foi filtrado.

Os frascos eram então submetidos ao avolumamento e analisados pelo método analítico apropriado, sendo estas duas fases executadas da mesma forma que para as amostras sólidas (itens 4.4 .3 e 4.4.4). A filtração das amostras digeridas foi realizada com filtro de membrana. 


\subsection{Caracterização geotécnica, mineralógica e química do solo natural}

\subsubsection{Caracterização geotécnica}

Os ensaios de caracterização geotécnica, assim como os de permeabilidade e coluna, foram realizados no Laboratório de Mecânica dos Solos da Escola Politécnica da Universidade de São Paulo (LMS-EPUSP).

\subsubsection{Granulometria}

A distribuição granulométrica do solo local foi obtida segundo a NBR 7181 (ABNT, 1988a).

\subsubsection{Densidade dos grãos}

A densidade dos grãos do solo foi obtida segundo a NBR 6508 (ABNT, 1984b).

\subsubsection{Limites de Atterberg}

Os limites de liquidez e plasticidade foram obtidos conforme os procedimentos descritos na NBR 6459 (ABNT, 1984a) e NBR 7180 (ABNT, 1984c), respectivamente.

\subsubsection{Compactação}

A curva e parâmetros de compactação foram obtidos segundo a NBR 7182 (ABNT, 1988b). 


\subsubsection{5 Índice de Vazios e Porosidade}

O índice de vazios e a porosidade do solo natural foram obtidos pelas Equações (12) e (13).

$e=\frac{\gamma_{s}}{\gamma_{d}}-1$

sendo:

e: índice de vazios;

$\gamma_{s}$ : peso específico dos grãos; e

$\gamma_{d}$ : peso específico aparente seco do solo.

$n=\frac{e}{1+e}$

sendo:

$\mathrm{n}$ : porosidade.

O peso específico natural foi obtido de duas maneiras: por meio do método da balança hidrostática segundo NBR 6508 (ABNT, 1984b) e por meio do peso e dimensões dos corpos-de-prova talhados para os ensaios de permeabilidade e coluna.

\subsubsection{Caracterização mineralógica}

A composição mineralógica do solo foi determinada por meio de ensaios de difração de raios $X$, fluorescência de raios $X$ e microscopia eletrônica de varredura, executados no Laboratório de Caracterização Tecnológica da Escola Politécnica da USP (LCT -EPUSP).

Como preparação prévia, as amostras foram secas ao ar ambiente para remoção da umidade e destorroadas em almofariz e com pistilo de ágata. Apenas o material passante na peneira de malha 40 (com abertura normalizada de $0,42 \mathrm{~mm}$ ) foi 
enviado ao LCT-EPUSP; trata-se das frações granulométricas areia fina, silte e argila.

\subsubsection{Caracterização química}

Os ensaios de caracterização química do solo foram realizados no Departamento de Ciência do Solo da Escola Superior de Agricultura Luiz de Queiroz da USP.

A amostra de solo natural não contaminada foi preparada mediante a secagem, homogeneização e passagem da mesma por peneira de malha 10 (abertura de $2 \mathrm{~mm})$.

Foram determinados: acidez potencial $(\mathrm{H}+\mathrm{Al})$, cálcio, carbono orgânico, CTC, fósforo, magnésio, matéria orgânica, pH em água, pH em $\mathrm{KCl}$, potássio, saturação da CTC por bases (V), soma de bases trocáveis e saturação por alumínio $(\mathrm{m})$, pelos métodos EMBRAPA $(1997,1999)$.

\subsection{Ensaios de permeabilidade à água}

Os corpos-de-prova utilizados foram indeformados, ou seja, retirados dos blocos coletados em campo e talhados para execução dos ensaios.

Os ensaios de permeabilidade foram realizados em permeâmetros de carga constante e parede flexível, no aparelho Tri-Flex 2 da ELE Internacional Inc./ Soiltest Products Division, com água de torneira e em ambiente com temperatura controlada de $20 \pm 3^{\circ} \mathrm{C}$. Os corpos-de-prova foram confinados com tensão de $50 \mathrm{KPa}$, e foram aplicados gradientes hidráulicos variando de 2 a 15. Esta tensão confinante corresponde a uma média do confinamento esperado no solo sob a lagoa até a profundidade de $4 \mathrm{~m}$.

Antes do início do ensaio de permeabilidade, com as câmaras do aparelho Tri-Flex preenchidas com água, os corpos-de-prova foram submetidos a adensamento com tensão de $50 \mathrm{KPa}$, com as drenagens de base e topo abertas, até que não houvesse mais saída de água dos vazios do solo. O volume de água de saída foi medido para permitir o cálculo do novo volume de vazios dos corpos-de-prova. 
Finda a etapa de adensamento, foi conectado à base das câmaras do aparelho TriFlex um frasco de Mariotte preenchido com água e iniciado o ensaio de permeabilidade à água (Figura 4-15). A percolação em fluxo ascendente foi escolhida por facilitar a saída de bolhas de ar e, portanto, possibilitar a obtenção de um grau de saturação elevado no corpo-de-prova. O frasco de Mariotte foi utilizado para garantir que o gradiente hidráulico fosse constante ao longo do ensaio. A extremidade inferior do tubo interno foi alinhada horizontalmente com a saída do frasco, e manteve-se durante todo o ensaio o nível d'água dentro do frasco acima da extremidade inferior do tubo interno.

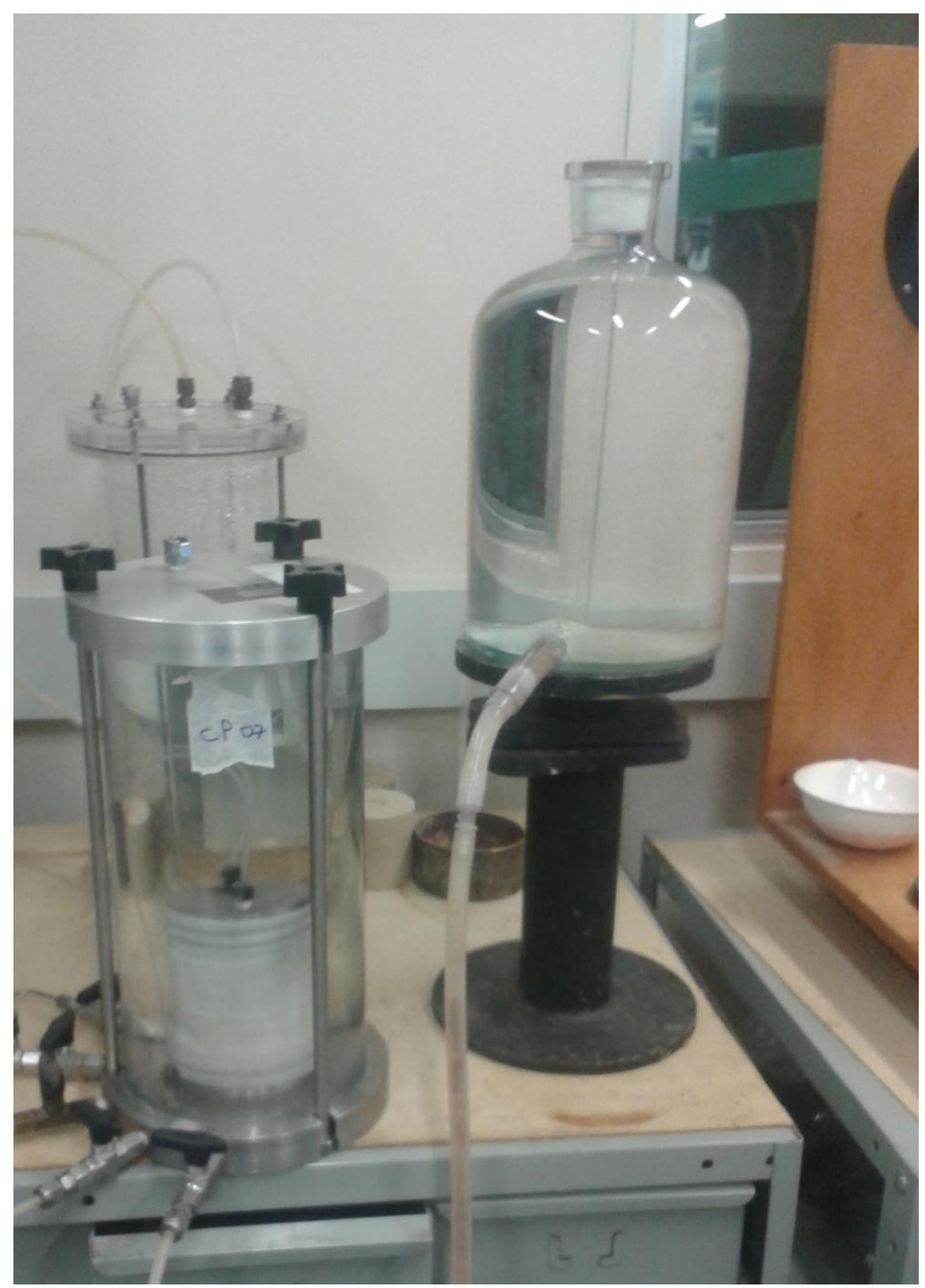

Figura 4-15 - Frasco de Mariotte preenchido com água ao lado de corpo-de-prova em câmara do aparelho Tri-Flex. 
A norma D5084 da American Society for Testing Materials (ASTM, 1990) recomenda que o gradiente hidráulico aplicado a corpos-de-prova de ensaios de permeabilidade sejam escolhidos de acordo com a faixa de condutividade hidráulica (Tabela 4-2) e que a percolação de água seja mantida pelo menos até a obtenção de quatro valores de condutividade hidráulica ao longo de um intervalo de tempo em que: (1) a relação entre a vazão de saída e de entrada situe-se entre 0,75 e 1,25 e (2) a condutividade hidráulica seja estável. A condutividade hidráulica (k) é considerada estável se quatro ou mais determinações consecutivas estiverem dentro do intervalo $\pm 25 \%$ em relação à média das determinações para $\mathrm{k} \geq 1 \times 10^{-10} \mathrm{~m} / \mathrm{s}$ ou dentro do intervalo $\pm 50 \%$ em relação à média das determinações para $\mathrm{k}<1 \times 10^{-10} \mathrm{~m} / \mathrm{s}$, além de que graficamente a condutividade hidráulica em função do tempo não deverá mostrar tendência ascendente ou descendente.

Tabela 4-2 - Gradiente hidráulico recomendado para ensaios de permeabilidade pela ASTM (1990).

\begin{tabular}{|c|c|}
\hline $\begin{array}{c}\text { Condutividade hidráulica } \\
(\mathbf{m} / \mathbf{s})\end{array}$ & $\begin{array}{c}\text { Gradiente hidráulico } \\
\text { recomendado }\end{array}$ \\
\hline $1 \times 10^{-5}$ até $1 \times 10^{-6}$ & 2 \\
\hline $1 \times 10^{-6}$ até $1 \times 10^{-7}$ & 5 \\
\hline $1 \times 10^{-7}$ até $1 \times 10^{-8}$ & 10 \\
\hline $1 \times 10^{-8}$ até $1 \times 10^{-9}$ & 20 \\
\hline Inferior a $1 \times 10^{-9}$ & 30 \\
\hline
\end{tabular}

A norma NBR 14545 (ABNT, 2000) recomenda gradiente hidráulico menor ou igual a 15 para solos argilosos e que o ensaio seja executado até a obtenção de pelo menos quatro determinações de condutividade hidráulica relativamente próximas, as quais não apresentem tendências evidentes de crescimento ou diminuição. Já a norma NBR 13292 (ABNT, 1995), aplicável a ensaios de permeabilidade para solos granulares, não apresenta critério de parada. 


\subsubsection{Ensaios de permeabilidade ao lixiviado}

Os ensaios de permeabilidade ao lixiviado, bem como os de coluna executados conjuntamente, foram executados depois de finalizados os ensaios de permeabilidade à água.

Antes do início dos ensaios de permeabilidade ao lixiviado, os frascos de Mariotte foram preenchidos com lixiviado e a alimentação passou a ser feita pelo topo do corpo-de-prova, em fluxo descendente (Figura 4-16a). O fluxo foi invertido para melhor representar a infiltração do lixiviado no subsolo a partir de um acúmulo na superfície do terreno.

Os frascos foram cobertos com papel alumínio (Figura 4-16b) para minimizar as reações químicas no lixiviado pela incidência de luz.

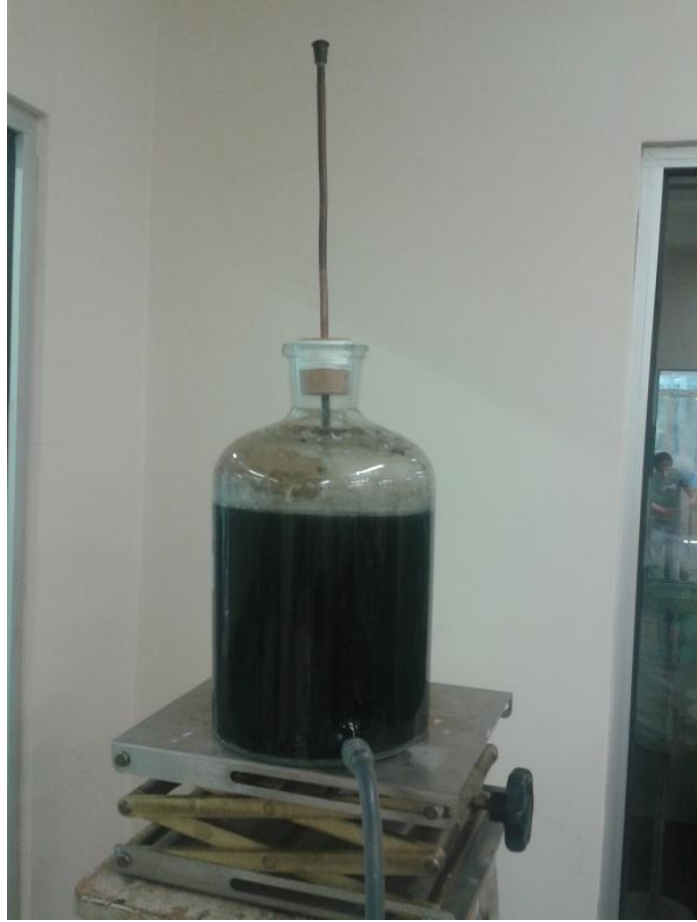

(a)

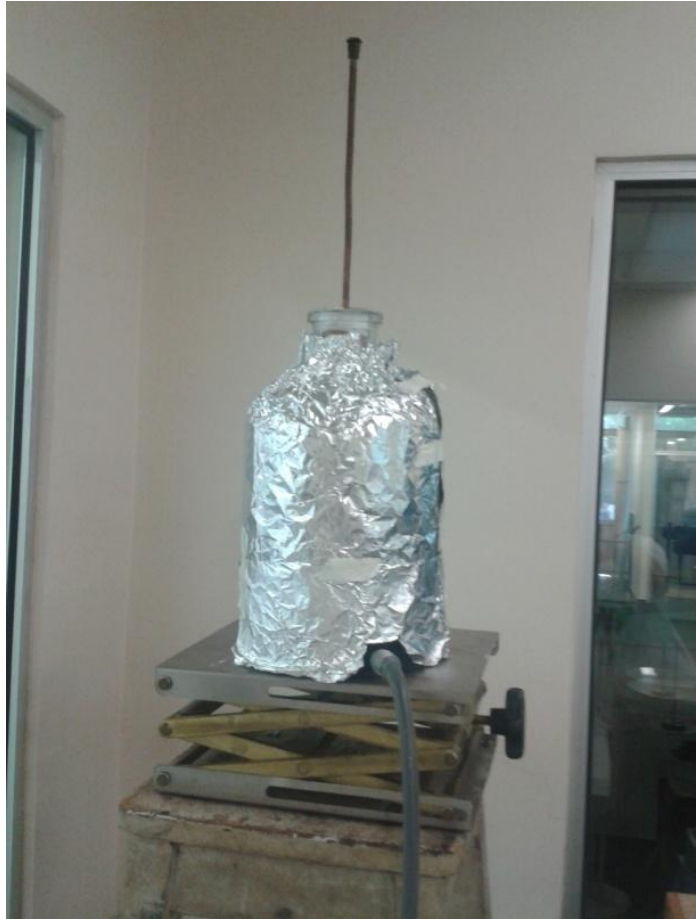

(b)

Figura 4-16 - Frasco de Mariotte: (a) preenchido com lixiviado; (b) coberto com papel alumínio para evitar reações químicas pela incidência de luz no lixiviado. 


\subsubsection{Ensaios de coluna}

Após passar por percolação de água nos ensaios de permeabilidade descritos no item 4.7, os corpos-de-prova foram percolados com lixiviado segundo 0 procedimento do ensaio de coluna descrito em Stuermer et al. (2008).

As variáveis de qualidade e constituintes do lixiviado analisados foram: arsênio, cádmio, COT, chumbo, cloreto, cobre, cromo, ferro, manganês, níquel, NKT e zinco. 


\section{RESULTADOS}

\subsection{Caracterização geotécnica}

\subsubsection{Granulometria}

A distribuição granulométrica do solo local está apresentada na Figura 5-1.

Determinaram-se as seguintes frações granulométricas em massa de solo seco: $8 \%$ de argila, $4 \%$ de silte, $60 \%$ de areia fina e $28 \%$ de areia média. Pode-se observar que a presença de finos é igual a $12 \%$, corroborando a observação de Rodrigues et al. (1993) de que a presença de material fino nas Formações Botucatu e Pirambóia é menor do que $20 \%$.

\subsubsection{Densidade dos grãos}

A densidade dos grãos determinada para o solo estudado foi de $2,685 \mathrm{~g} / \mathrm{cm}^{3}$.

\subsubsection{Limites de Atterberg}

Foram obtidos os seguintes valores de limites de Atterberg: $26 \%$ de limite de liquidez, $16 \%$ de limite de plasticidade e, consequentemente, 10\% de índice de plasticidade. Pelo Sistema Unificado de Classificação de Solos, o solo é uma areia argilosa, SC.

O índice de atividade da fração argila do solo, que é a razão entre o índice de plasticidade e a fração argila, é 1,25, valor considerado normal por Skempton (1953). 


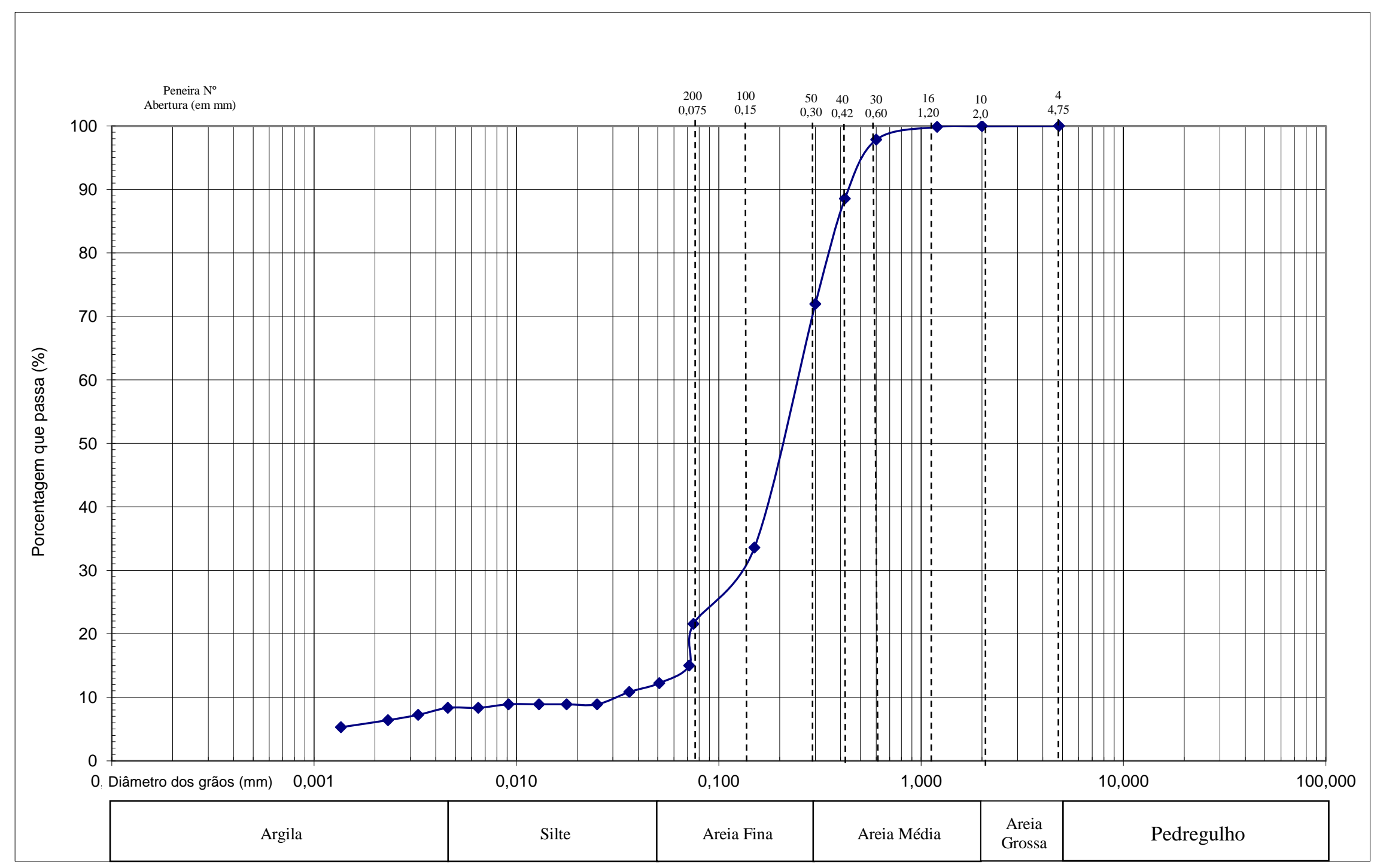

Figura 5-1 - Distribuição granulométrica do solo local típico. 


\subsubsection{Compactação}

A curva de compactação obtida utilizando a energia normal está representada na Figura 5-2. O solo apresenta como parâmetros ótimos de compactação uma densidade seca máxima de $1,86 \mathrm{~g} / \mathrm{cm}^{3}$ (ou peso específico de $18,4 \mathrm{KN} / \mathrm{m}^{3}$ ) e umidade ótima de 14,3\%. Segundo Pinto (2002), areias argilosas lateríticas podem apresentar umidades ótimas de 12 a 14\% com densidades secas máximas de $1,9 \mathrm{~g} / \mathrm{cm}^{3}$.

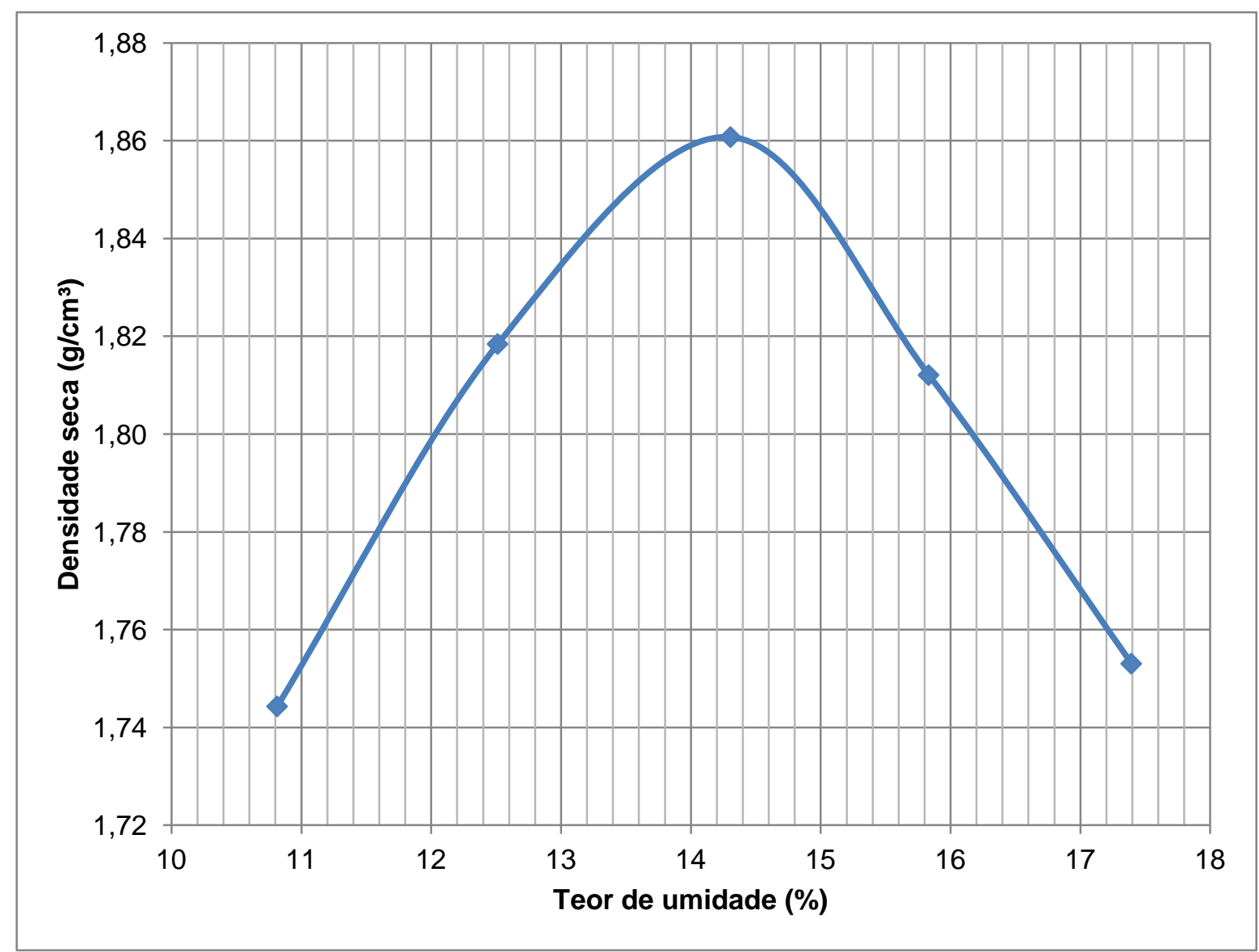

Figura 5-2 - Curva de compactação obtida.

Os valores obtidos também se adéquam à correlação de Bernucci (1995) para solos lateríticos compactados (Equação 12). Para a umidade ótima de $14,3 \%$, o peso específico seco máximo estimado pela correlação é $18,9 \mathrm{kN} / \mathrm{m}^{3}$, ou seja, comparando este valor com o obtido no ensaio de compactação, decorre em um erro de estimativa de $3,3 \%$. 
$\gamma_{d, \max }=22,62-0,26 w_{o t} ; r=-0,96$

sendo:

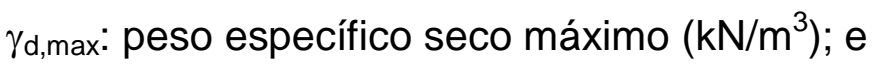

$\mathrm{w}_{\mathrm{ot}}$ : umidade ótima.

\subsection{5 Índice de Vazios e Porosidade}

O índice de vazios e porosidade determinados pelo método da balança hidrostática em um dos blocos indeformados coletados em campo foram de, respectivamente, 0,93 e 0,48 . Estes valores foram confirmados na moldagem dos corpos-de-prova para ensaios de permeabilidade, antes da etapa de adensamento dos corpos-deprova (vide item 5.4), para os quais o índice de vazios variou entre 0,84 e 0,97, e a porosidade, entre 0,46 e 0,49 .

\subsection{Caracterização mineralógica}

O resultado da identificação de fases cristalinas por difratometria de raios $X$, apresentado na Figura 5-3, mostrou a ocorrência dos minerais quartzo $\left(\mathrm{SiO}_{2}\right)$, caulinita $\left(\mathrm{Al}_{2}\left(\mathrm{Si}_{2} \mathrm{O}_{5}\right)(\mathrm{OH})_{4}\right)$, gibbsita $\left(\mathrm{Al}(\mathrm{OH})_{3}\right)$ e hematita $\left(\mathrm{Fe}_{2} \mathrm{O}_{3}\right)$; constatou-se a possibilidade da presença de anatásio $\left(\mathrm{TiO}_{2}\right)$.

Na Figura 5-4 é exposto o difratograma obtido, onde são assinaladas as linhas de difração correspondentes às fases identificadas, sendo que cada fase está representada por uma cor distinta.

Foram obtidas imagens de microscopia eletrônica de varredura (MEV), algumas das quais estão apresentadas na Figura 5-5 e na Figura 5-6. Essas imagens mostram a predominância de óxidos de silício, de alumínio, de ferro e de titânio, podendo ser associados à presença dos seguintes minerais, respectivamente: quartzo e caulinita, caulinita e gibbsita, hematita, e anatásio. 


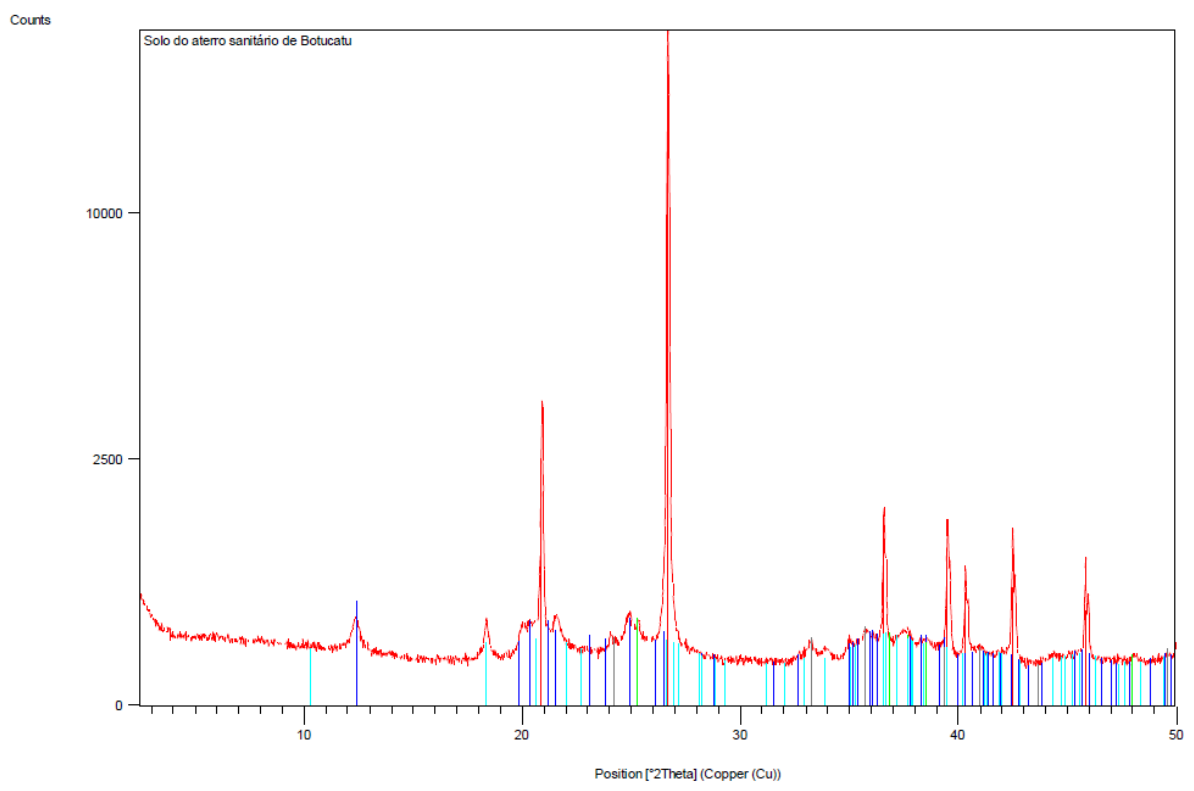

Figura 5-3 - Resultado do ensaio de difratometria de raios $X$.

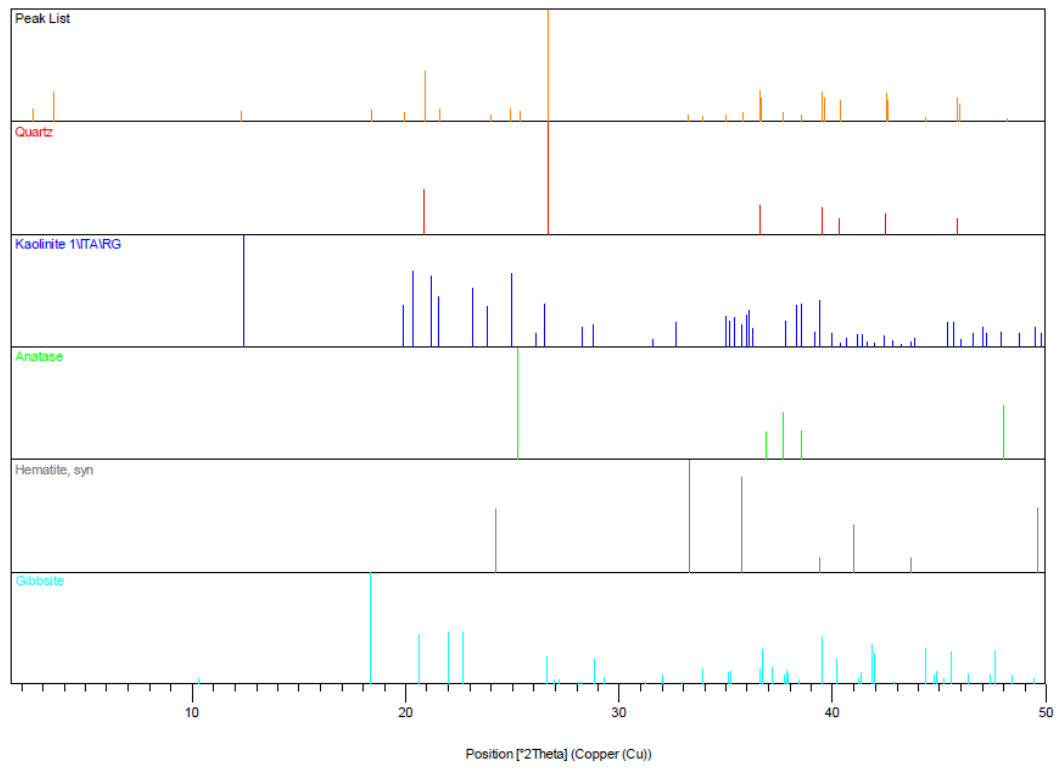

Figura 5-4 - Fases identificadas no difratograma de raio $X$. 


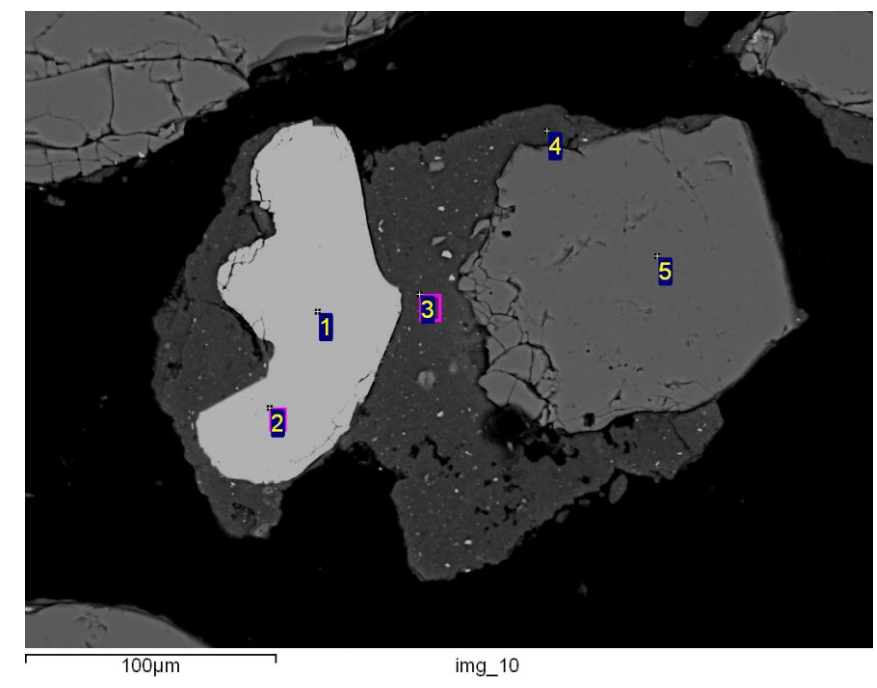

Figura 5-5 - Minerais encontrados durante a realização da MEV (predominância de 1 e 2: $\mathrm{TiO}_{2}$ e $\mathrm{Fe}_{2} \mathrm{O}_{3} ; 3: \mathrm{Al}_{2} \mathrm{O}_{3}, \mathrm{SiO}_{2}$ e $\mathrm{Fe}_{2} \mathrm{O}_{3} ; 4: \mathrm{Al}_{2} \mathrm{O}_{3}, \mathrm{SiO}_{2}$ e $\mathrm{Fe}_{2} \mathrm{O}_{3} ;$ 5: $\mathrm{SiO}_{2}$ ).

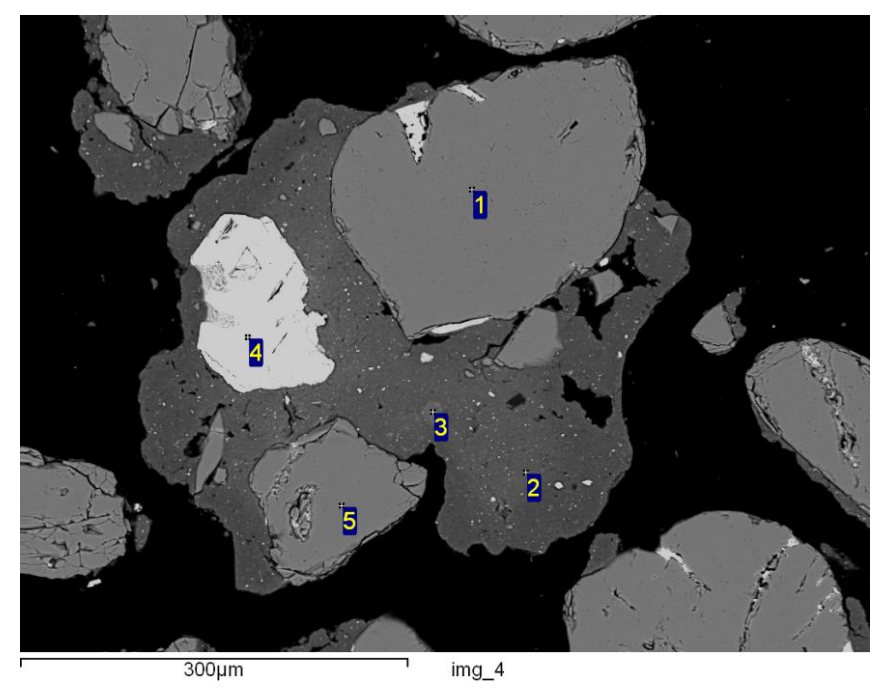

Figura 5-6 - Minerais encontrados durante a realização da MEV (predominância de 1: $\mathrm{SiO}_{2} ; 2: \mathrm{Al}_{2} \mathrm{O}_{3}, \mathrm{SiO}_{2}$ e $\mathrm{Fe}_{2} \mathrm{O}_{3} ; 3: \mathrm{SiO}_{2}, \mathrm{Al}_{2} \mathrm{O}_{3}$, e $\mathrm{Fe}_{2} \mathrm{O}_{3} ; 4: \mathrm{Fe}_{2} \mathrm{O}_{3}$ e $\mathrm{TiO}_{2} ; 5: \mathrm{SiO}_{2}$ ).

\subsection{Caracterização química}

A análise química semiquantitativa por fluorescência de raios $X$ detectou os compostos químicos e seus respectivos teores presentes expostos na Tabela 5-1. O resultado foi coerente com a caracterização mineralógica, haja vista a predominância de silício, alumínio, ferro e titânio. Pode-se observar a presença de diversos outros elementos químicos, os quais estão presentes em pequenas quantidades. 
Tabela 5-1 - Resultado da análise química semiquantitativa do solo.

\begin{tabular}{|c|c|c|c|}
\hline $\begin{array}{c}\text { Composto } \\
\text { Químico }\end{array}$ & $\begin{array}{c}\text { Teor Normalizado do Composto } \\
\text { Químico (\%) }\end{array}$ & $\begin{array}{c}\text { Composto } \\
\text { Químico }\end{array}$ & $\begin{array}{c}\text { Teor Normalizado do } \\
\text { Composto Químico (\%) }\end{array}$ \\
\hline $\mathrm{MgO}$ & 0,04 & $\mathrm{MnO}$ & 0,03 \\
\hline $\mathrm{Al}_{2} \mathrm{O}_{3}$ & 16,5 & $\mathrm{Fe}_{2} \mathrm{O}_{3}$ & 7,17 \\
\hline $\mathrm{SiO}_{2}$ & 68,1 & $\mathrm{NiO}$ & 0,01 \\
\hline $\mathrm{P}_{2} \mathrm{O}_{5}$ & 0,05 & $\mathrm{CuO}$ & 0,04 \\
\hline $\mathrm{SO}_{3}$ & 0,02 & $\mathrm{ZnO}$ & 0,01 \\
\hline $\mathrm{Cl}$ & 0,01 & $\mathrm{Y}_{2} \mathrm{O}_{3}$ & $<<$ \\
\hline $\mathrm{K}_{2} \mathrm{O}$ & 0,04 & $\mathrm{ZrO}_{2}$ & 0,07 \\
\hline $\mathrm{CaO}$ & 0,02 & $\mathrm{Nb}_{2} \mathrm{O}_{5}$ & 0,02 \\
\hline $\mathrm{TiO}_{2}$ & 1,55 & $\mathrm{Ta}_{2} \mathrm{O}_{5}$ & 0,06 \\
\hline $\mathrm{V}_{2} \mathrm{O}_{5}$ & 0,03 & $\mathrm{PbO}_{2}$ & 0,01 \\
\hline $\mathrm{Cr}_{2} \mathrm{O}_{3}$ & 0,08 & $\mathrm{PF}$ & 6,11 \\
\hline
\end{tabular}

$<<$ : teor menor que 0,01\%; PF: perda ao fogo.

Outras características químicas do solo estudado estão apresentadas na Tabela 5-2.

Tabela 5-2- Resultado das análises químicas do solo.

\begin{tabular}{|c|c|}
\hline $\mathrm{pH}\left(\mathrm{em} \mathrm{H} \mathrm{H}_{2} \mathrm{O}\right)$ & 5,7 \\
\hline $\mathrm{pH}$ (em solução de $\mathrm{KCl} 1 \mathrm{~mol} \cdot \mathrm{L}^{-1}$ ) & 4,4 \\
\hline$P\left(m g \cdot K^{-1}\right)$ & $<1$ \\
\hline $\mathrm{K}\left(\mathrm{mmol}_{\mathrm{c}} \cdot \mathrm{kg}^{-1}\right)$ & $<0,3$ \\
\hline $\mathrm{Ca}\left(\mathrm{mmolc} . \mathrm{kg}^{-1}\right)$ & $<2$ \\
\hline $\mathrm{Mg}\left(\mathrm{mmolc} . \mathrm{kg}^{-1}\right)$ & 1 \\
\hline $\mathrm{Al}\left(\mathrm{mmolc} . \mathrm{kg}^{-1}\right)$ & 3 \\
\hline $\mathrm{H}^{+}+\mathrm{Al}^{3+}\left(\right.$ mmolc.kg $\left.{ }^{-1}\right)$ & 22 \\
\hline Soma de bases trocáveis $\left(\mathrm{mmolc} . \mathrm{kg}^{-1}\right)$ & 1,8 \\
\hline CTC (mmolc. $\left.\mathrm{kg}^{-1}\right)$ & 23,4 \\
\hline Saturação da CTC por bases & 8 \\
\hline Saturação por alumínio (\%) & 65 \\
\hline Matéria orgânica $(\mathrm{g} / \mathrm{Kg})$ & 7 \\
\hline Carbono orgânico $(\mathrm{g} / \mathrm{Kg})$ & 4 \\
\hline
\end{tabular}

A fração argila do solo é considerada de baixa atividade: segundo IBGE (2007), valores de capacidade de troca catiônica inferiores a 270 mmolc. $\mathrm{kg}^{-1}\left(27 \mathrm{cmolc} . \mathrm{kg}^{-1}\right)$ de argila caracterizam o solo como de baixa atividade, enquanto valores iguais ou superiores indicam alta atividade. Fadigas et al. (2002), analisando 162 solos 
brasileiros argilosos, observaram que a CTC era menor do que 100 mmolc. $\mathrm{kg}^{-1}$ para $79 \%$ dos solos, e do que 200 mmolc. $\mathrm{kg}^{-1}$ para 96\% dos solos. Melfi et al. (2004) também mostraram grande predominância de solos com CTC inferior a 100 mmolc. $\mathrm{kg}^{-1}$ no território brasileiro.

O teor de matéria orgânica é baixo, mas coerente com dados de solos brasileiros: Fadigas et al. (2002) obtiveram teor de matéria orgânica menor do que $20 \mathrm{~g} / \mathrm{kg}$ para $91 \%$ das amostras dos 162 solos argilosos pesquisados.

O solo é moderadamente ácido ( $\mathrm{pH}$ entre 5,4 e 6,5) segundo a classificação do IBGE (2007). Solos tropicais são geralmente ácidos (NOGAMI; VILLIBOR, 1995). Fadigas et al. (2002) observaram que $89 \%$ dos 162 solos argilosos pesquisados tinham $\mathrm{pH} \leq 6$ e $60 \%, \mathrm{pH} \leq 5$.

A carga líquida do solo foi estimada pela Equação 13. O valor de $\Delta \mathrm{pH}$ negativo, igual a $-1,3$, indica a predominância de cargas superficiais negativas, ou seja, o solo é mais propício à adsorção de cátions.

$\Delta p H=p H_{K C l}-p H_{H_{2} O}$

O ponto de carga zero (PCZ) foi estimado como 3,1 pela Equação 14. Como o pH do solo é maior do que o $\mathrm{PCZ}$, há predominância de cargas negativas no solo, sejam elas permanentes e/ou variáveis (MELO \& ALLEONI, 2009 apud LANGE, 2012).

$P C Z=2 p H_{K C l}-p H_{H_{2} O}$

Leite (2001) estudou cinco materiais do mesmo grupo geológico investigado nesta pesquisa: um solo argiloso da Formação Serra Geral, um solo arenoso da formação Botucatu e três misturas desses solos lateríticos. O autor observou que o valor estimado de PCZ pela relação expressa na Equação 14 foi menor do que o obtido por titulação potenciométrica para o solo da Formação Botucatu e para as misturas, sendo maior para o solo da Formação Serra Geral. No caso do solo da Formação Botucatu, a estimativa foi próxima do valor determinado em ensaio (erro de 5\%), enquanto para os demais materiais observaram-se erros entre $15 \%$ e $24 \%$. 
Hemsi et al. (2002), por outro lado, determinaram valores de PCZ por titulação potenciométrica entre 4 e 4,5 para uma argila laterítica residual de diabásio de Campinas/SP, enquanto a relação expressa na Equação 14 estima o valor de 3,9.

\subsection{Ensaios de permeabilidade à água}

Os dados de moldagem dos corpos-de-prova, os índices de vazios no estado natural, os índices de vazios após a etapa de adensamento e os gradientes utilizados nos ensaios de permeabilidade estão apresentados na Tabela 5-3.

Tabela 5-3- Dados dos corpos-de-prova submetidos a ensaios de permeabilidade.

\begin{tabular}{|c|c|c|c|c|c|}
\hline $\begin{array}{c}\text { Corpo de } \\
\text { Prova }\end{array}$ & $\begin{array}{c}\text { Altura } \\
(\mathrm{cm})\end{array}$ & $\begin{array}{c}\text { Diâmetro } \\
(\mathrm{cm})\end{array}$ & $\begin{array}{c}\text { Índice de } \\
\text { Vazios } \\
\text { Natural }\end{array}$ & $\begin{array}{c}\text { Índice de Vazios } \\
\text { após } \\
\text { Adensamento }\end{array}$ & $\begin{array}{c}\text { Gradientes } \\
\text { Hidráulicos } \\
\text { Aplicados }\end{array}$ \\
\hline CP 01 & 6,01 & 7,05 & 0,95 & 0,87 & 30 \\
\hline CP 03 & 7,04 & 6,96 & 0,84 & 0,83 & 5 \\
\hline CP 05 & 7,51 & 6,90 & 0,97 & 0,88 & 5,10 e 15 \\
\hline CP 06 & 7,33 & 6,91 & 0,95 & 0,89 & $2,5,10$ e 15 \\
\hline
\end{tabular}

Os resultados dos ensaios de permeabilidade, apresentados em curvas de condutividade hidráulica em função do volume de água percolado (expresso em número de volumes de vazios), estão apresentados da Figura 5-7 à Figura 5-10.

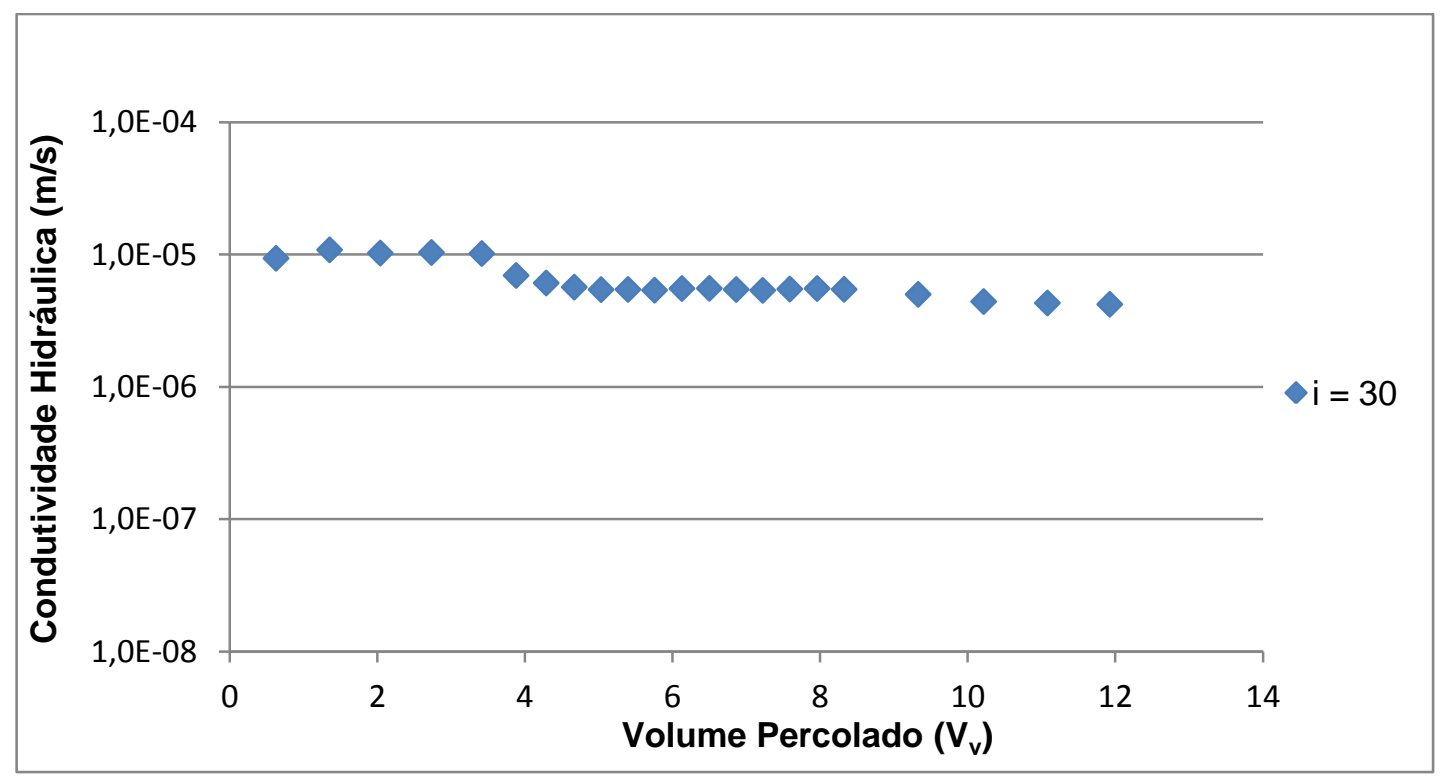

Figura 5-7 - Ensaio de permeabilidade à água do corpo-de-prova CP 01. 


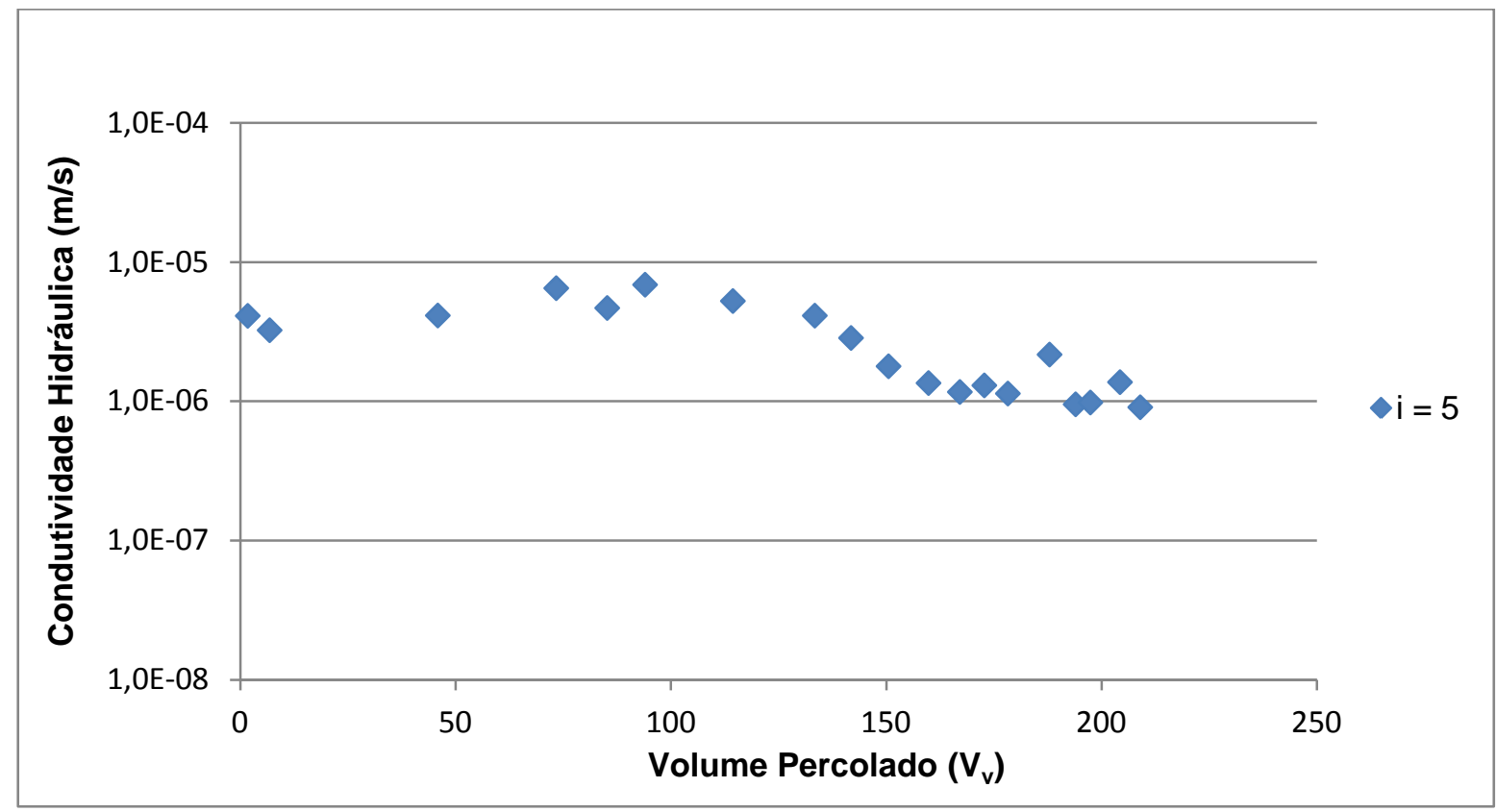

Figura 5-8 - Ensaio de permeabilidade à água do corpo-de-prova CP 03.

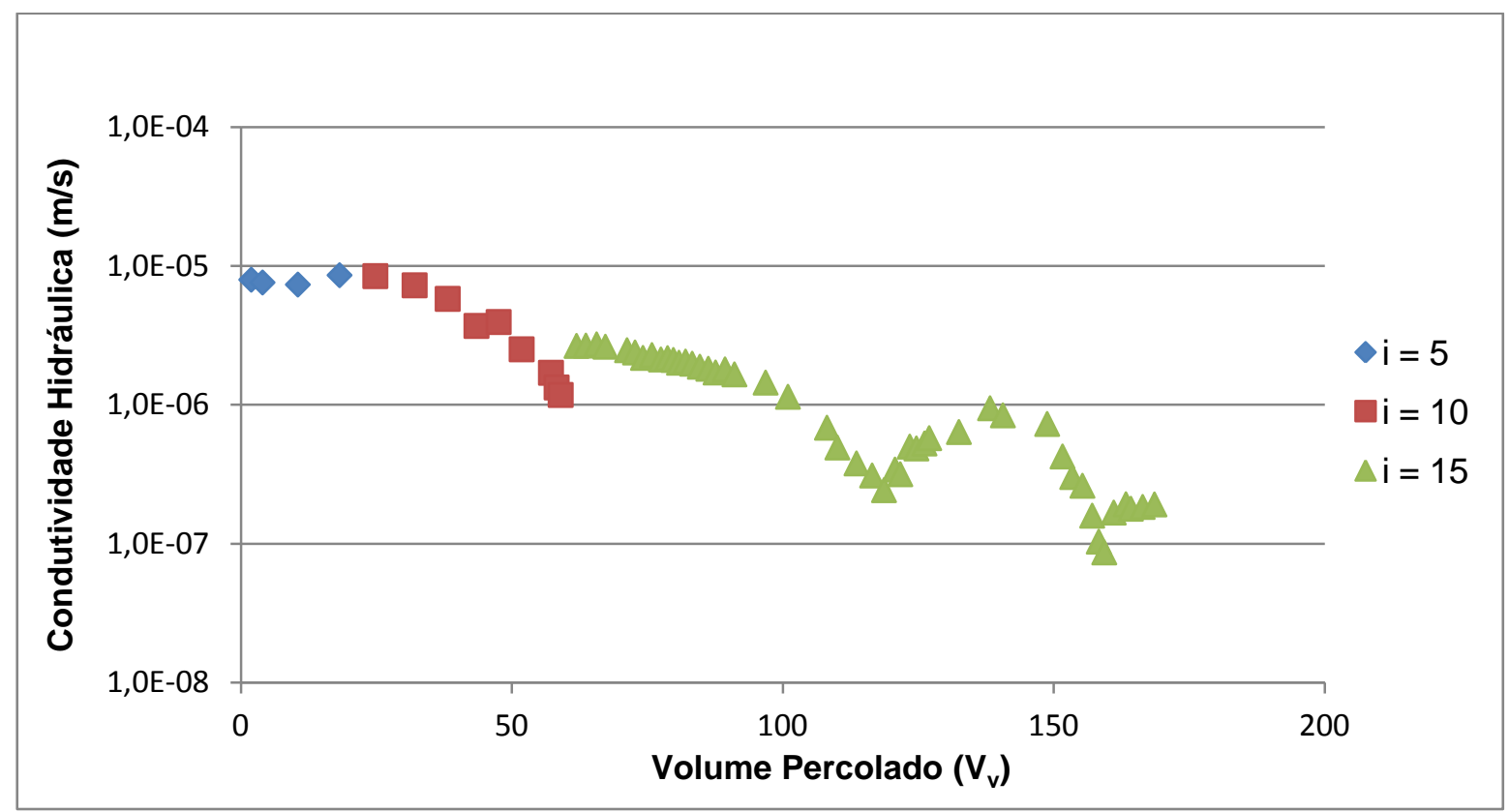

Figura 5-9 - Ensaio de permeabilidade à água do corpo-de-prova 05. 


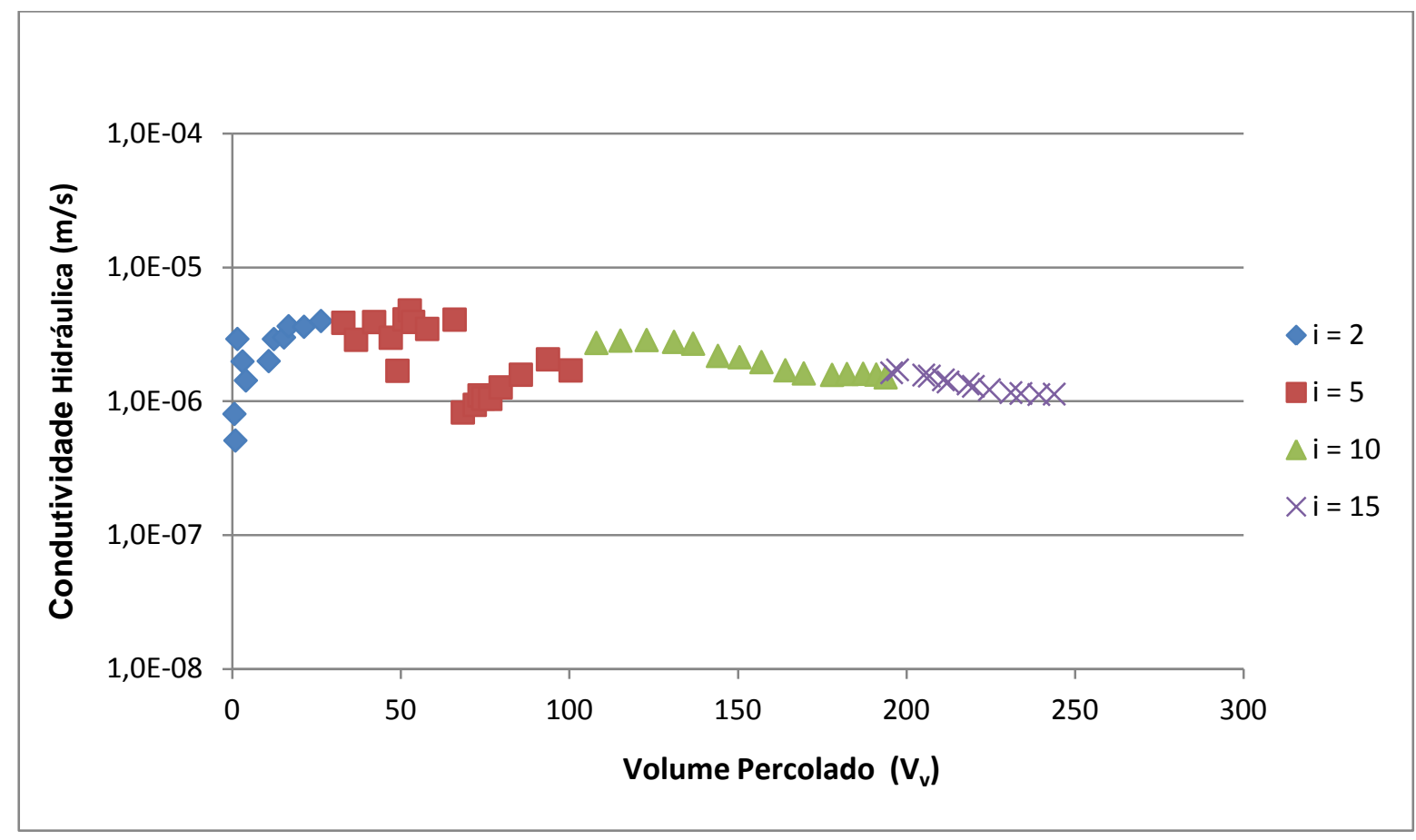

Figura 5-10 - Ensaio de permeabilidade à água do corpo-de-prova CP 06.

O resumo dos ensaios de permeabilidade está apresentado na Tabela 5-4.

Tabela 5-4 - Resumo dos ensaios de permeabilidade à água.

\begin{tabular}{|c|c|c|c|c|c|c|c|}
\hline $\begin{array}{c}\text { Corpo } \\
\text { de } \\
\text { Prova }\end{array}$ & $\begin{array}{c}\text { Gradiente } \\
\text { Hidráulico } \\
\text { Aplicado }\end{array}$ & $\begin{array}{l}\text { Condutividade } \\
\text { Hidráulica após } \\
\text { Percolação de } \\
2 \mathrm{~V}_{\mathrm{v}}(\mathrm{m} / \mathrm{s})\end{array}$ & $\begin{array}{c}\text { Condutividade } \\
\text { Hidráulica } \\
\text { Final }(\mathrm{m} / \mathrm{s})\end{array}$ & $\begin{array}{l}\text { Tempo de } \\
\text { Percolação } \\
\text { (horas) }\end{array}$ & $\begin{array}{l}\text { Tempo } \\
\text { Total de } \\
\text { Percolação } \\
\text { (horas) }\end{array}$ & $\begin{array}{l}\text { Volume de } \\
\text { Vazios de } \\
\text { Água } \\
\text { Percolado } \\
\quad\left(\mathrm{V}_{\mathrm{v}}\right)\end{array}$ & $\begin{array}{c}\text { Total de } \\
\text { Volume } \\
\text { de Vazios } \\
\text { de Água } \\
\text { Percolado } \\
\left(\mathrm{V}_{\mathrm{v}}\right)\end{array}$ \\
\hline CP 01 & 30 & $1,0 \times 10^{-5}$ & $4,2 \times 10^{-6}$ & 0,5 & 1 & 12 & 12 \\
\hline CP 03 & 5 & $4,0 \times 10^{-6}$ & $9,0 \times 10^{-7}$ & 145 & 145 & 209 & 209 \\
\hline \multirow{3}{*}{ СР 05} & 5 & $7,9 \times 10^{-6}$ & $8,6 \times 10^{-6}$ & 4 & \multirow{3}{*}{149} & 18 & \multirow{3}{*}{169} \\
\hline & 10 & $8,4 \times 10^{-6}$ & $1,2 \times 10^{-6}$ & 11 & & 41 & \\
\hline & 15 & $2,7 \times 10^{-6}$ & $1,9 \times 10^{-7}$ & 135 & & 110 & \\
\hline \multirow{4}{*}{ CP 06} & 2 & $2,9 \times 10^{-6}$ & $4,0 \times 10^{-6}$ & 50 & \multirow{4}{*}{184} & 26 & \multirow{4}{*}{244} \\
\hline & 5 & $3,8 \times 10^{-6}$ & $1,7 \times 10^{-6}$ & 68 & & 74 & \\
\hline & 10 & $2,7 \times 10^{-6}$ & $1,5 \times 10^{-6}$ & 43 & & 93 & \\
\hline & 15 & $1,6 \times 10^{-6}$ & $1,1 \times 10^{-6}$ & 24 & & 50 & \\
\hline
\end{tabular}

Os corpos-de-prova CP 01 e CP 03 foram submetidos a apenas um valor de gradiente hidráulico durante os ensaios de permeabilidade. Para o CP 01, submetido a um gradiente igual a 30, a condutividade hidráulica diminuiu, durante o ensaio, menos de uma ordem de grandeza e atingiu ao final do ensaio um valor de $4,2 \times 10^{-6} \mathrm{~m} / \mathrm{s}$; para o CP 03, submetido a um gradiente igual a 5 , a condutividade 
hidráulica variou cerca de uma ordem de grandeza e atingiu valor de $9,0 \times 10^{-7} \mathrm{~m} / \mathrm{s}$ no final do ensaio.

Nos ensaios com os corpos-de-prova CP 05 e CP 06 o gradiente hidráulico foi aumentado de maneira progressiva durante o ensaio. O CP 05 foi submetido a gradientes de 5, 10 e 15, atingindo valores finais de condutividade hidráulica de, respectivamente, $8,6 \times 10^{-6} \mathrm{~m} / \mathrm{s}, 1,2 \times 10^{-6} \mathrm{~m} / \mathrm{s}$ e $1,9 \times 10^{-7} \mathrm{~m} / \mathrm{s}$; a condutividade hidráulica sofreu, portanto, uma diminuição de 45 vezes quando o gradiente hidráulico foi triplicado. Já o corpo-de-prova CP 06, submetido a gradientes de 2, 5, 10 e 15, apresentou valores finais de condutividade hidráulica de, respectivamente, $4,0 \times 10^{-6} \mathrm{~m} / \mathrm{s}, 1,7 \times 10^{-6} \mathrm{~m} / \mathrm{s}, 1,5 \times 10^{-6} \mathrm{~m} / \mathrm{s}$ e $1,1 \times 10^{-6} \mathrm{~m} / \mathrm{s}$, ou seja, um decréscimo de condutividade hidráulica inferior a 4 vezes para um aumento de 7,5 vezes no gradiente hidráulico.

Comparando-se a condutividade hidráulica determinada em ensaios com diferentes corpos-de-prova, para valores de gradiente hidráulico de mesmo valor, observa-se que: para o gradiente igual a 5 , os valores obtidos foram $9 \times 10^{-7} \mathrm{~m} / \mathrm{s}$ (CP 03), $8,6 \times 10^{-7} \mathrm{~m} / \mathrm{s}(\mathrm{CP} 05)$ e $1,7 \times 10^{-6} \mathrm{~m} / \mathrm{s}$ (CP 06); para o gradiente igual a 10 , $1,2 \times 10^{-6} \mathrm{~m} / \mathrm{s}(\mathrm{CP} 05)$ e $1,5 \times 10^{-6} \mathrm{~m} / \mathrm{s}$ (CP 06); e para o gradiente igual a 15 , $1,9 \times 10^{-7} \mathrm{~m} / \mathrm{s}$ (CP 05) e $1,1 \times 10^{-6} \mathrm{~m} / \mathrm{s}$ (CP 06).

Para os gradientes 5 e 10, os valores de condutividade hidráulica determinados com diferentes corpos-de-prova foram muito próximos. Para gradiente de 15, a diferença entre as condutividades hidráulicas obtidas de dois corpos-de-prova, de uma ordem de grandeza, pode ser explicada pela diferença na duração dos ensaios. Observa-se que a condutividade hidráulica diminui com o tempo em todos os ensaios; no ensaio com o corpo-de-prova CP 05, houve percolação de um volume de água igual 110 volumes de vazios durante 135 horas, enquanto no corpo-deprova CP 06 houve percolação de 24 volumes de vazios de água em 50 horas, analisando o período em que ambos os corpos de prova foram submetidos a gradiente hidráulico igual a 15. Se o ensaio com o CP 05 e gradiente igual a 15 tivesse sido interrompido após a passagem de 24 volumes de vazios de água, a condutividade hidráulica obtida teria sido da ordem de $1,0 \times 10^{-6} \mathrm{~m} / \mathrm{s}$, igual à do CP 06. 
Se fosse utilizado o critério de parada para ensaios de permeabilidade de Peirce e Witter (1986) e de Bowders et al. (1986), de percolação equivalente a, respectivamente, um volume de vazios e dois volumes de vazios, a condutividade hidráulica teria variado entre $1,6 \times 10^{-6} \mathrm{~m} / \mathrm{s}$ e $1,0 \times 10^{-5} \mathrm{~m} / \mathrm{s}$, considerando-se todos os corpos-de-prova ensaiados e gradientes aplicados.

Atenta-se assim para a necessidade de discutir no meio técnico os critérios de parada de ensaios de permeabilidade e de coluna, assim como de procurar uma normalização que auxilie a comparação entre diferentes pesquisas e que atenda aos requisitos de projetos geoambientais.

A norma ASTM (1990) recomenda que, para solos como o estudado nesta dissertação (condutividade hidráulica da ordem de $1 \times 10^{-6} \mathrm{~m} / \mathrm{s}$ ), o gradiente utilizado seja igual a 5. Na situação de campo o gradiente, na maioria das situações, é ainda menor. Aplicando-se gradientes maiores, os resultados indicam que há mudança na estrutura do solo. A explicação mais plausível é que a elevada velocidade de percolação acarreta adensamento do solo. Outra hipótese é que, sob gradientes elevados, ocorra arraste das partículas mais finas, que podem se acumular nos vazios na base do corpo-de-prova ou no papel filtro e colaborar para a diminuição na condutividade hidráulica ao longo do tempo do ensaio. O solo natural é muito poroso e pode não se mostrar internamente estável sob gradientes elevados.

\subsection{Ensaios de permeabilidade ao lixiviado}

Os ensaios de permeabilidade ao lixiviado foram iniciados como sequência dos ensaios de permeabilidade à água, utilizando-se os mesmos corpos-de-prova e trocando-se o líquido afluente.

As curvas de condutividade hidráulica em função do volume de lixiviado percolado (expresso em número de volumes de vazios) estão apresentadas da Figura 5-11 à Figura 5-14. O resumo dos ensaios de permeabilidade ao lixiviado está apresentado na Tabela 5-5. 


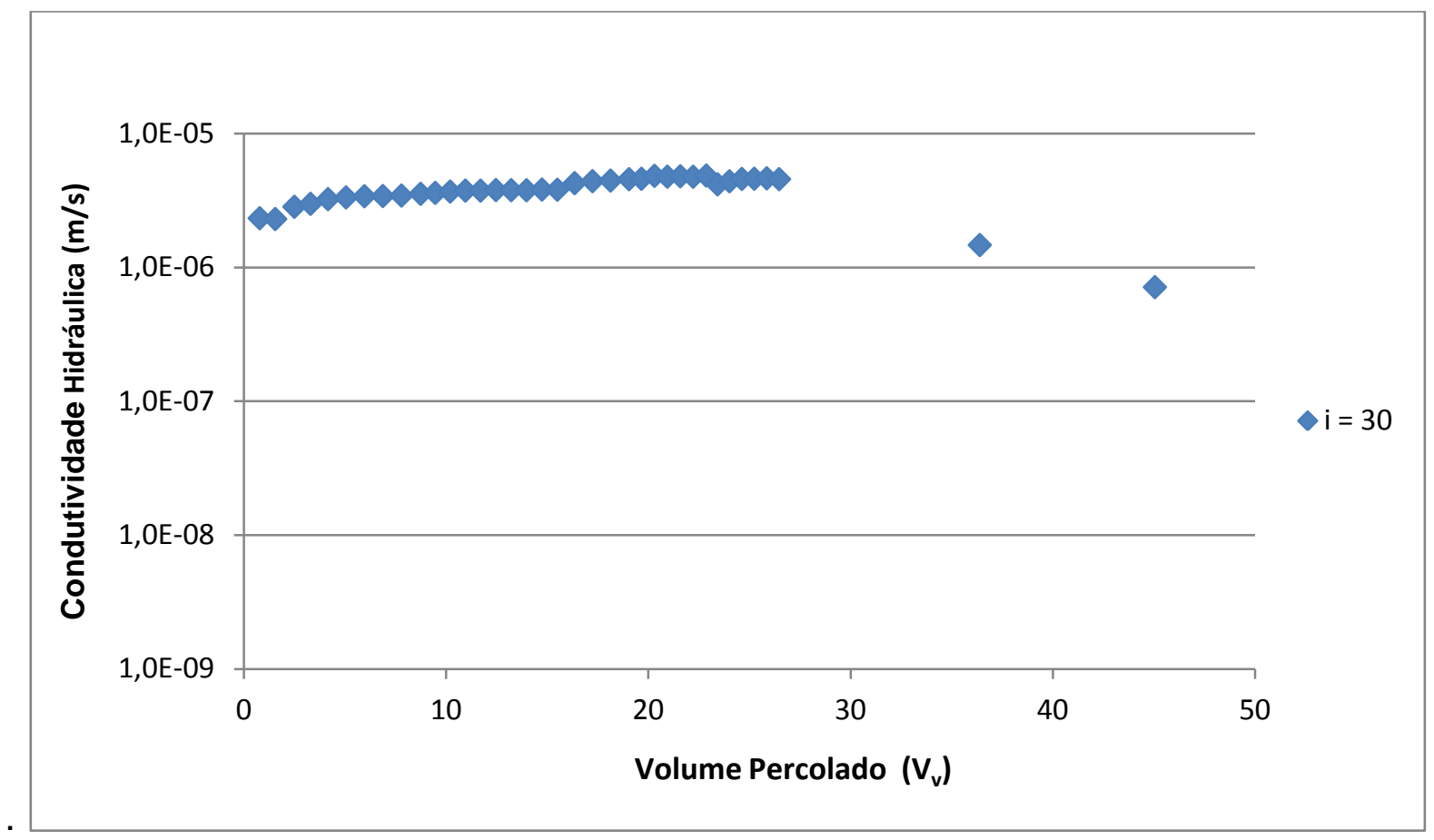

Figura 5-11 - Ensaio de permeabilidade ao lixiviado do corpo-de-prova CP 01.

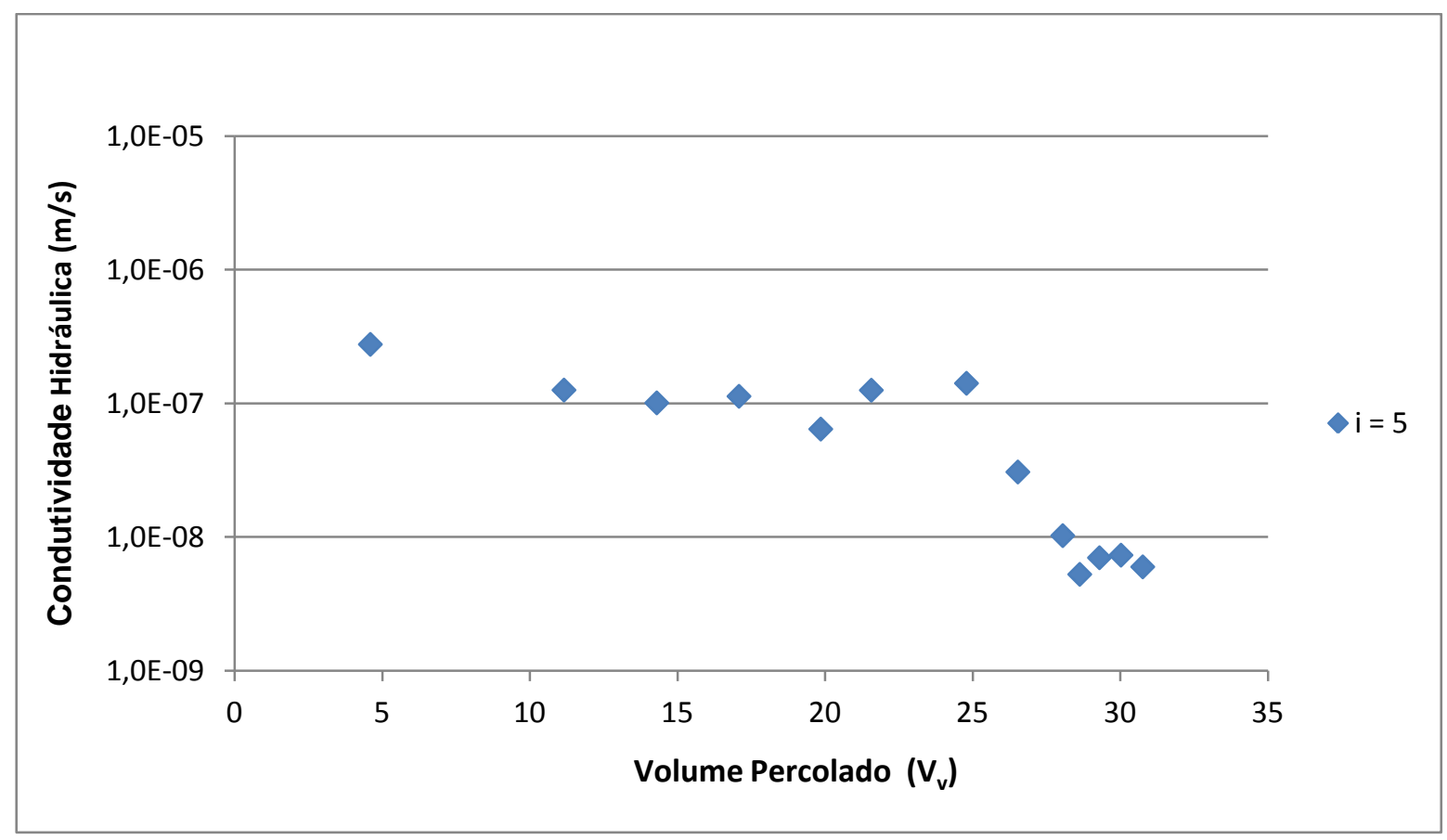

Figura 5-12 - Ensaio de permeabilidade ao lixiviado do corpo-de-prova CP 03. 


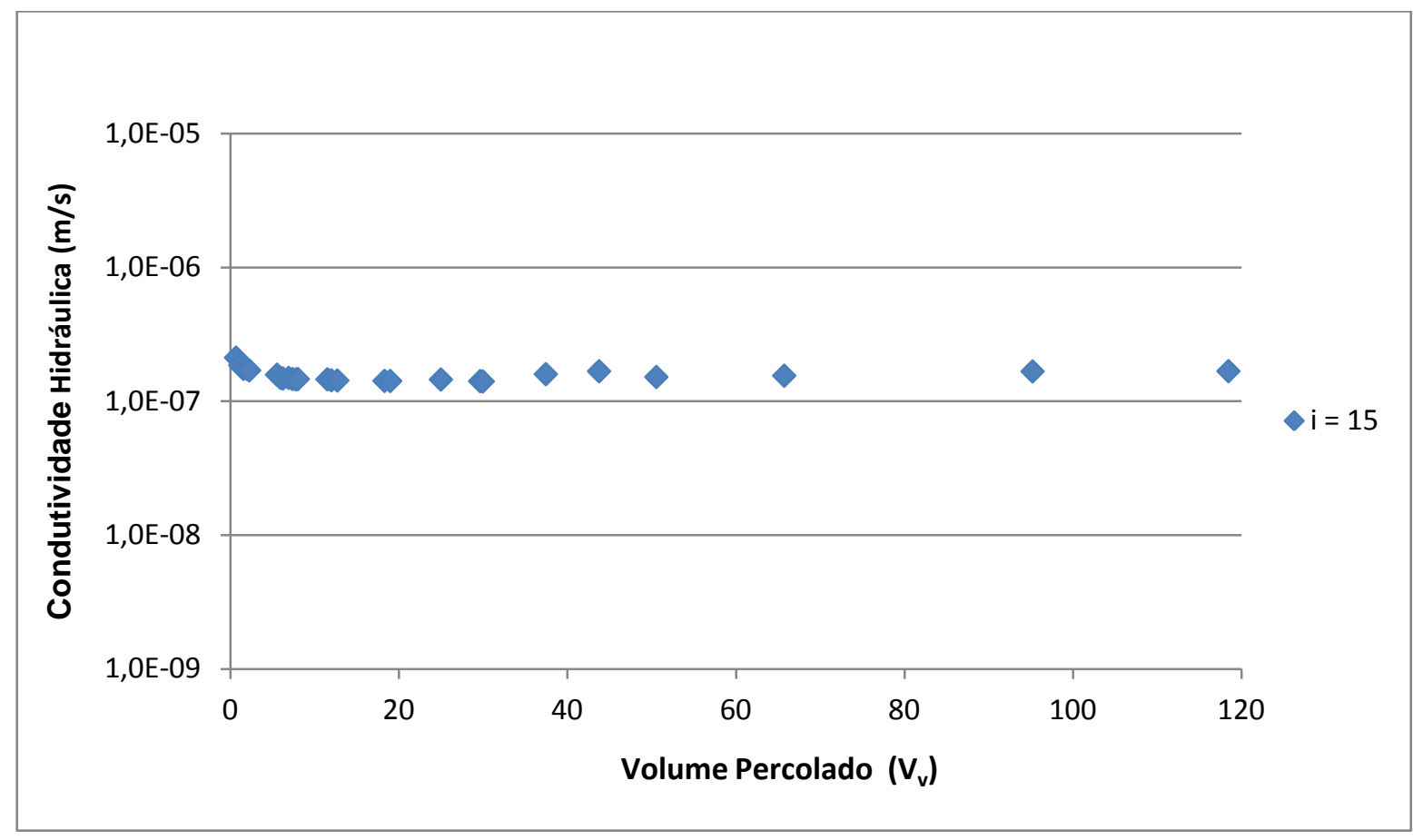

Figura 5-13 - Ensaio de permeabilidade ao lixiviado do corpo-de-prova CP 05.

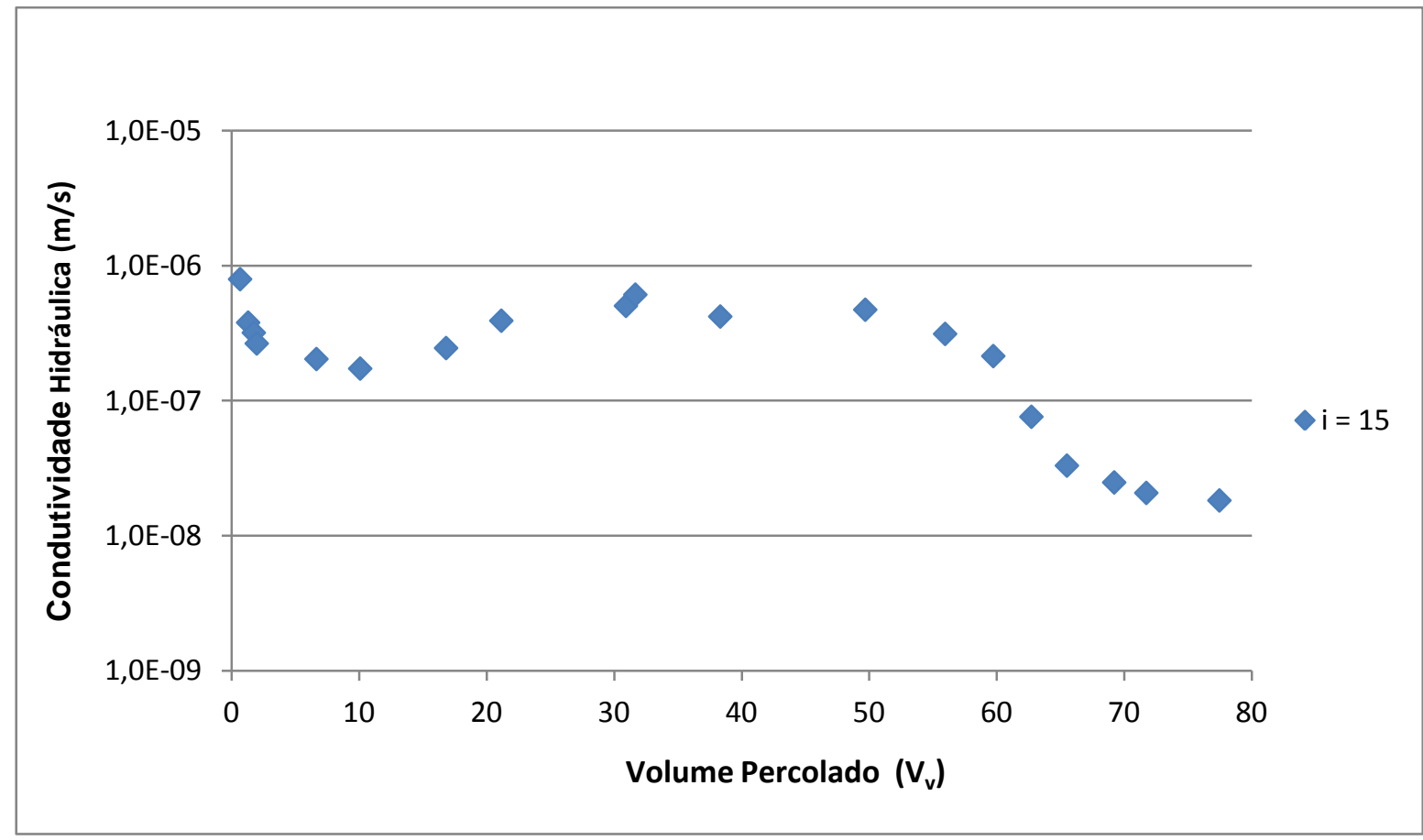

Figura 5-14 Ensaio de permeabilidade ao lixiviado do corpo-de-prova CP 06. 
Tabela 5-5 - Resumo dos ensaios de permeabilidade ao lixiviado.

\begin{tabular}{|c|c|c|c|c|c|}
\hline $\begin{array}{c}\text { Corpo } \\
\text { de } \\
\text { Prova }\end{array}$ & $\begin{array}{c}\text { Gradiente } \\
\text { Hidráulico } \\
\text { Aplicado }\end{array}$ & $\begin{array}{c}\text { Condutividade } \\
\text { Hidráulica após } \\
\text { Percolação de } \\
2 \mathrm{~V}_{\mathrm{v}}(\mathrm{m} / \mathrm{s})\end{array}$ & $\begin{array}{c}\text { Condutividade } \\
\text { Hidráulica } \\
\text { Final }(\mathrm{m} / \mathrm{s})\end{array}$ & $\begin{array}{c}\text { Tempo Total de } \\
\text { Percolação } \\
\text { (horas) }\end{array}$ & $\begin{array}{c}\text { Volume de Vazios } \\
\text { de Lixiviado } \\
\text { Percolado } \\
\left(\mathrm{V}_{\mathrm{v}}\right)\end{array}$ \\
\hline CP 01 & 30 & $2,8 \times 10^{-6}$ & $7,1 \times 10^{-7}$ & 53 & 45 \\
\hline CP 03 & 5 & $2,8 \times 10^{-7}$ & $6,0 \times 10^{-9}$ & 1295 & 31 \\
\hline CP 05 & 15 & $1,7 \times 10^{-7}$ & $1,7 \times 10^{-7}$ & 462 & 118 \\
\hline CP 06 & 15 & $2,7 \times 10^{-7}$ & $1,8 \times 10^{-8}$ & 554 & 77 \\
\hline
\end{tabular}

No ensaio com o corpo-de-prova CP 01 , a condutividade hidráulica, que era $4,2 \times 10^{-6} \mathrm{~m} / \mathrm{s}$ para a água, decresceu para $7,1 \times 10^{-7} \mathrm{~m} / \mathrm{s}$ quando o fluido percolante passou a ser o lixiviado do aterro sanitário, valor de condutividade ainda elevado. O líquido efluente em pouco tempo mostrou-se visualmente com coloração próxima à do lixiviado. $\mathrm{O}$ gradiente hidráulico de 30 aplicado no CP 01 é muito elevado, considerando-se as configurações usuais dos aterros sanitários, portanto realizaramse novos ensaios com gradientes menores.

No ensaio com o corpo-de-prova CP 03, a condutividade hidráulica decresceu cerca de duas ordens de grandeza até o valor de $6,0 \times 10^{-9} \mathrm{~m} / \mathrm{s}$ com a percolação do lixiviado. Após ter sido percolado um volume de lixiviado equivalente a 31 volumes de vazios sob gradiente hidráulico igual a 5 , cessou a percolação. Mesmo com a aplicação do mesmo valor de gradiente hidráulico, não houve vazão efluente. Aumentando-se o gradiente de 5 para 13, restabeleceu-se a percolação de lixiviado pelo corpo-de-prova.

Concluiu-se que, dependendo do gradiente aplicado, pode ocorrer colmatação do corpo-de-prova, ou seja, os vazios do solo podem ser obstruídos pelos constituintes do lixiviado, os quais podem se depositar na superfície dos grãos e nos poros do solo. Assim, para os corpos-de-prova CP 05 e CP 06, decidiu-se utilizar um gradiente hidráulico de valor igual ou superior àquele em que foi reestabelecida a percolação no CP 03, escolhendo-se assim o gradiente igual a 15.

Para o corpo-de-prova CP 05 , submetido a um gradiente igual a 15 , a condutividade hidráulica praticamente não variou durante o ensaio e atingiu valor final de $1,7 \times 10^{-7} \mathrm{~m} / \mathrm{s}$. Para o corpo-de-prova CP 06 , submetido a um gradiente igual a 15 , a condutividade hidráulica oscilou entre o valor inicial de $8,0 \times 10^{-7} \mathrm{~m} / \mathrm{s}$ a $4,7 \times 10^{-7} \mathrm{~m} / \mathrm{s}$ 
até a percolação de um volume de lixiviado equivalente a 50 volumes de vazios; a partir daí, a condutividade hidráulica diminuiu significativamente, atingindo o valor final 1,8 × $10^{-8} \mathrm{~m} / \mathrm{s}$ após a percolação de cerca de mais 30 volumes de vazios.

Verifica-se que a condutividade hidráulica ao lixiviado foi significativamente inferior à condutividade hidráulica à água para os corpos-de-prova CP 01, CP 03 e CP 06, enquanto para o corpo-de-prova CP 05 a condutividade hidráulica foi praticamente a mesma para os dois fluidos.

\subsection{Ensaios de coluna}

Nos ensaios de permeabilidade ao lixiviado determinou-se a composição química do lixiviado (afluente) e foram coletadas e analisadas quimicamente as amostras efluentes, configurando um ensaio de coluna.

Os resultados do ensaio com o corpo-de-prova CP 01 não foram utilizados, pois houve falha no procedimento de coleta das amostras efluentes. Os resultados do corpo-de-prova CP 03 tampouco foram considerados devido à colmatação ocorrida durante o ensaio.

No corpo-de-prova CP 05 foi utilizado lixiviado coletado em janeiro de 2013 e no corpo-de-prova CP 06, em março de 2013. Na Tabela 5-6 apresentam-se as concentrações dos elementos estudados nas duas amostras de lixiviado, a faixa de valores mais prováveis encontrados por Souto e Povinelli (2007) em aterros sanitários brasileiros, os valores de intervenção para águas subterrâneas no Estado de São Paulo (CETESB, 2005) e os valores máximos estabelecidos em nível nacional (CONAMA, 2009).

Em relação à comparação com os valores de intervenção para águas subterrâneas da CETESB (2005) e CONAMA (2009), o lixiviado de janeiro de 2013 apresentou concentrações de chumbo e cromo acima dos valores máximos permitidos, enquanto o lixiviado de março de 2013 apresentou 5 dos 9 elementos investigados em concentrações superiores aos limites. Desta forma, conclui-se que lixiviado de aterro sanitário tem significativo potencial poluidor e o transporte de contaminantes deve ser estudado. 
Tabela 5-6 - Composição química do lixiviado.

\begin{tabular}{|c|c|c|c|c|c|}
\hline \multirow{2}{*}{ Elemento } & \multicolumn{5}{|c|}{ Concentração (mg/L) } \\
\cline { 2 - 6 } & $\begin{array}{c}\text { Lixiviado de } \\
\text { janeiro/2013 }\end{array}$ & $\begin{array}{c}\text { Lixiviado de } \\
\text { março/2013 }\end{array}$ & $\begin{array}{c}\text { Souto e } \\
\text { Povinelli } \\
(2007)\end{array}$ & $\begin{array}{c}\text { CETESB } \\
(2005)\end{array}$ & $\begin{array}{c}\text { CONAMA } \\
(2009)\end{array}$ \\
\hline Arsênio & 0,0029 & 0,0316 & - & 0,01 & 0,01 \\
\hline Cádmio & 0,0031 & 0,0174 & $0-0,065$ & 0,005 & 0,005 \\
\hline Chumbo & 0,0785 & 0,0234 & $0,01-0,5$ & 0,01 & 0,01 \\
\hline Cobre & 0,0523 & 0,0075 & $0,05-$ & 2 & 2 \\
\hline Cromo & 3,6849 & 0,018 & $0,003-$ & 0,05 & 0,05 \\
\hline Ferro & 0,18 & 15,6 & 0,0165 & 0,3 & 2,45 \\
\hline Manganês & 0,107 & 0,315 & $0,04-2,0$ & 0,4 & 0,4 \\
\hline Níquel & 0,001 & 0,0711 & $0,03-0,5$ & 0,07 & 0,02 \\
\hline Zinco & 0 & 0 & $0,01-1,5$ & 5 & 1,05 \\
\hline Cloreto & 800 & 1200 & $500-$ & Não há & Não há \\
\hline COT & 1.410 & 2.885 & - & Não há & Não há \\
\hline NKT & 213 & 224 & $80-3.100$ & Não há & Não há \\
\hline
\end{tabular}

Para os corpos-de-prova CP 05 e CP 06, as concentrações dos elementos arsênio, cádmio, chumbo, cobre, cromo, ferro, manganês, níquel e zinco nas amostras efluentes em função do volume percolado de lixiviado estão apresentadas da Figura 5-15 à Figura 5-23. Nas figuras estão apresentados também os valores das concentrações dos metais no lixiviado. 

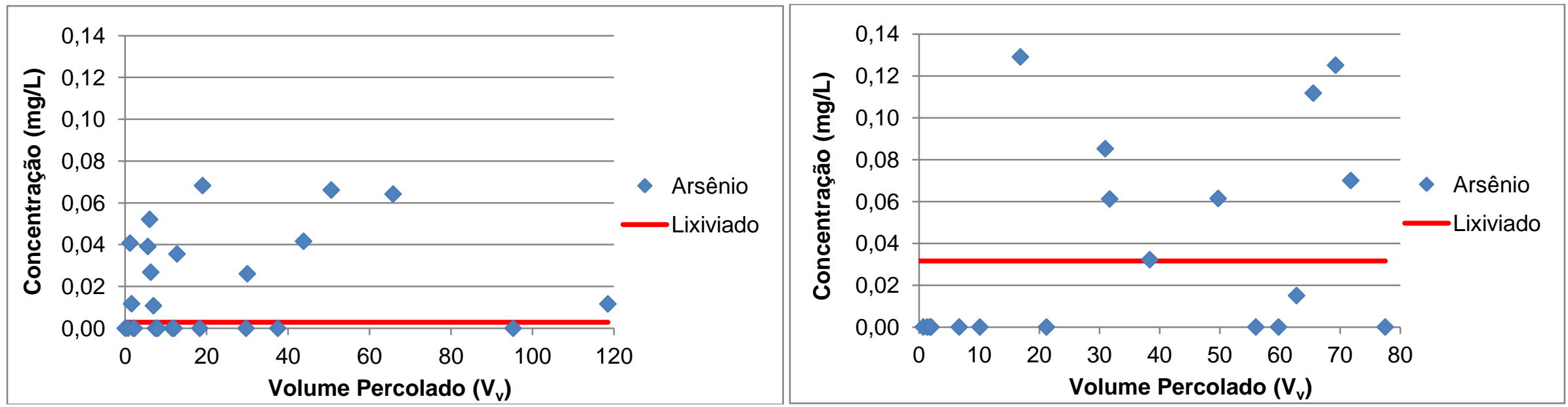

(a)

(b)

Figura 5-15 - Concentrações do elemento arsênio durante os ensaios de coluna nos corpos-de-prova: (a) CP 05 ; (b) CP 06.

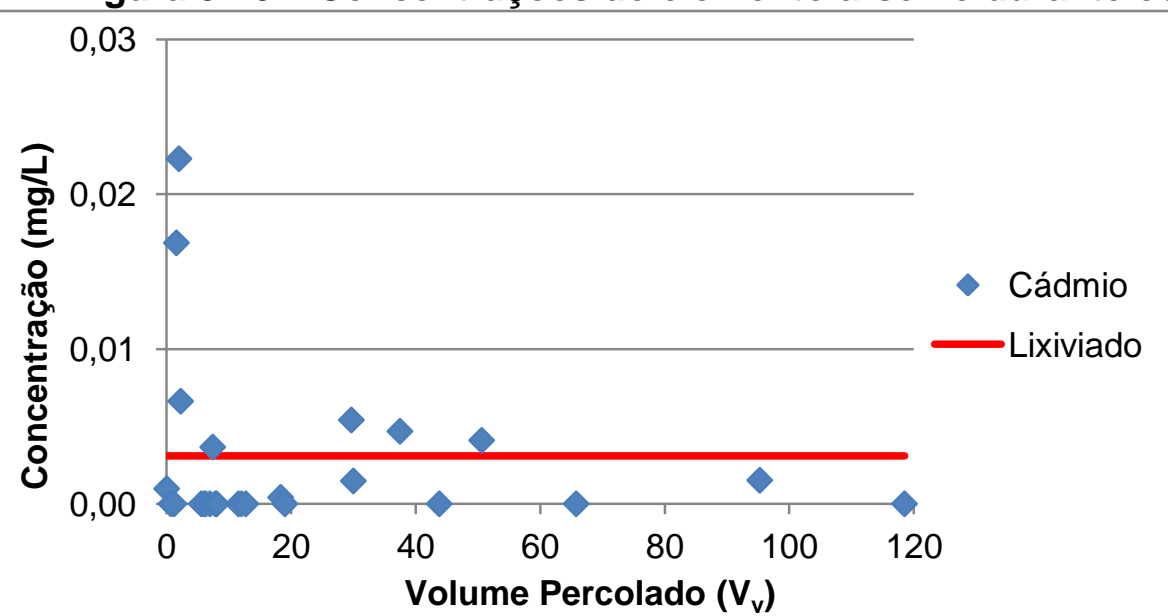

(a)

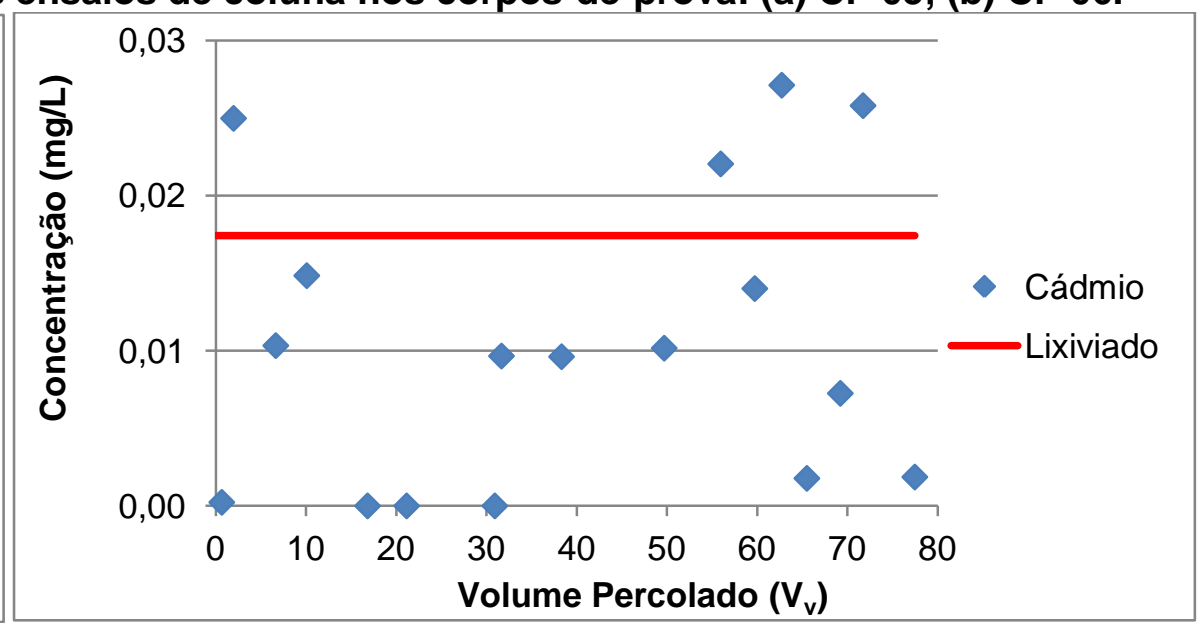

Figura 5-16 - Concentrações do elemento cádmio durante os ensaios de coluna nos corpos-de-prova: (a) CP 05 ; (b) CP 06. 


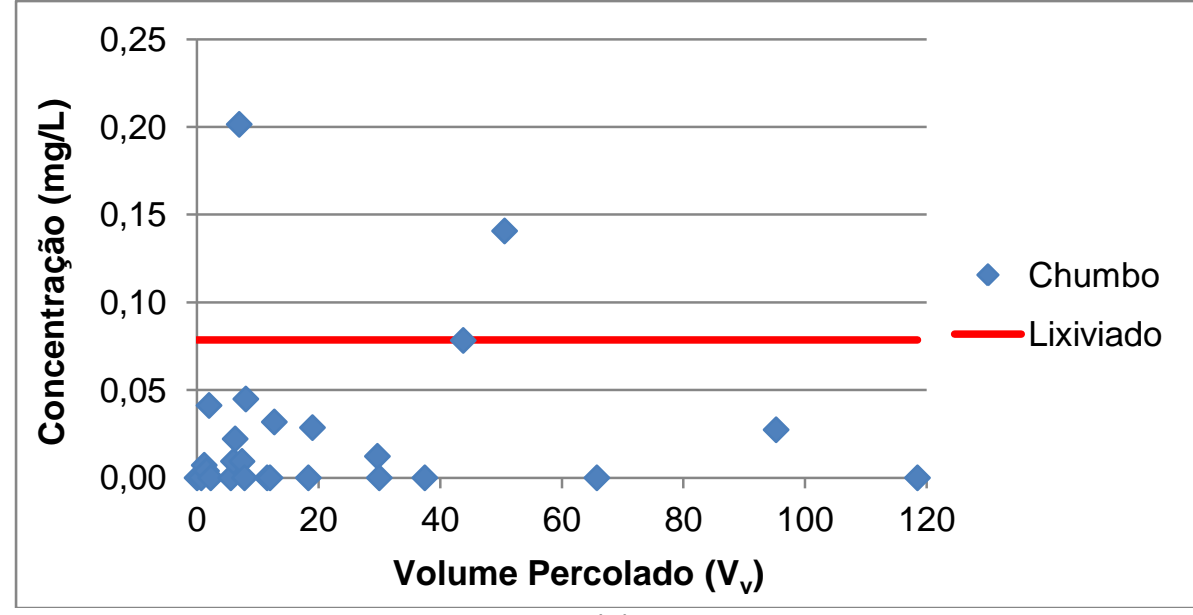

(a)

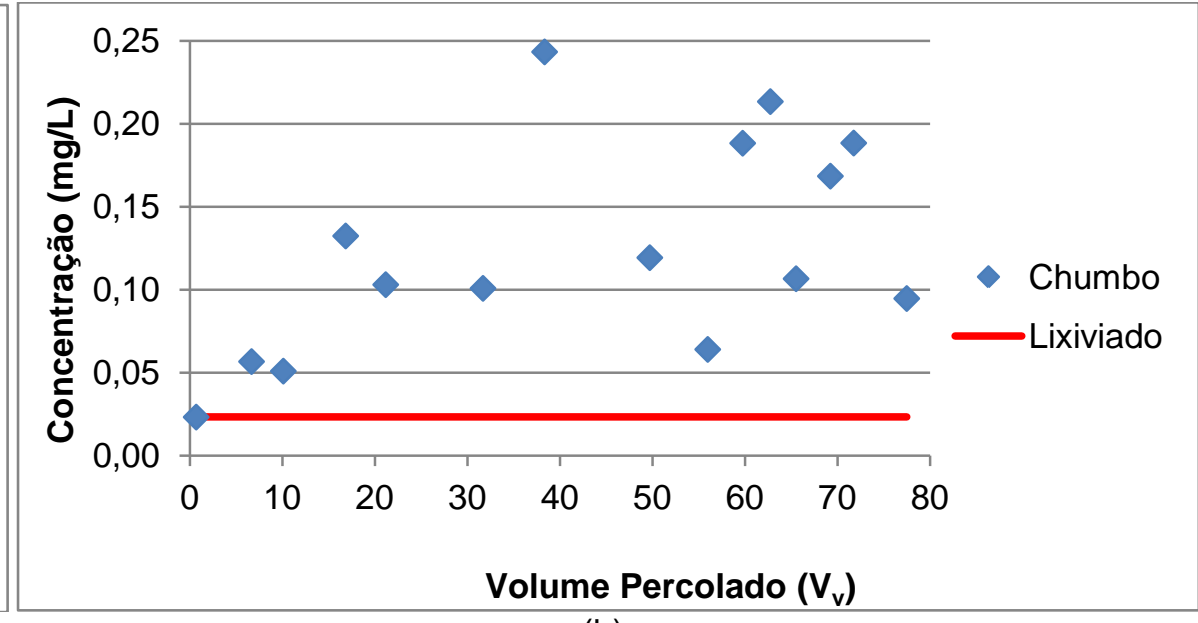

(b)

Figura 5-17 - Concentrações do elemento chumbo durante os ensaios de coluna nos corpos-de-prova: (a) CP 05 ; (b) CP 06.

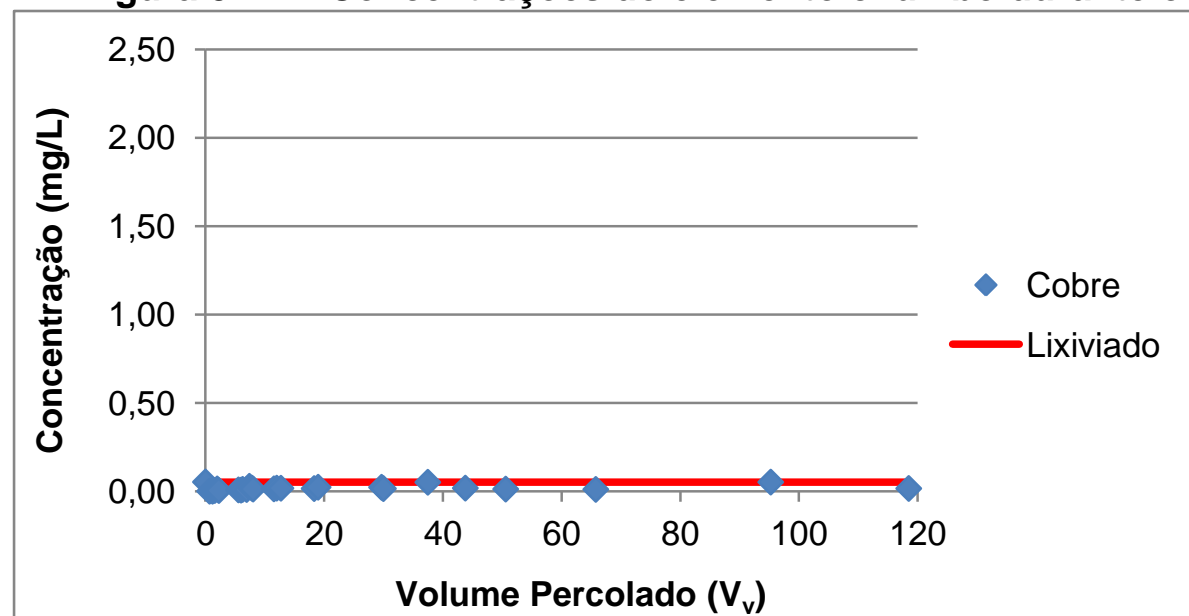

(a)

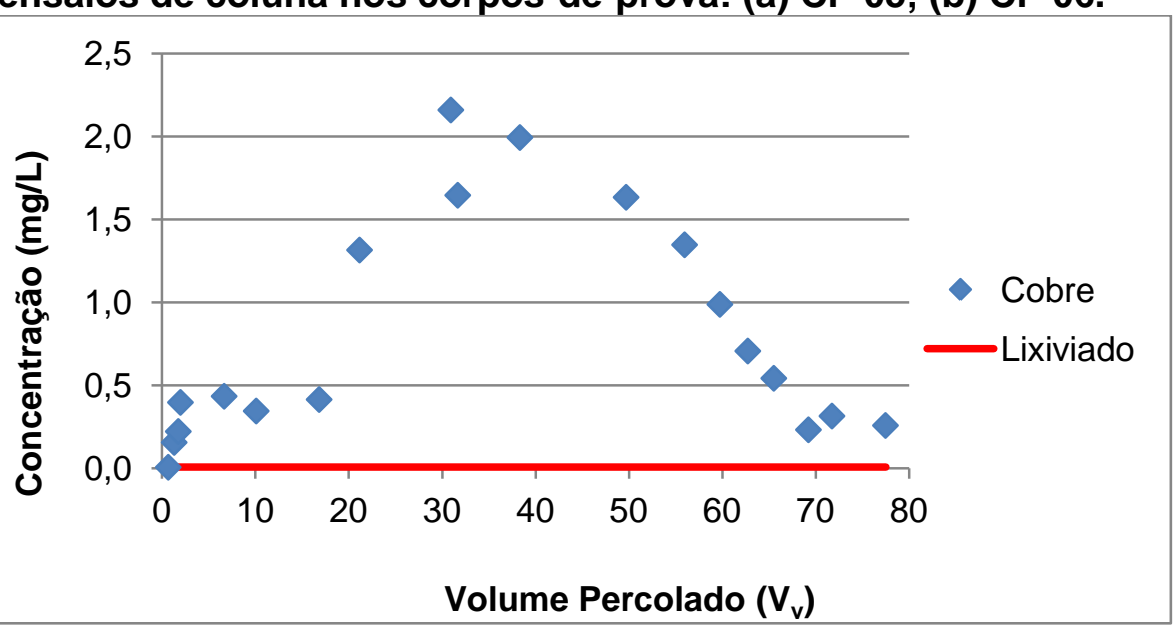

(b)

Figura 5-18 - Concentrações do elemento cobre durante os ensaios de coluna nos corpos-de-prova: (a) CP 05 ; (b) CP 06. 


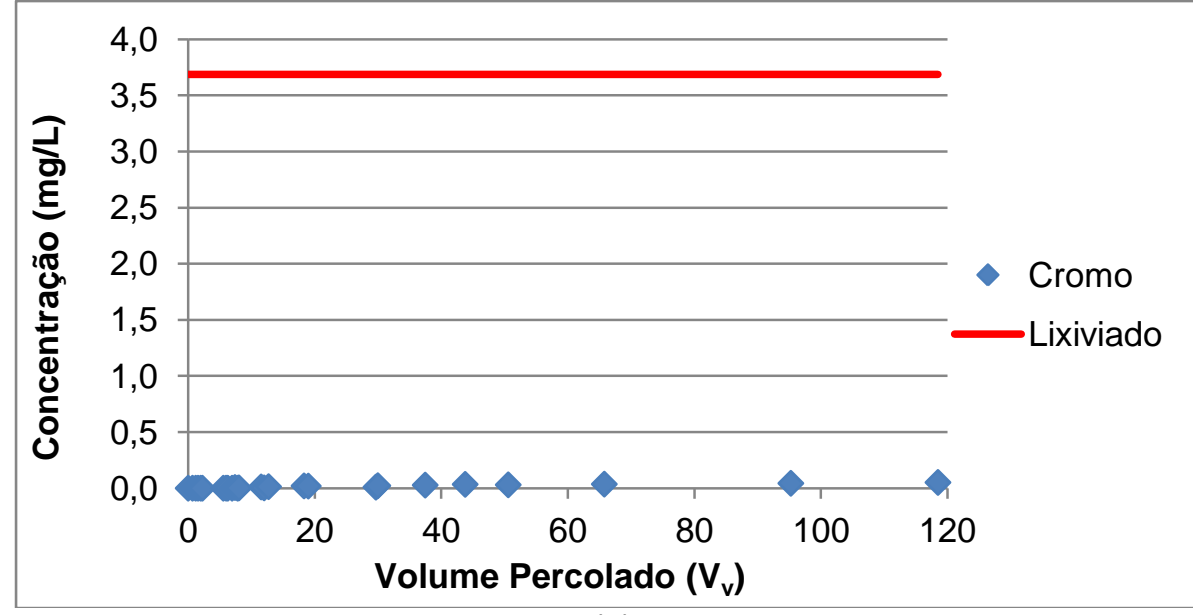

(a)

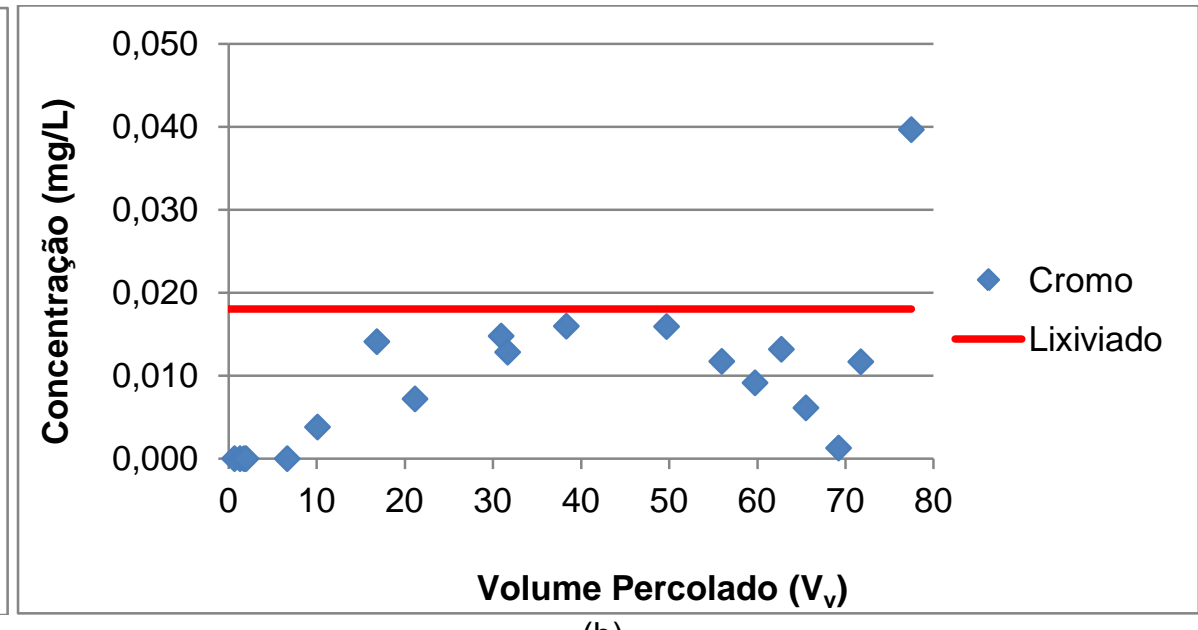

(b)

Figura 5-19 - Concentrações do elemento cromo durante os ensaios de coluna nos corpos-de-prova: (a) CP 05 ; (b) CP 06.

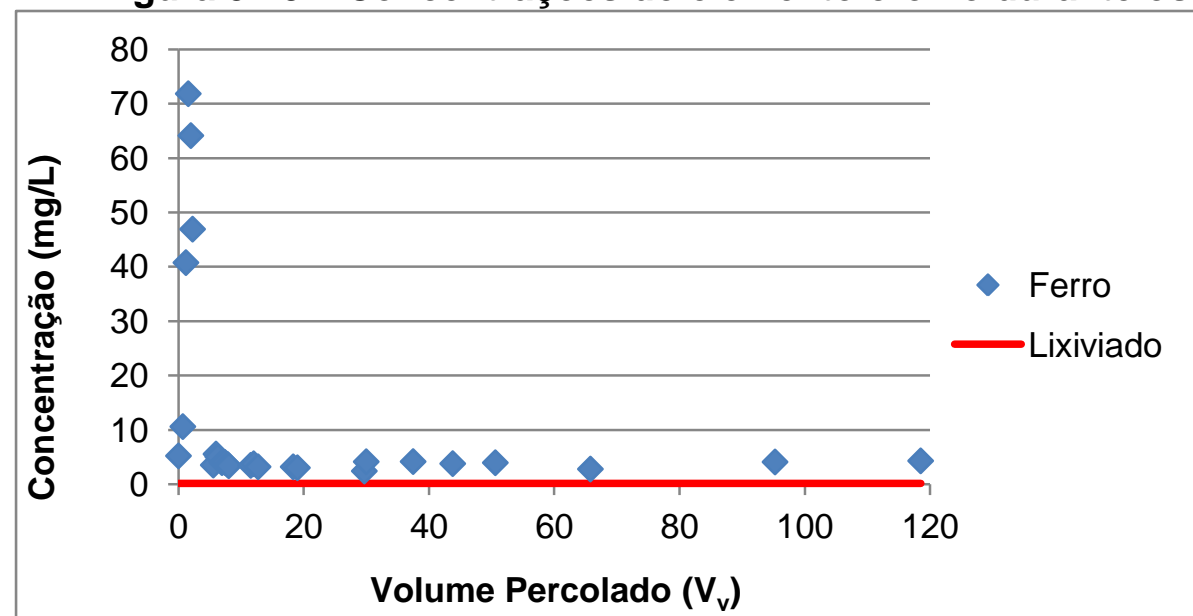

(a)

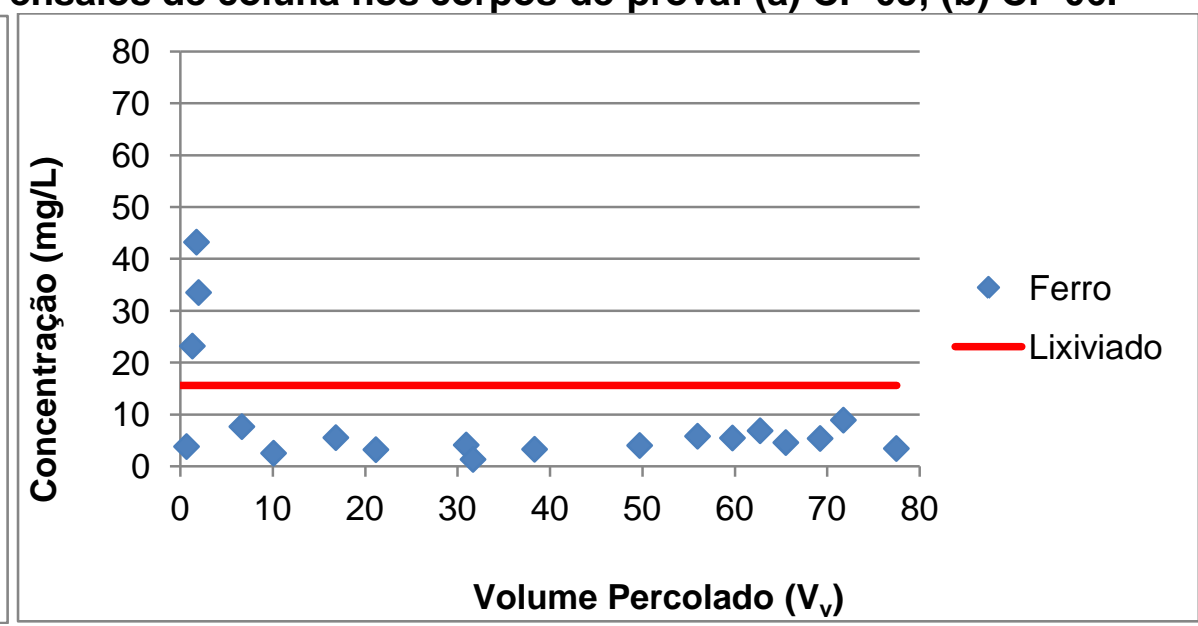

(b)

Figura 5-20 - Concentrações do elemento ferro durante os ensaios de coluna nos corpos-de-prova: (a) CP 05 ; (b) CP 06. 


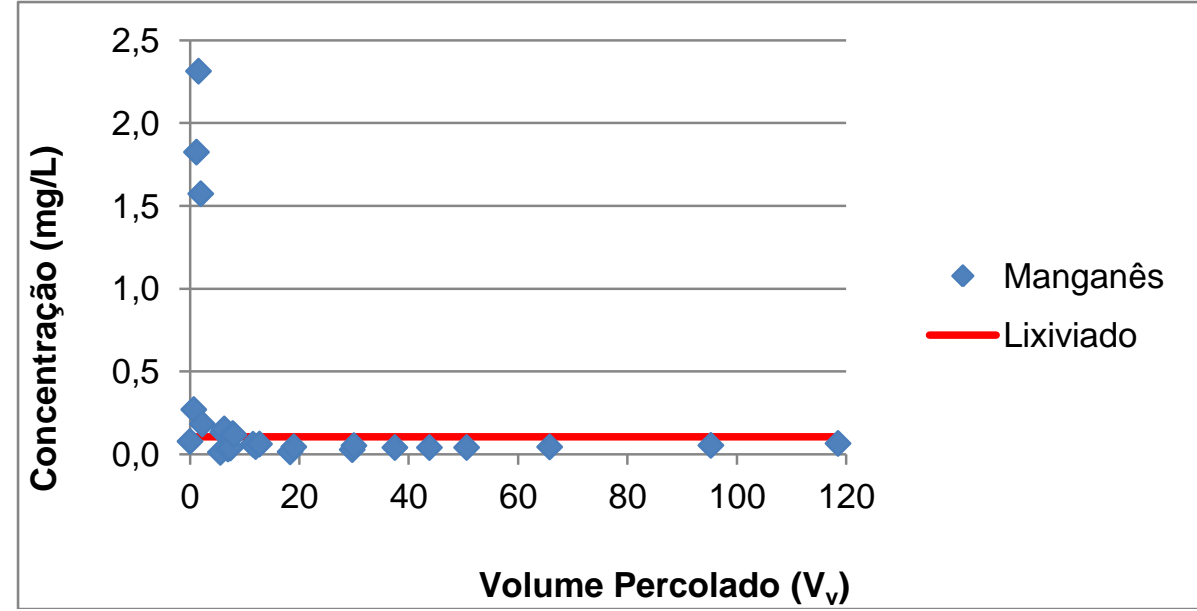

(a)

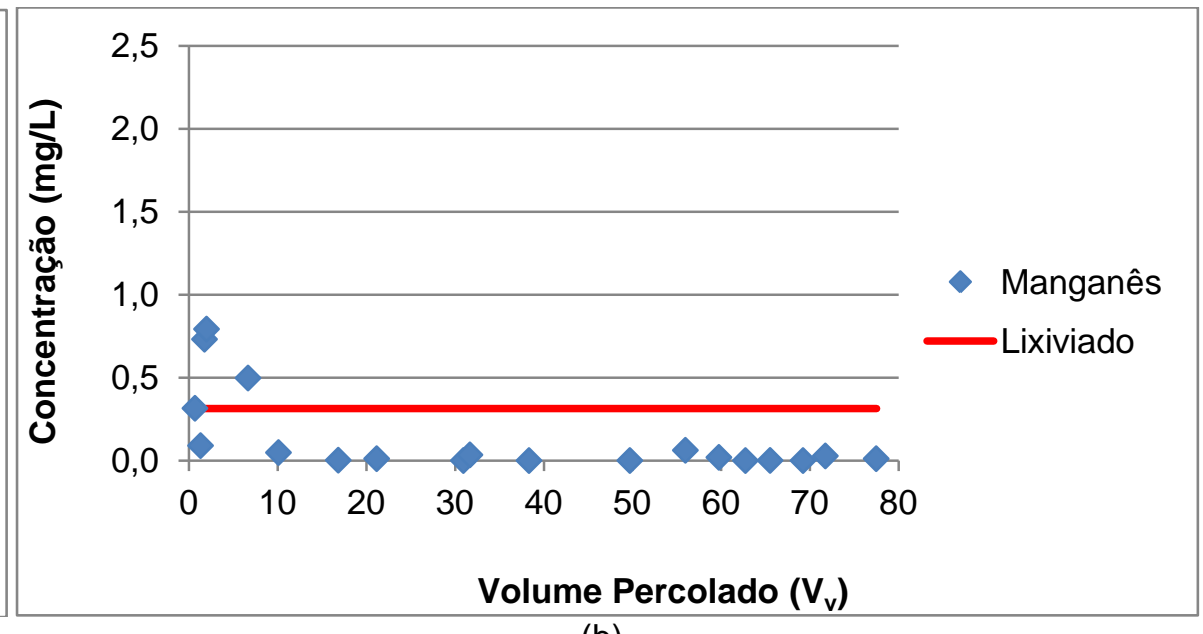

(b)

Figura 5-21 - Concentrações do elemento manganês durante os ensaios de coluna nos corpos-de-prova: (a) CP 05 ; (b) CP 06.

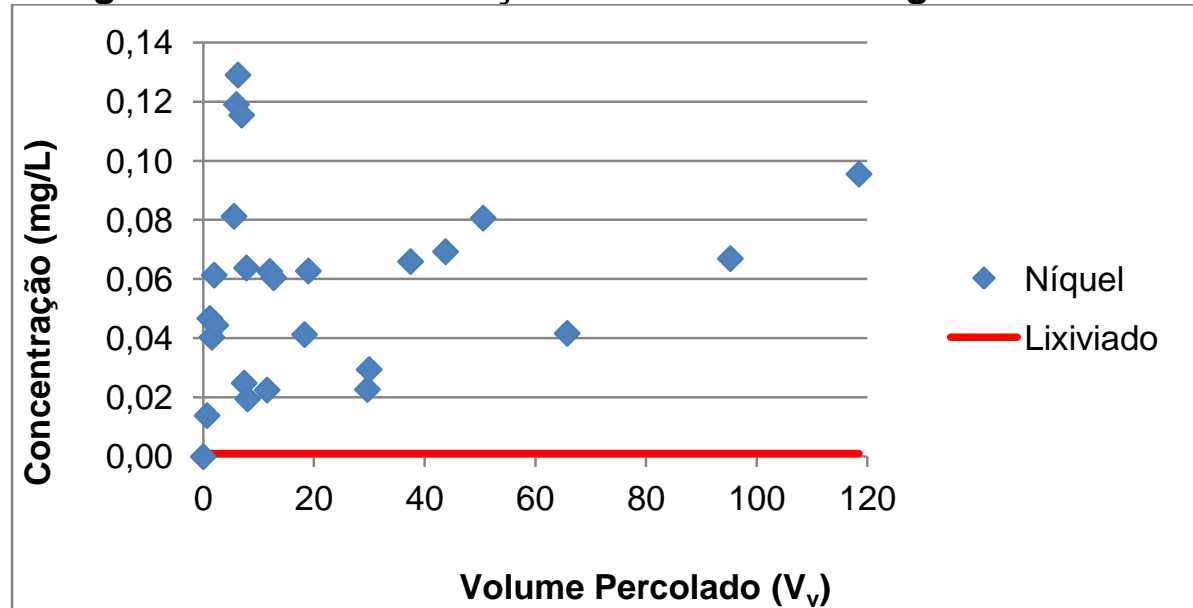

(a)

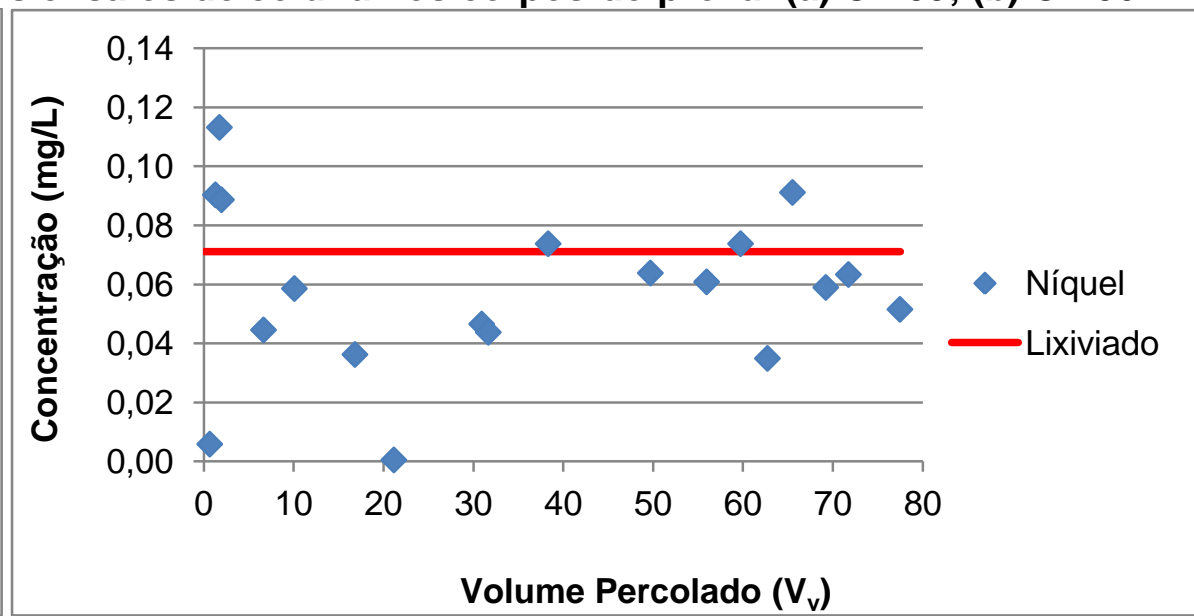

(b)

Figura 5-22 - Concentrações do elemento níquel durante os ensaios de coluna nos corpos-de-prova: (a) CP 05 ; (b) CP 06. 


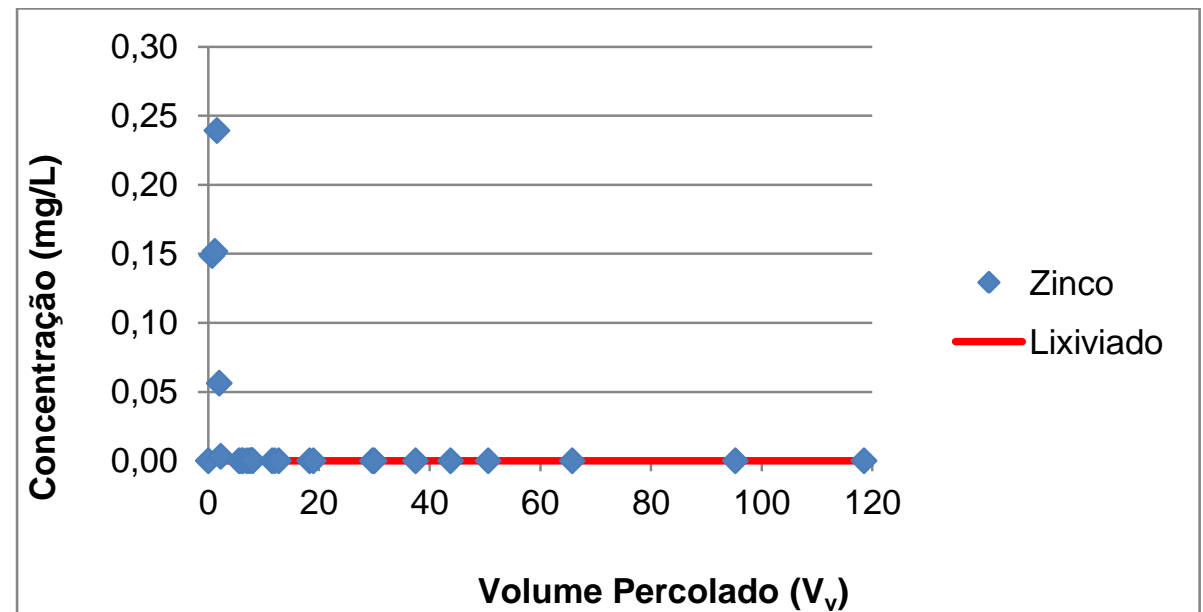

(a)

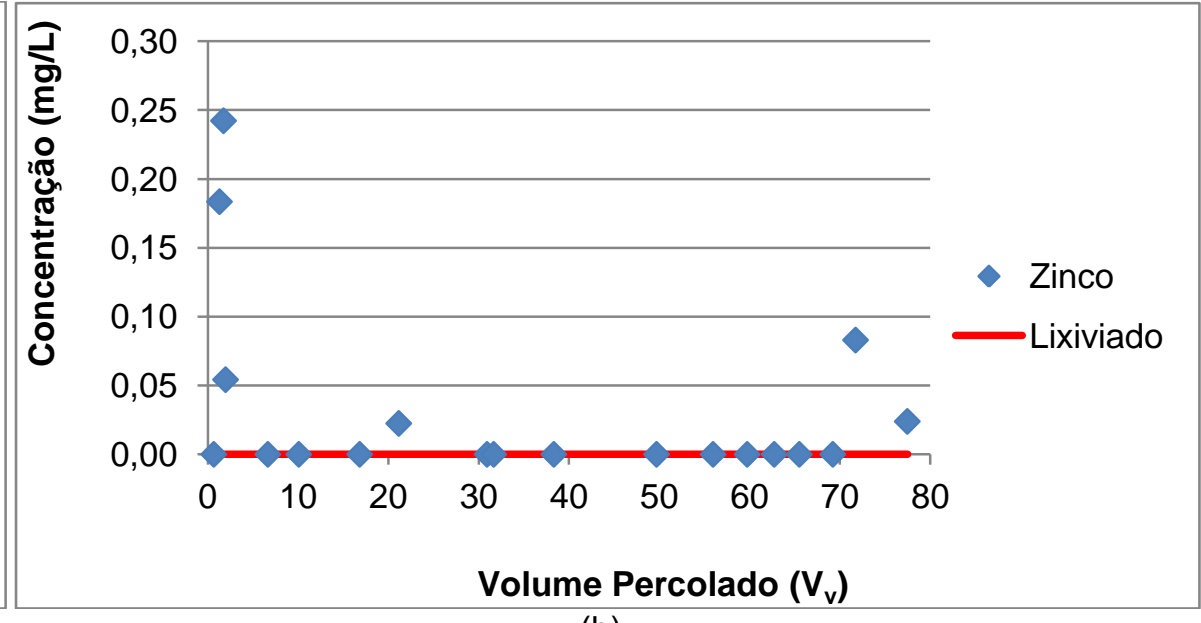

(b)

Figura 5-23 - Concentrações do elemento zinco durante os ensaios de coluna nos corpos-de-prova: (a) CP 05 ; (b) CP 06. 
Observa-se grande dispersão de resultados nos corpos-de-prova CP 05 e CP 06, para os elementos arsênio, cádmio, chumbo e níquel.

Com exceção do cromo nos dois corpos-de-prova e do cobre no CP 05, foram observadas concentrações efluentes superiores à concentração afluente.

Para o ferro, manganês e zinco, a concentração máxima (pico) ocorreu para um volume percolado de lixiviado de, aproximadamente, 2 volumes de vazios. A partir deste volume percolado, as concentrações desses elementos diminuíram drasticamente, mantendo-se próximas ou inferiores às concentrações correspondentes no lixiviado. Possivelmente o lixiviado mobilizou o ferro, o manganês e o zinco presentes naturalmente no solo devido à diferença de $\mathrm{pH}$ e carga iônica em relação à água dos poros, ou seja, tais elementos foram liberados pelo solo.

Para o cádmio no CP 05, julgou-se ocorrer um comportamento semelhante ao observado para o ferro, manganês e zinco. Porém, os resultados para o cádmio com - CP 06 apresentaram grande dispersão de resultados, não sendo possível confirmar esta hipótese.

Pela análise química por fluorescência de raios $X$, constatou-se a presença de chumbo, cobre, cromo, ferro, níquel, manganês e zinco no solo natural. Por outro lado, metais adsorvidos e não constituintes dos grãos minerais podem não ser detectados por esta técnica analítica semiquantitativa. Assim, não se pode descartar a ocorrência de cádmio e arsênio adsorvidos naturalmente no solo.

As concentrações de cromo nas amostras efluentes não superaram as concentrações afluentes durante a duração dos ensaios. O cobre apresentou comportamento muito diferente nos dois ensaios: no ensaio com o CP 05, as concentrações efluentes não superaram a concentração no lixiviado, enquanto no ensaio com o CP 06 ocorreu um pico de concentração após a passagem de cerca de 30 volumes de vazios de lixiviado, com um valor muito superior à concentração no lixiviado.

As concentrações afluentes acima da concentração de partida (do lixiviado) podem ser explicadas pela dessorção ou solubilização de metais presentes nos grãos do 
solo. Enquanto alguns cátions foram retidos, outros foram dessorvidos ou dissolvidos. Este comportamento foi observado para uma argila laterítica residual de diabásio de Campinas/SP para os metais alumínio e ferro (dissolvidos), cádmio, cálcio, chumbo, cromo magnésio, potássio e sódio, entre outros (dessorvidos) (TSUGAWA et al., 2002; TSUGAWA, 2004; BOSCOV, 2010).

As concentrações dos elementos analisados nas amostras efluentes não seguem o comportamento clássico de ensaios de coluna, nos quais as concentrações crescem do valor nulo até a concentração na solução afluente. A composição do lixiviado de aterro sanitário, com presença de muitos elementos em concentrações distintas, pode explicar o comportamento complexo observado nestes ensaios de coluna: os elementos presentes competem entre si pelos sítios de adsorção, sendo adsorvidos e causando a dessorção e a dissolução de elementos presentes naturalmente no solo. Portanto, não foi possível calcular $D_{d h}$ e $R_{d}$ para os ensaios em questão.

A ampla bibliografia de parâmetros de transporte de metais em solos geralmente baseia-se em ensaios com soluções sintéticas. Mesmo que muitas investigações tenham utilizado soluções multimetálicas, ainda assim outros constituintes são frequentemente encontrados em elevada concentração nos lixiviados reais, por exemplo, sólidos solúveis e suspensos, nitrogênio em diversas fases, carbono orgânicos, ânions, entre outros, tornando muito mais difícil a interpretação dos resultados.

Ademais, a aplicação de gradiente baixo, situação mais representativa de configurações operacionais de aterros sanitários, acarretou na colmatação dos poros do solo (corpo-de-prova CP 03). A utilização de gradiente elevado, evitando a colmatação, não representa adequadamente a situação de campo, como já vem sendo discutido no meio técnico. Cria-se assim um impasse para a obtenção de parâmetros representativos de transporte de poluentes de lixiviado real de aterro sanitário em solo por meio de ensaios de coluna.

Nesta pesquisa tomaram-se medidas para minimizar possíveis erros experimentais: limpeza dos equipamentos utilizados (vidrarias, espátulas, balões volumétricos, frascos de digestão etc.), concentração do ácido nítrico, utilização de água com elevado grau de pureza (água milli-Q), qualidade da solução multielementar para calibração do ICP-AES, minimizou-se a quantidade avolumada para diminuir erros 
por diluição, cuidado para evitar perda de material por filtração na transferência (seringas para acoplamento da membrana), substituição da filtração com seringa por filtro de membrana. Mesmo assim, houve grande dispersão de resultados, o que dificultou a análise, mas não muda a dificuldade de interpretar os resultados.

\subsection{Análise da contaminação de campo por metais}

As concentrações dos elementos arsênio, cádmio, chumbo, cobre, cromo, ferro, manganês, níquel e zinco presentes nas amostras - dos perfis coletados no subsolo da lagoa não impermeabilizada, do lodo acumulado no fundo da lagoa e do solo natural não contaminado - constam na Tabela 5-7. Estão apresentados os valores individuais e médios das triplicatas de cada amostra.

A distribuição de concentrações dos elementos chumbo, cobre, cromo, ferro, manganês e zinco ao longo da profundidade para os três perfis amostrados sob a lagoa não impermeabilizada estão apresentados da Figura 5-24 à Figura 5-29. Nas figuras constam também as concentrações no solo natural (background) e no lodo. Todas as concentrações apresentadas nas figuras são os valores médios das triplicatas de cada amostra.

Considerando-se que durante a amostragem foi observada a presença de lodo nos poros do solo até a profundidade de $0,5 \mathrm{~m}$, representaram-se nas figuras as concentrações de elementos no lodo até esta profundidade.

Praticamente todos os valores de concentração obtidos na determinação no equipamento ICP-AES, exceto para o elemento químico ferro e alguns valores do elemento manganês, foram abaixo de $1 \mathrm{mg} / \mathrm{L}$ (1ppm). Foi importante evitar o avolumamento excessivo das soluções originadas a partir da digestão ácida das amostras, situação que poderia conduzir à redução das concentrações a ponto destas atingirem valores abaixo do limite de detecção do equipamento. 
Tabela 5-7 - Concentrações dos elementos químicos nas amostras de solo (mg/Kg).

\begin{tabular}{|c|c|c|c|c|c|c|c|c|c|c|c|c|c|c|c|c|c|c|c|}
\hline & \multirow{3}{*}{ Amostra } & \multicolumn{18}{|c|}{ Elementos Químicos } \\
\hline & & \multicolumn{2}{|c|}{ Arsênio } & \multicolumn{2}{|c|}{ Cádmio } & \multicolumn{2}{|c|}{ Chumbo } & \multicolumn{2}{|c|}{ Cobre } & \multicolumn{2}{|c|}{ Cromo } & \multicolumn{2}{|c|}{ Ferro } & \multicolumn{2}{|c|}{ Manganês } & \multicolumn{2}{|c|}{ Níquel } & \multicolumn{2}{|c|}{ Zinco } \\
\hline & & $\begin{array}{l}\text { em cada } \\
\text { triplicata }\end{array}$ & Média & $\begin{array}{l}\text { em cada } \\
\text { triplicata }\end{array}$ & média & $\begin{array}{l}\text { em cada } \\
\text { triplicata }\end{array}$ & média & $\begin{array}{c}\text { em cada } \\
\text { triplicata }\end{array}$ & média & $\begin{array}{l}\text { em cada } \\
\text { triplicata }\end{array}$ & média & $\begin{array}{l}\text { em cada } \\
\text { triplicata }\end{array}$ & média & $\begin{array}{l}\text { em cada } \\
\text { triplicata }\end{array}$ & média & $\begin{array}{l}\text { em cada } \\
\text { triplicata }\end{array}$ & média & $\begin{array}{l}\text { em cada } \\
\text { triplicata }\end{array}$ & média \\
\hline \multirow{14}{*}{$\begin{array}{c}\text { Perfil } \\
1\end{array}$} & \multirow{2}{*}{$\begin{array}{c}\text { Profundidade } \\
0,25 \mathrm{~m}\end{array}$} & $\begin{array}{l}0,00 \\
0.00\end{array}$ & 0.00 & $\begin{array}{l}0 \\
0\end{array}$ & 0 & $\frac{10,59}{7,21}$ & 8.59 & $\begin{array}{l}7,41 \\
6,57\end{array}$ & 6.81 & $\begin{array}{l}17,08 \\
12,60\end{array}$ & 15,36 & $\begin{array}{l}13.537 \\
16.800\end{array}$ & 14.557 & \begin{tabular}{|l|}
34,08 \\
29,91
\end{tabular} & 31.98 & $\begin{array}{l}0,00 \\
0,00\end{array}$ & 0.00 & $\begin{array}{l}25,56 \\
49,07\end{array}$ & 24.88 \\
\hline & & 0,00 & & 0 & & 7,99 & & 6,44 & & 16,39 & & 13.334 & & 31,95 & & 0,00 & & 0,00 & \\
\hline & & 0,00 & & 0 & & 6,62 & & 6,25 & & 16,47 & & 13.788 & & 30,73 & & 0,00 & & 0,00 & \\
\hline & $\begin{array}{l}\text { Profundidade } \\
0.50 \mathrm{~m}\end{array}$ & 0,00 & 0,00 & 0 & 0 & 6,78 & 6,53 & 6,44 & 6,40 & 16,70 & 16,39 & 13.986 & 13.809 & 30,46 & 29,92 & 0,00 & 0,00 & 0,00 & 0,00 \\
\hline & & 0,00 & & 0 & & 6,18 & & 6,50 & & 15,99 & & 13.655 & & 28,58 & & 0,00 & & 0,00 & \\
\hline & & 0,00 & & 0 & & 7,14 & & 8,64 & & 17,18 & & 14.693 & & 35,75 & & 0,00 & & 0,00 & \\
\hline & Profundidade & 0,00 & 0,00 & 0 & 0 & 11,06 & 8,97 & 8,52 & 8,27 & 20,47 & 18,65 & 16.022 & 14.913 & 41,12 & 37,89 & 0,00 & 0,00 & 9,51 & 0,00 \\
\hline & & 0,00 & & 0 & & 8,71 & & 7,64 & & 18,30 & & 14.024 & & 36,81 & & 0,00 & & 0,00 & \\
\hline & & 0,00 & & 0 & & 10,41 & & 7,81 & & 22,04 & & 15.253 & & 34,36 & & 0,00 & & 0,00 & \\
\hline & Profundidade & 0,00 & 0,00 & 0 & 0 & 6,83 & 7,62 & 8,67 & 9,17 & 24,77 & 24,14 & 16.794 & 14.825 & 40,13 & 37,59 & 0,00 & 0,41 & 0,00 & 0,00 \\
\hline & & 0,00 & & 0 & & 5,61 & & 11,04 & & 25,63 & & 12.430 & & 38,28 & & 1,23 & & 12,38 & \\
\hline & & 0,00 & & 0 & & 6,57 & & 6,94 & & 14,92 & & 11.373 & & 40,13 & & 0,00 & & 2,08 & \\
\hline & Profundidade & 0,00 & 0,33 & 0 & 0 & 7,81 & 6,84 & 7,05 & 7,52 & 15,31 & 16,53 & 11.672 & 12.177 & 40,68 & 43,75 & 0,00 & 0,00 & 3,48 & 2,67 \\
\hline & & 1,00 & & 0 & & 6,13 & & 8,57 & & 19,36 & & 13.487 & & 50,45 & & 0,00 & & 2,44 & \\
\hline & & 0,00 & & 0 & & 7,16 & & 7,88 & & 19,37 & & 15.185 & & 32,13 & & 0,00 & & 0,00 & \\
\hline & Profundidade & 0,00 & 0,00 & 0 & 0 & 10,07 & 7,07 & 6,29 & 6,54 & 18,58 & 17,71 & 14.098 & 13.821 & 29,14 & 28,70 & 0,00 & 0,00 & 0,00 & 0,00 \\
\hline & & 0,00 & & 0 & & 3,98 & & 5,46 & & 15,17 & & 12.181 & & 24,82 & & 0,00 & & 0,00 & \\
\hline & & 0,00 & & 0 & & 5,36 & & 5,60 & & 16,38 & & 13.218 & & 54,54 & & 0,00 & & 0,00 & \\
\hline & Profundidade & 0,00 & 0,00 & 0 & 0 & 7,30 & 6,48 & 5,46 & 5,93 & 16,00 & 17,36 & 12.838 & 13.709 & 55,15 & 57,34 & 0,00 & 0,00 & 0,00 & 0,00 \\
\hline & & 0,00 & & 0 & & 6,78 & & 6,74 & & 19,69 & & 15.071 & & 62,33 & & 0,00 & & 0,00 & \\
\hline & & 0,00 & & 0 & & 7,10 & & 8,01 & & 22,86 & & 17.126 & & 43,02 & & 0,00 & & 0,00 & \\
\hline $\begin{array}{l}\text { Perfil } \\
2\end{array}$ & Profundidade & 0,00 & 0,00 & 0 & 0 & 6,20 & 7,28 & 8,08 & 7,90 & 23,92 & 23,42 & 17.481 & 17.183 & 43,71 & 43,05 & 0,00 & 0,00 & 0,00 & 0,00 \\
\hline & & 0,00 & & 0 & & 8,55 & & 7,62 & & 23,49 & & 16.940 & & 42,43 & & 0,00 & & 0,00 & \\
\hline & & 0,00 & & 0 & & 10,67 & & 9,78 & & 30,58 & & 19.926 & & 50,62 & & 0,00 & & 0,00 & \\
\hline & Profundidade & 0,00 & 0,00 & 0 & 0 & 11,57 & 10,12 & 8,69 & 9,43 & 29,05 & 30,11 & 19.777 & 19.866 & 48,69 & 50,28 & 0,00 & 0,00 & 0,00 & 0,00 \\
\hline & & 0,00 & & 0 & & 8,13 & & 9,82 & & 30,70 & & 19.895 & & 51,53 & & 0,00 & & 0,00 & \\
\hline & & 0,00 & & 0 & & 5,96 & & 7,76 & & 17,18 & & 14.826 & & 40,69 & & 0,00 & & 0,00 & \\
\hline & Profundidade & 0,00 & 0,00 & 0 & 0 & 10,43 & 7,29 & 10,05 & 8,85 & 22,81 & 20,21 & 16.871 & 16.010 & 50,19 & 45,94 & 0,00 & 0,00 & 2,82 & 0,00 \\
\hline & & 0,00 & & 0 & & 5,48 & & 8,73 & & 20,64 & & 16.332 & & 46,95 & & 0,00 & & 0,00 & \\
\hline & & 0,00 & & 0 & & 30,47 & & 54,49 & & 56,30 & & 41.361 & & 295,98 & & 5,59 & & 73,81 & \\
\hline & Profundidade & 0,00 & 0,87 & 0 & 0 & 26,13 & 26,49 & 52,28 & 48,96 & 55,13 & 52,76 & 39.873 & 39.859 & 288,43 & 278,83 & 1,85 & 2,48 & 62,91 & 48,63 \\
\hline & & 2,61 & & 0 & & 22,86 & & 40,11 & & 46,86 & & 38.343 & & 252,07 & & 0,00 & & 9,16 & \\
\hline & & 0,00 & & 0 & & 10,31 & & 8,71 & & 21,74 & & 16.841 & & 54,41 & & 0,00 & & 0,00 & \\
\hline & Profundidade & 0,00 & 0,00 & 0 & 0 & 7,70 & 7,82 & 8,55 & 8,32 & 19,68 & 19,74 & 15.887 & 15.857 & 49,74 & 50,33 & 0,00 & 0,00 & 0,00 & 0,00 \\
\hline & 0,50 m & 0,00 & & 0 & & 5,46 & & 7,71 & & 17,81 & & 14.844 & & 46,83 & & 0,00 & & 18,68 & \\
\hline & & 0,00 & & 0 & & 3,29 & & 7,43 & & 22,12 & & 14.737 & & 41,43 & & 0,00 & & 0,00 & \\
\hline Pertil & Profundidade & 0,00 & 0,00 & 0 & 0 & 5,86 & 5,14 & 6,18 & 7,25 & 18,87 & 20,87 & 13.944 & 14.603 & 38,63 & 41,46 & 0,00 & 0,00 & 0,00 & 0,00 \\
\hline & & 0,00 & & 0 & & 6,28 & & 8,13 & & 21,63 & & 15.128 & & 44,31 & & 0,00 & & 56,30 & \\
\hline & & 0,00 & & 0 & & 5,24 & & 8,31 & & 22,48 & & 13.443 & & 20,74 & & 0,00 & & 0,00 & \\
\hline & Profundidade & 0,00 & 0,00 & 0 & 0 & 7,45 & 6,30 & 8,91 & 9,27 & 24,85 & 25,03 & 13.924 & 14.211 & 21,51 & 22,77 & 0,00 & 0,00 & 0,00 & 0,00 \\
\hline & & 0,00 & & 0 & & 6,20 & & 10,58 & & 27,77 & & 15.266 & & 26,08 & & 0,00 & & 0,00 & \\
\hline & & 0,00 & & 0 & & 5,08 & & 7,11 & & 14,79 & & 14.402 & & 36,83 & & 0,00 & & 0,00 & \\
\hline & Profundidade & 0,00 & 0,00 & 0 & 0 & 6,91 & 6,92 & 9,63 & 8,79 & 17,90 & 16,96 & 15.439 & 15.061 & 42,81 & 41,25 & 0,00 & 0,00 & 0,00 & 0,00 \\
\hline & & 0,00 & & 0 & & 8,76 & & 9,65 & & 18,18 & & 15.342 & & 44,13 & & 0,00 & & 6,29 & \\
\hline & & 0,00 & & 0 & & 1,95 & & 2,48 & & 4,55 & & 5.956 & & 1,07 & & 0,00 & & 0,00 & \\
\hline & Solo Natural & 0,00 & 0,00 & 0 & 0 & 5,10 & 2,35 & 4,33 & 3,31 & 21,49 & 11,96 & 15.214 & 9.982 & 16,16 & 7,59 & 0,00 & 0,00 & 0,00 & 0,00 \\
\hline & & 0,00 & & 0 & & 0,00 & & 3,12 & & 9,86 & & 8.775 & & 5,54 & & 0,00 & & 0,00 & \\
\hline & & 0,00 & & 0 & & 28,96 & & 77,49 & & 45,20 & & 28.320 & & 250,85 & & 13,17 & & 72,46 & \\
\hline & Lodo Seco & 8,82 & 2,94 & 0 & 0 & 25,93 & 26,30 & 81,69 & 77,72 & 48,74 & 43,90 & 28.918 & 26.940 & 257,86 & 244,46 & 12,41 & 12,27 & 77,51 & 72,60 \\
\hline & & 0,00 & & 0 & & 24,01 & & 73,98 & & 37,77 & & 23.581 & & 224,68 & & 11,22 & & 67,82 & \\
\hline
\end{tabular}




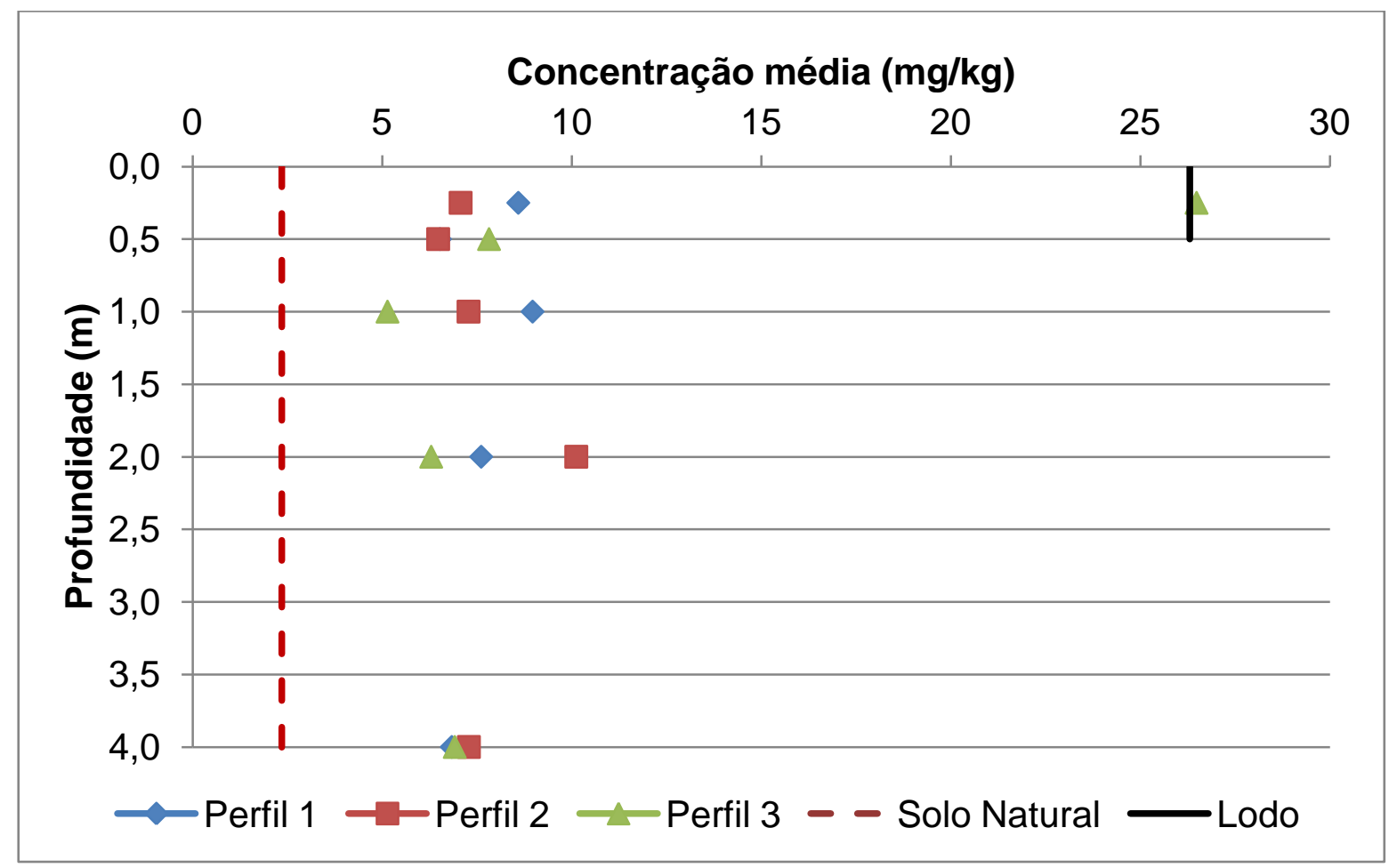

Figura 5-24 - Perfis de contaminação do chumbo no subsolo da lagoa não impermeabilizada.

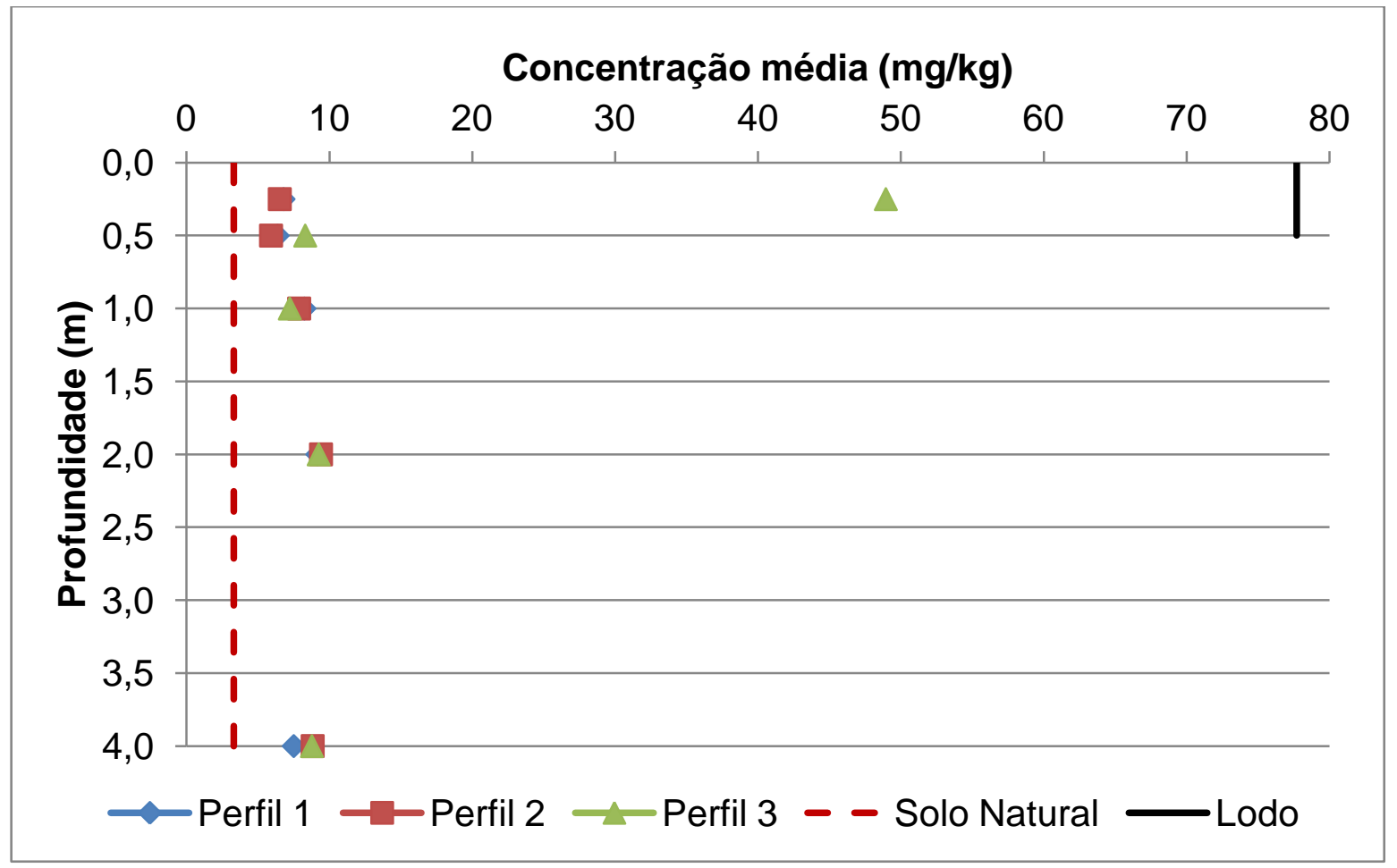

Figura 5-25 - Perfis de contaminação do cobre no subsolo da lagoa não impermeabilizada. 


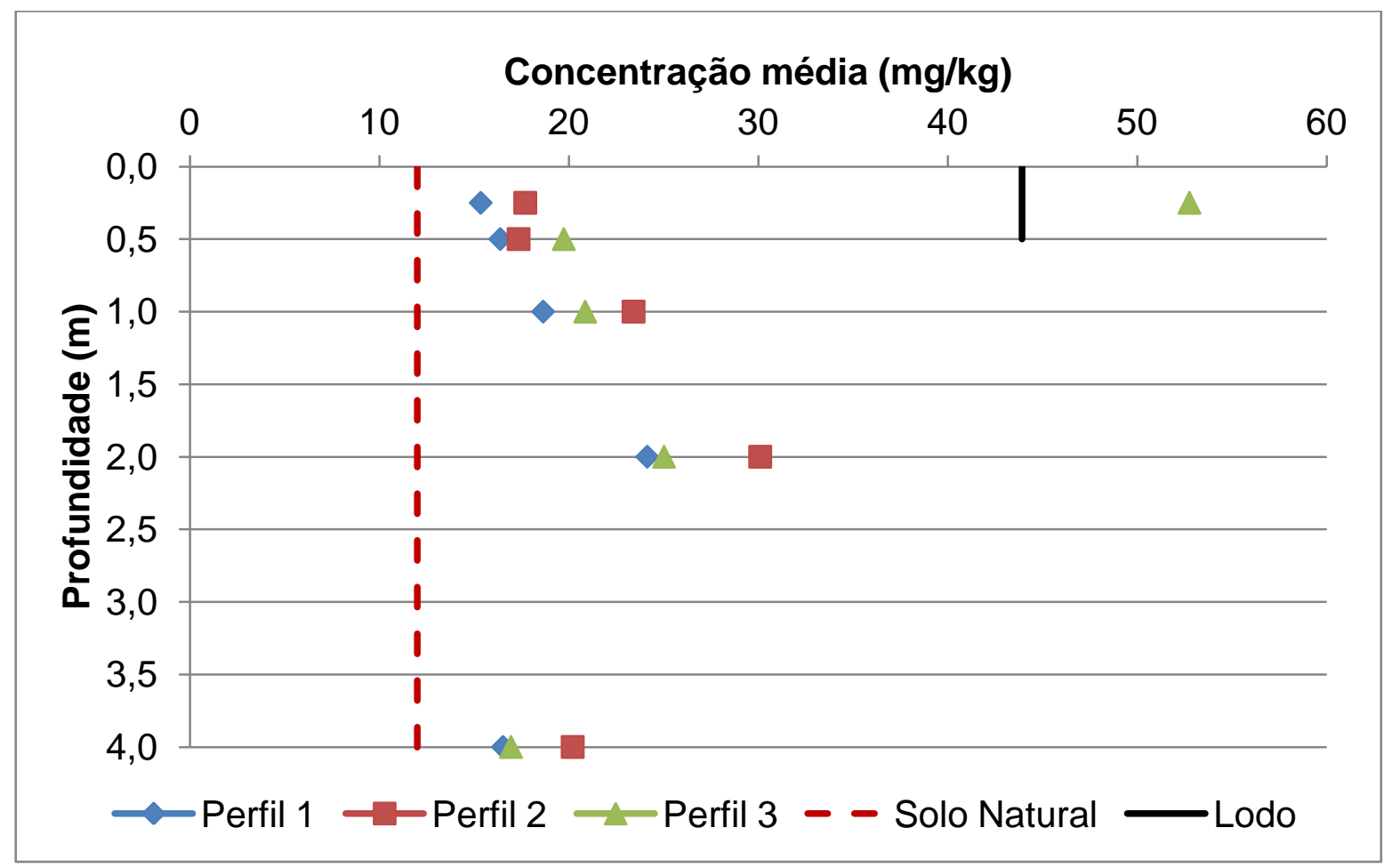

Figura 5-26 - Perfis de contaminação do cromo no subsolo da lagoa não impermeabilizada.

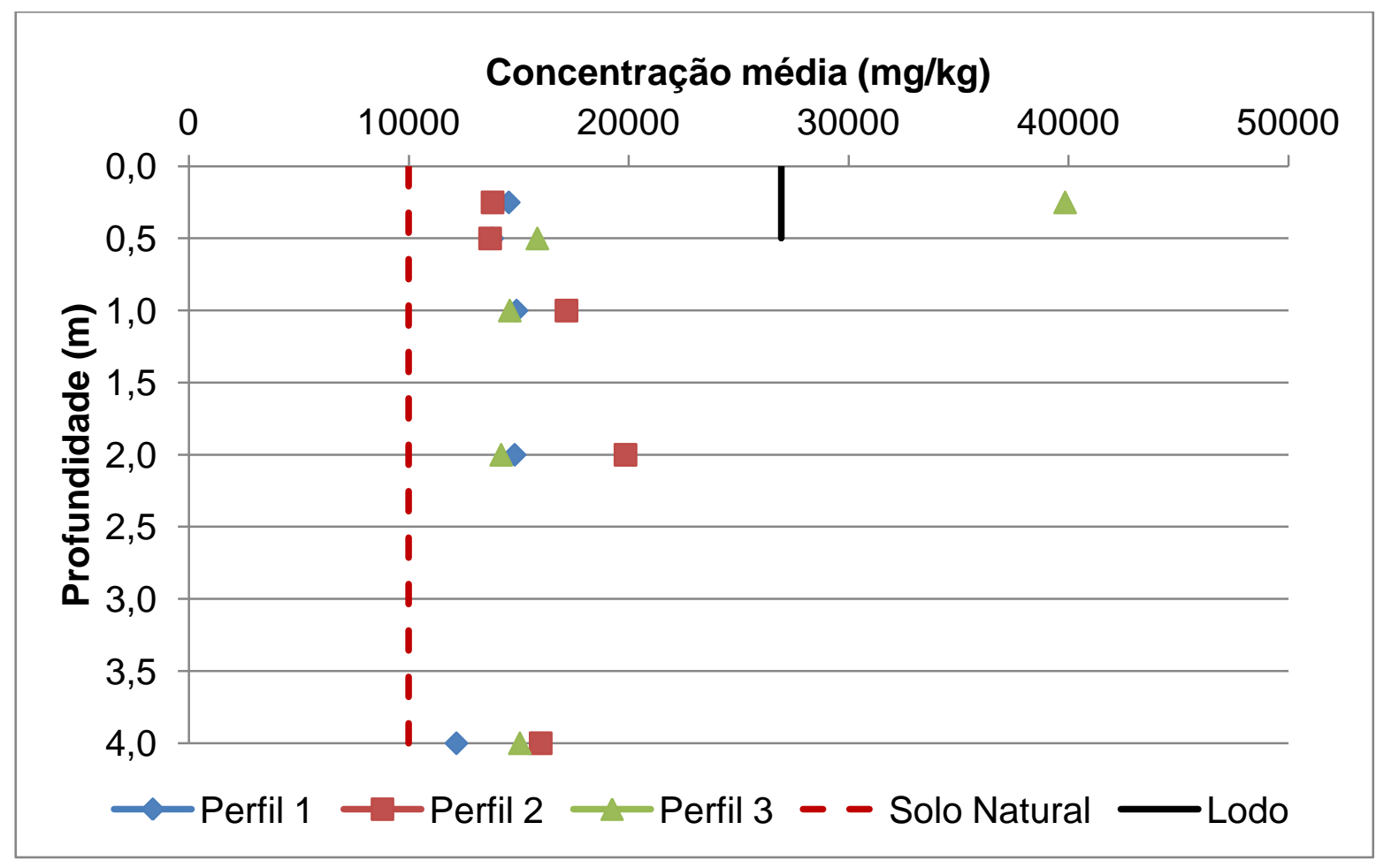

Figura 5-27 - Perfis de contaminação do ferro no subsolo da lagoa não impermeabilizada. 


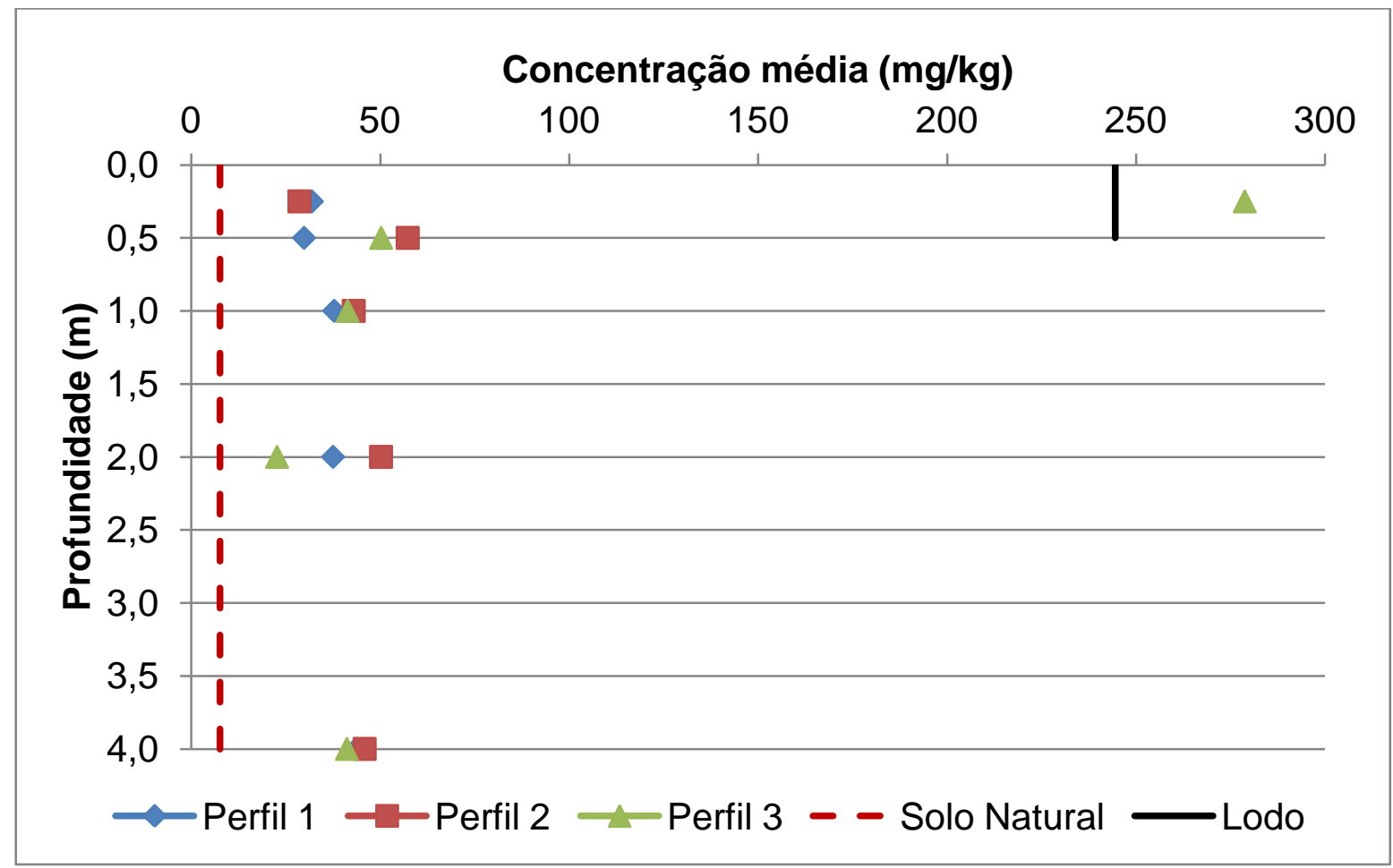

Figura 5-28 - Perfis de contaminação do manganês no subsolo da lagoa não impermeabilizada.

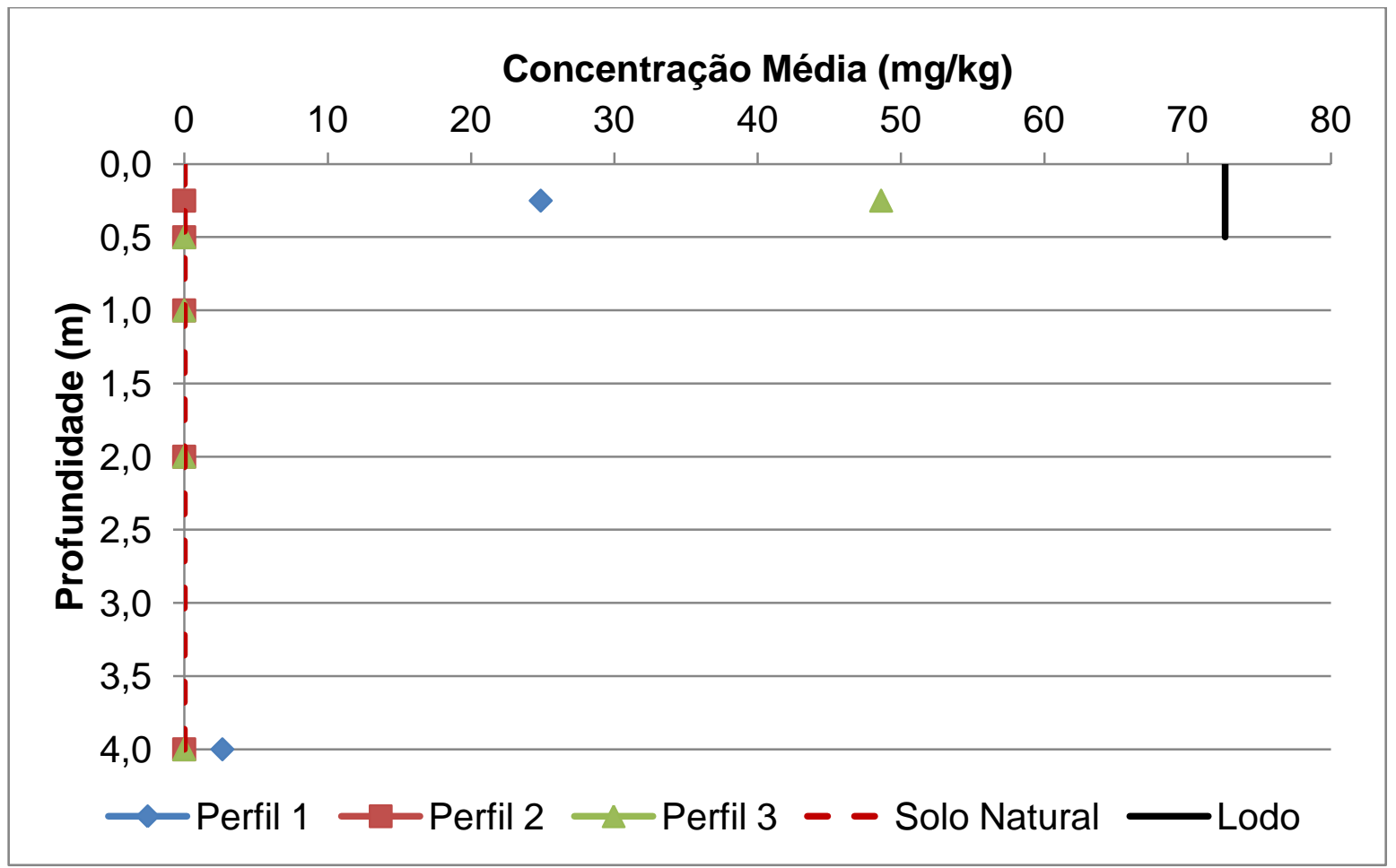

Figura 5-29 - Perfis de contaminação do zinco no subsolo da lagoa não impermeabilizada. 
Foram encontradas cinco situações relacionadas aos elementos químicos estudados:

- o elemento cádmio não foi detectado no solo natural, no lodo e nos perfis;

- os elementos arsênio e níquel não foram detectados no solo natural nem nos perfis, mas foram detectados no lodo;

- o elemento zinco não foi detectado no solo natural, mas foi detectado no lodo e nos perfis;

- os elementos chumbo, cobre e manganês foram detectados no solo natural (background), no lodo e em todas as amostras dos perfis;

- o elemento ferro também foi detectado no solo natural (background), no lodo e em todas as amostras dos perfis, porém em concentrações muito superiores às dos demais elementos, até três ordens de grandeza mais elevadas do que as dos outros elementos determinados e das soluções utilizadas para a calibração do espectrômetro.

Cabe observar que concentrações não nulas foram obtidas para o arsênio (dois valores em 45 determinações), o cádmio (três valores em 45 determinações) e o zinco (seis valores em 45 determinações), em valores únicos de poucas triplicatas. Esses valores não foram considerados no cálculo da média das triplicatas.

Um poço de monitoramento, localizado a cerca de $80 \mathrm{~m}$ a jusante da lagoa de acumulação de lixiviado, com nível de água à profundidade de $6 \mathrm{~m}$, não detectou quaisquer dos elementos em maio de 2011 (com exceção de $0,75 \mathrm{mg} / \mathrm{L}$ de manganês) e em março de 2013. Os limites de detecção das leituras foram de: $0,001 \mathrm{mg} / \mathrm{L}$ para arsênio, $0,001 \mathrm{mg} / \mathrm{L}$ para cádmio, $0,01 \mathrm{mg} / \mathrm{L}$ para chumbo, 0,009 mg/L para cobre, $0,01 \mathrm{mg} / \mathrm{L}$ para cromo, $0,03 \mathrm{mg} / \mathrm{L}$ para ferro, $0,01 \mathrm{mg} / \mathrm{L}$ para manganês, $0,01 \mathrm{mg} / \mathrm{L}$ para níquel e $0,1 \mathrm{mg} / \mathrm{L}$ para zinco.

Observa-se que todas as determinações de chumbo, cobre, cromo, ferro, manganês e zinco relativas à profundidade de $0,25 \mathrm{~m}$ no perfil 3 foram significativamente superiores comparadas às demais. Tais valores destoantes podem ter ocorrido por contaminação das amostras durante os procedimentos laboratoriais; ou mesmo podem ser valores compatíveis com a contaminação real de campo, explicados por uma eventual ocorrência de maior porcentagem de finos local ou de um caminho preferencial de contaminação neste perfil. 
Excetuando-se a profundidade de $0,25 \mathrm{~m}$ no perfil 3, as concentrações dos elementos no solo ao longo dos perfis são muito inferiores às do lodo. Não se observa uma frente de contaminação teórica: com base em ensaios laboratoriais e na bibliografia, esperava-se um perfil de concentrações com valores decrescentes em função do aumento da profundidade.

Para todos os elementos, percebe-se um aumento das concentrações nas camadas intermediárias em relação às mais rasas, situação também observada em Ferrari et al. (2010), ressaltando-se que os solos estudados em ambas as pesquisas pertencem ao mesmo grupo geológico e são arenosos. A Tabela 5-8 apresenta uma comparação dos valores obtidos nas duas pesquisas: arsênio e cádmio não foram detectados no lodo e no solo; as concentrações dos demais elementos estão na mesma ordem de grandeza, tanto no lodo quanto no solo, com exceção do valor máximo de cobre detectado no solo contaminado por Ferrari et al. (2010) .

Tabela 5-8 - Concentrações obtidas em Ferrari et al. (2010) e nas amostras estudas nesta pesquisa.

\begin{tabular}{|c|c|c|c|c|c|c|}
\hline \multirow{3}{*}{ Elemento } & \multicolumn{3}{|c|}{ Ferrari et al. (2010) } & \multicolumn{3}{|c|}{$\begin{array}{c}\text { Amostras do aterro sanitário de } \\
\text { Botucatu/SP }\end{array}$} \\
\hline & \multicolumn{2}{|c|}{$\begin{array}{c}\text { Concentração no } \\
\text { solo contaminado } \\
(\mathrm{mg} / \mathrm{kg})\end{array}$} & \multirow{2}{*}{$\begin{array}{c}\text { Concentração } \\
\text { no lodo } \\
(\mathrm{mg} / \mathrm{Kg})\end{array}$} & \multicolumn{2}{|c|}{$\begin{array}{c}\text { Concentração no } \\
\text { solo contaminado } \\
(\mathrm{mg} / \mathrm{kg})\end{array}$} & \multirow{2}{*}{$\begin{array}{c}\text { Concentração } \\
\text { no lodo } \\
(\mathrm{mg} / \mathrm{Kg})\end{array}$} \\
\hline & Mínima & Máxima & & Mínima & Máxima & \\
\hline Arsênio & n.d. & n.d. & n.d. & n.d. & n.d. & n.d. \\
\hline Cádmio & n.d. & n.d. & n.d. & n.d. & n.d. & n.d. \\
\hline Chumbo & 2,9 & 4,0 & 14 & 5,14 & 10,1 & 26,3 \\
\hline Cobre & 5,6 & 76 & 31 & 5,93 & 9,43 & 77,7 \\
\hline Cromo & 4,8 & 8,6 & 32 & 15,4 & 30,1 & 43,9 \\
\hline Ferro & 8.200 & 72.300 & 31.700 & 12.177 & 19.866 & 26.940 \\
\hline Manganês & 43 & 277 & 249 & 22,8 & 57,3 & 244 \\
\hline Níquel & 1,3 & 5,9 & 10 & 0 & 0 & 12,3 \\
\hline Zinco & 2,2 & 20 & 59 & 0 & 24,9 & 72,6 \\
\hline
\end{tabular}

As concentrações dos elementos arsênio, cádmio, chumbo, cobre, cromo, níquel e zinco no solo natural (não contaminado ou background) estão significativamente abaixo dos valores de referência de qualidade para solo do estado de São Paulo (CETESB, 2005) apresentados na Tabela 5-9. Para os mesmos elementos as concentrações determinadas nas amostras contaminadas estudadas estão abaixo dos valores de prevenção e intervenção para solo do estado de São Paulo 
(CETESB, 2005) e os valores estabelecidos nacionalmente (CONAMA, 2009). Os elementos ferro e manganês não possuem valores orientadores, pois são elementos que compõem naturalmente os solos brasileiros e, em geral, são encontrados em elevadas concentrações.

Tabela 5-9 - Valores orientadores para solos do estado de São Paulo (CETESB, 2005) e do Brasil (CONAMA, 2009).

\begin{tabular}{|c|c|c|c|c|c|c|}
\hline & \multicolumn{3}{|c|}{ CETESB (2005) } & \multicolumn{3}{c|}{ CONAMA (2009) } \\
\cline { 2 - 7 } & $\begin{array}{c}\text { Valor de } \\
\text { Eleferência } \\
\text { de } \\
\text { Qualidade } \\
(\mathrm{mg} / \mathrm{kg})\end{array}$ & $\begin{array}{c}\text { Valor de } \\
\text { Prevenção } \\
(\mathrm{mg} / \mathrm{kg})\end{array}$ & $\begin{array}{c}\text { Valor de } \\
\text { Intervenção } \\
(\mathrm{mg} / \mathrm{kg})\end{array}$ & $\begin{array}{c}\text { Valor de } \\
\text { Referência } \\
\text { de } \\
\text { Qualidade } \\
(\mathrm{mg} / \mathrm{kg})\end{array}$ & $\begin{array}{c}\text { Valor de } \\
\text { Prevenção } \\
(\mathrm{mg} / \mathrm{kg})\end{array}$ & $\begin{array}{c}\text { Valor de } \\
\text { Intervenção } \\
(\mathrm{mg} / \mathrm{kg})\end{array}$ \\
\hline Arsênio & 3,5 & 15 & 35 & $\mathrm{E}$ & 15 & 35 \\
\hline Cádmio & $<0,5$ & 1,3 & 3 & $\mathrm{E}$ & 1,3 & 3 \\
\hline Chumbo & 17 & 72 & 180 & $\mathrm{E}$ & 72 & 180 \\
\hline Cobre & 35 & 60 & 200 & $\mathrm{E}$ & 60 & 200 \\
\hline Cromo & 40 & 75 & 150 & $\mathrm{E}$ & 75 & 150 \\
\hline Níquel & 13 & 30 & 70 & $\mathrm{E}$ & 30 & 70 \\
\hline Zinco & 60 & 300 & 450 & $\mathrm{E}$ & 300 & 450 \\
\hline
\end{tabular}

Pode-se concluir que, mesmo tendo ocorrido transporte de poluentes da lagoa de lixiviado para o subsolo, com aumento de concentrações em relação ao background do solo, não pode se considerar que o solo esteja contaminado pelos elementos investigados.

É interessante observar que, para os elementos detectados, as concentrações no lixiviado eram da ordem de ppb (partes por bilhão), exceto para cromo na amostra coletada em janeiro de 2013 e para ferro na amostra coletada em março de 2013 , que se apresentaram em ppm (partes por milhão). No lodo, as concentrações dos elementos detectados estavam na ordem de ppm, exceto para o ferro, cujas concentrações atingiram partes por milhares. É possível que o lodo depositado no fundo da lagoa funcione, ao mesmo tempo, como adsorvente dos constituintes do lixiviado (sorvedouro) e como fonte concentrada de poluentes que podem ser mobilizados para o subsolo. 


\subsection{Análise da contaminação de campo por Cloreto, Carbono Orgânico Total e Nitrogênio Kjeldahl Total}

As concentrações de cloreto, carbono orgânico total (COT) e nitrogênio Kjeldahl total (NKT) presentes nas amostras - dos perfis coletados no subsolo da lagoa não impermeabilizada, do lodo acumulado no fundo da lagoa e do solo natural não contaminado - constam na Tabela 5-10. Estão apresentados os valores individuais e médios das triplicatas de cada amostra.

A distribuição de concentrações dos referidos constituintes ao longo da profundidade, para os três perfis amostrados sob a lagoa não impermeabilizada, estão apresentados da Figura 5-30 à Figura 5-32. Da mesma forma que foi apresentada para os metais, nas figuras constam as concentrações no solo natural (background), no lodo e representaram-se as concentrações de elementos no lodo até $0,5 \mathrm{~m}$ de profundidade. As concentrações apresentadas são os valores médios das triplicatas de cada amostra. 
Tabela 5-10 - Concentrações de cloreto, COT e NKT nas amostras de solo (mg/Kg).

\begin{tabular}{|c|c|c|c|c|c|c|c|}
\hline \multicolumn{2}{|c|}{ Amostra } & \multicolumn{2}{|c|}{ Cloreto } & \multicolumn{2}{|c|}{ СOT } & \multicolumn{2}{|c|}{ NKT } \\
\hline \multirow{15}{*}{ Perfil 1} & \multirow{3}{*}{$\begin{array}{c}\text { Profundidade } \\
0,25 \mathrm{~m}\end{array}$} & 389 & \multirow{3}{*}{380} & 891 & \multirow{3}{*}{881} & 15.095 & \multirow{3}{*}{15.100} \\
\hline & & 370 & & 914 & & 15.774 & \\
\hline & & 381 & & 837 & & 14.431 & \\
\hline & \multirow{3}{*}{$\begin{array}{c}\text { Profundidade } \\
0,50 \mathrm{~m}\end{array}$} & 365 & \multirow{3}{*}{372} & 1.224 & \multirow{3}{*}{1.184} & 24.498 & \multirow{3}{*}{24.450} \\
\hline & & 384 & & 1.173 & & 25.581 & \\
\hline & & 368 & & 1.155 & & 23.270 & \\
\hline & \multirow{3}{*}{$\begin{array}{c}\text { Profundidade } \\
1,00 \mathrm{~m}\end{array}$} & 814 & \multirow{3}{*}{813} & 952 & \multirow{3}{*}{928} & 25.140 & \multirow{3}{*}{25.238} \\
\hline & & 821 & & 900 & & 25.581 & \\
\hline & & 803 & & 933 & & 24.992 & \\
\hline & \multirow{3}{*}{$\begin{array}{c}\text { Profundidade } \\
2,00 \mathrm{~m}\end{array}$} & 168 & \multirow{3}{*}{175} & 675 & & 8.726 & \\
\hline & & 184 & & 672 & 672 & 8.630 & 8.843 \\
\hline & & 173 & & 668 & & 9.172 & \\
\hline & & 264 & & 334 & & 37.162 & \\
\hline & rolumaidale & 271 & 272 & 367 & 357 & 37.466 & 37.411 \\
\hline & & 280 & & 371 & & 37.606 & \\
\hline & & 484 & & 1.293 & & 15.118 & \\
\hline & Protundidade & 482 & 480 & 1.105 & 1.238 & 15.517 & 15.195 \\
\hline & & 475 & & 1.315 & & 14.949 & \\
\hline & & 271 & & 948 & & 12.626 & \\
\hline & romunade & 282 & 281 & 1.035 & 993 & 11.160 & 12.062 \\
\hline & & 291 & & 996 & & 12.400 & \\
\hline & & 441 & & 992 & & 21.138 & \\
\hline Perfil 2 & Protundidade & 473 & 462 & 937 & 956 & 20.593 & 20.928 \\
\hline & & 471 & & 939 & & 21.053 & \\
\hline & Profundidade & 373 & & 539 & & 26.178 & \\
\hline & Protunalaade & 391 & 380 & 587 & 580 & 26.514 & 25.527 \\
\hline & & 376 & & 614 & & 23.888 & \\
\hline & & 176 & & 344 & & 18.412 & \\
\hline & Protundidade & 190 & 184 & 296 & 306 & 18.542 & 18.516 \\
\hline & & 186 & & 279 & & 18.593 & \\
\hline & & 877 & & 763 & & 11.709 & \\
\hline & Protundidade & 870 & 876 & 771 & 778 & 12.093 & 11.816 \\
\hline & & 880 & & 801 & & 11.646 & \\
\hline & Profundidade & 783 & & 846 & & 9.151 & \\
\hline & Protundidade & 789 & 786 & 838 & 836 & 9.293 & 9.020 \\
\hline & & 786 & & 823 & & 8.617 & \\
\hline & & 556 & & 951 & & 13.711 & \\
\hline Perfil 3 & Protunalaade & 566 & 564 & 1.109 & 1.009 & 14.316 & 14.577 \\
\hline & & 569 & & 967 & & 15.703 & \\
\hline & & 724 & & 603 & & 15.193 & \\
\hline & rrotunadade & 730 & 730 & 598 & 612 & 16.116 & 15.439 \\
\hline & & 737 & & 636 & & 15.009 & \\
\hline & & 340 & & 634 & & 11.574 & \\
\hline & riumade & 333 & 335 & 591 & 621 & 10.330 & 10.838 \\
\hline & & 332 & & 637 & & 10.611 & \\
\hline & & 134 & & 1.158 & & 5.458 & \\
\hline & Natural & 137 & 136 & 1.079 & 1.118 & 5.318 & 5.409 \\
\hline & & 136 & & 1.118 & & 5.451 & \\
\hline & & 739 & & 5.527 & & 14.916 & \\
\hline & Seco & 744 & 735 & 6.669 & 6.082 & 15.875 & 15.676 \\
\hline & & 723 & & 6.051 & & 16.238 & \\
\hline
\end{tabular}




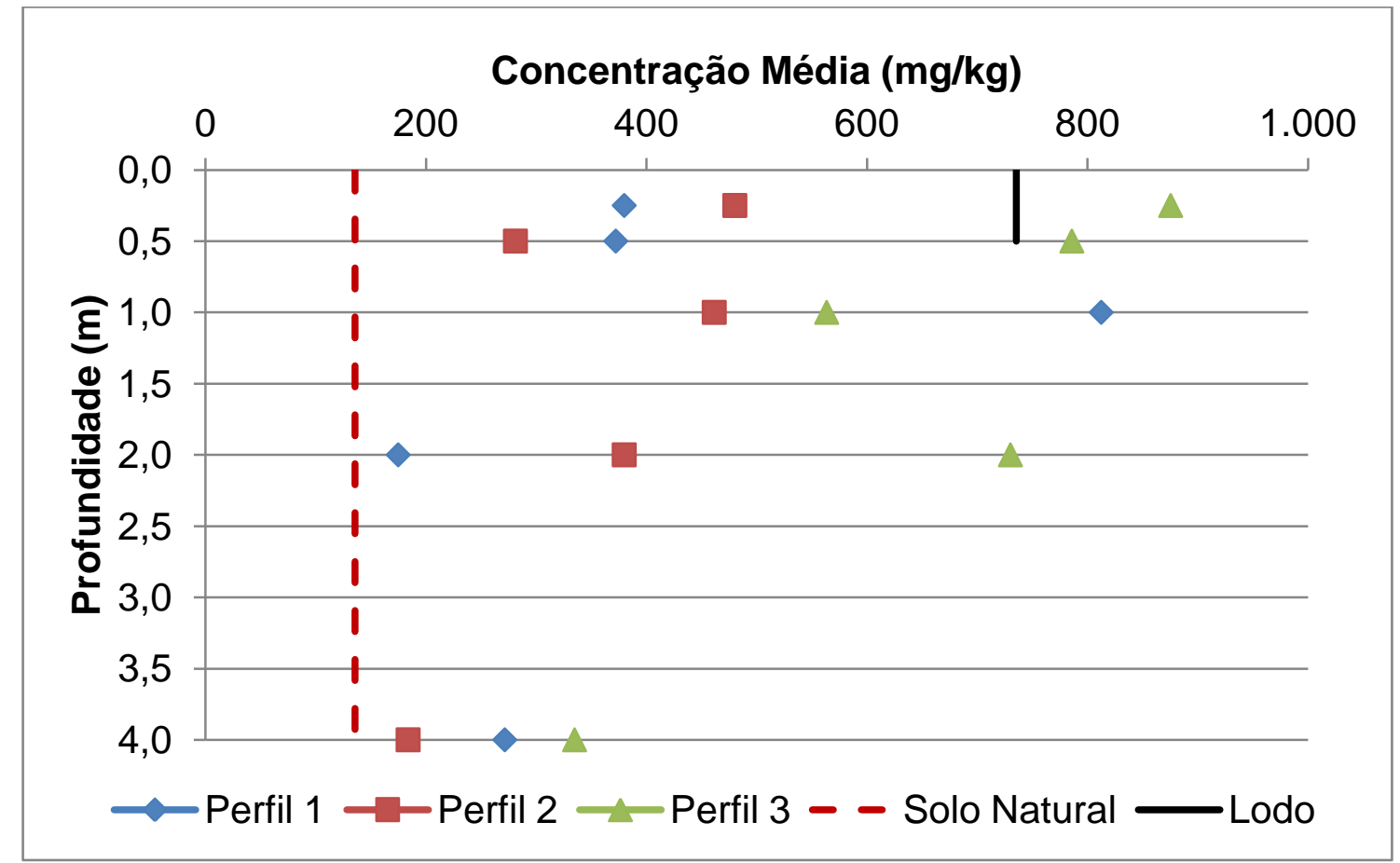

Figura 5-30 - Perfis de contaminação do cloreto no subsolo da lagoa não impermeabilizada.

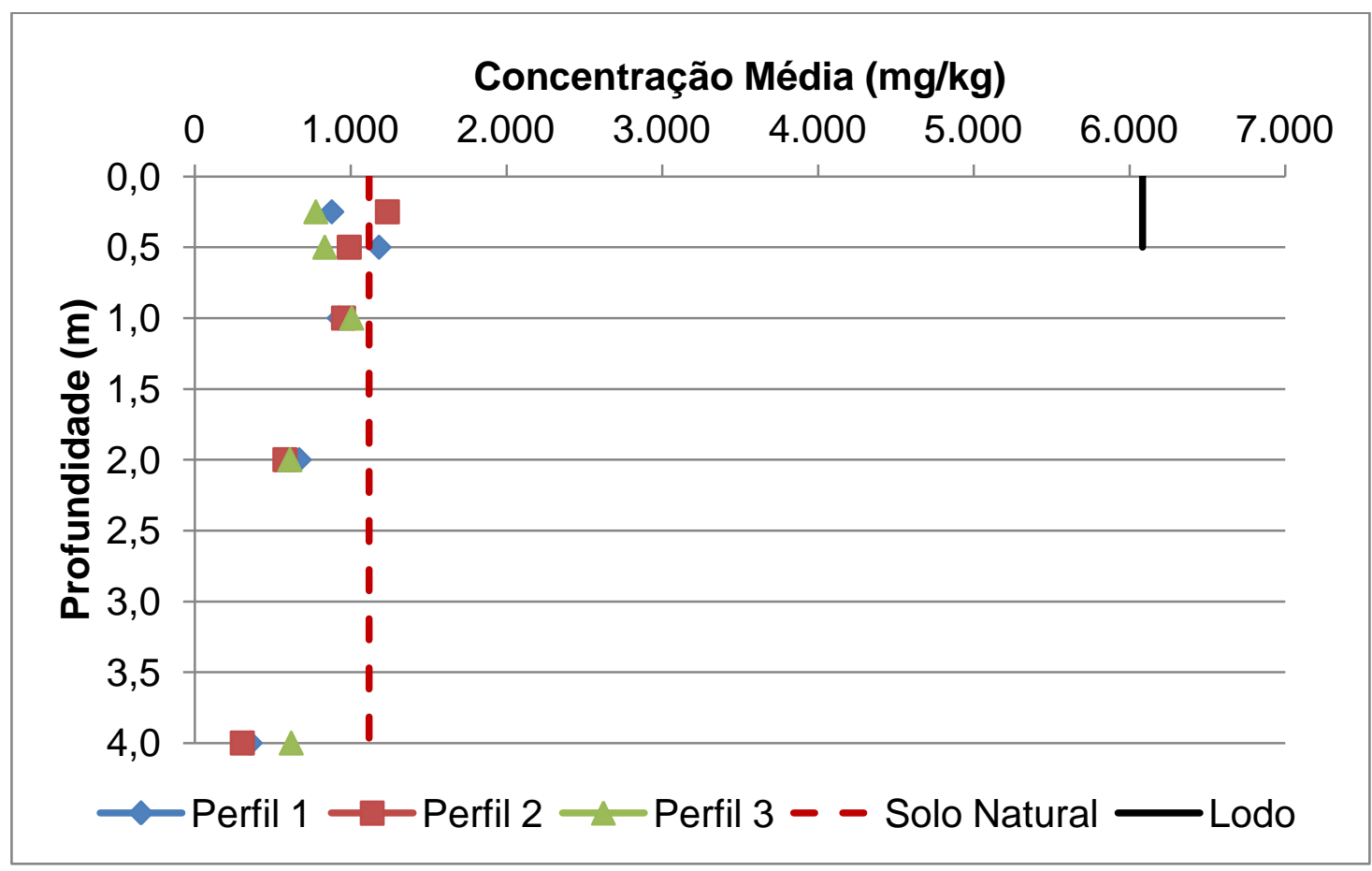

Figura 5-31 - Perfis de contaminação do carbono orgânico total no subsolo da lagoa não impermeabilizada. 


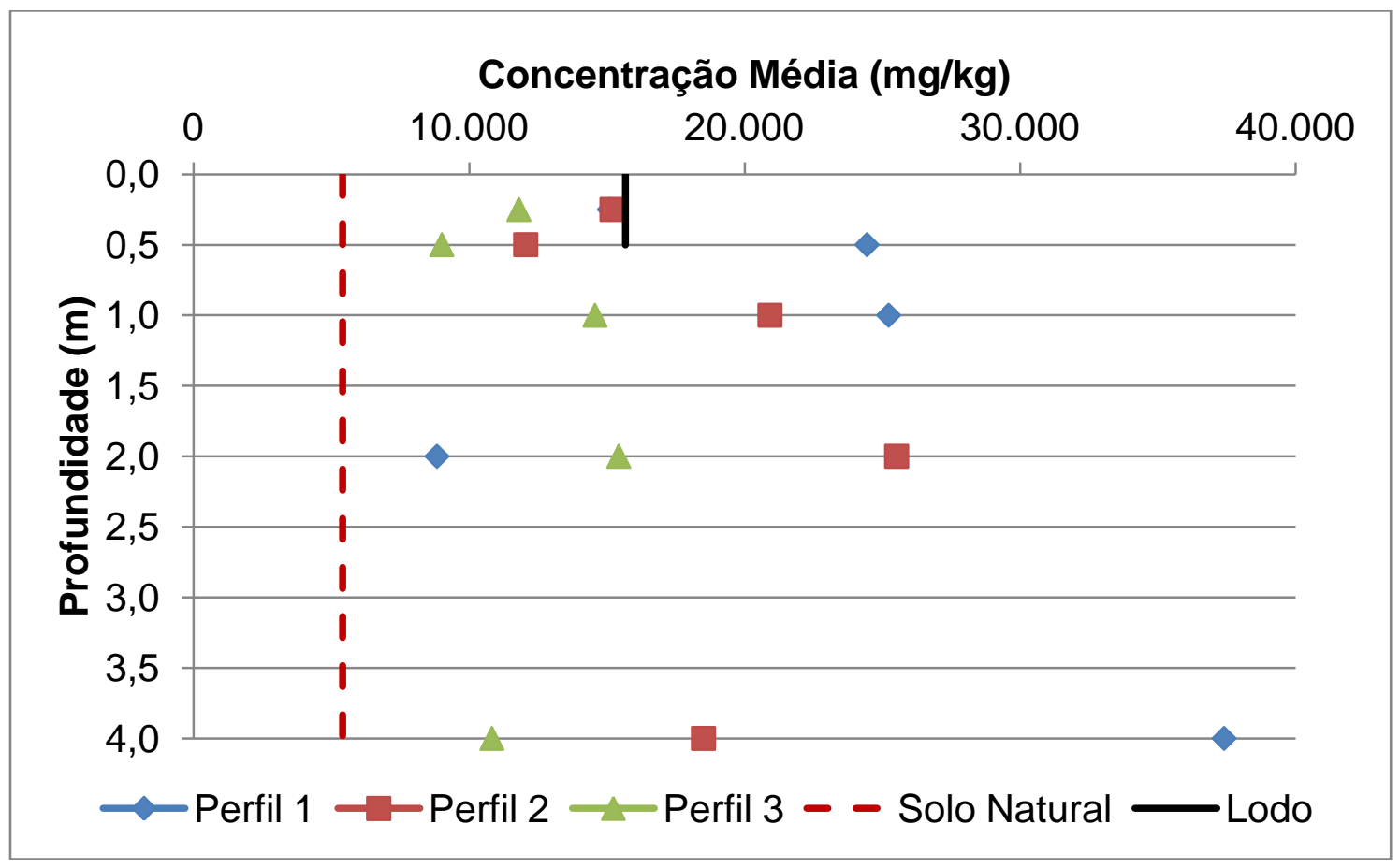

Figura 5-32 - Perfis de contaminação do nitrogênio Kjeldahl total no subsolo da lagoa não impermeabilizada.

A partir dos resultados obtidos, é possível observar:

- As concentrações de cloreto determinadas nas amostras de solo contaminado são superiores à do solo natural (background), enquanto a maioria dos valores está abaixo da concentração no lodo. Comparando-se os três perfis, a variação entre as concentrações em cada profundidade é significativa. Observa-se que a concentração de cloreto a $4 \mathrm{~m}$ de profundidade é próxima à do solo natural nos três perfis. A $2 \mathrm{~m}$ de profundidade, o perfil 3 ainda apresenta uma concentração de cloreto da ordem de grandeza do lodo. Apesar da heterogeneidade, pode-se observar um padrão de comportamento de variação de concentração do íon ao longo da profundidade semelhante para todos os perfis;

- A maioria das concentrações de carbono orgânico total nas amostras de solo contaminado é inferior à do solo natural (background). A variação das concentrações ao longo da profundidade, diminuindo a partir de 0,5 m, é semelhante nos três perfis. A concentração a $4 \mathrm{~m}$ de profundidade é aproximadamente metade em relação à do solo natural e 1/10 em relação à do lodo; e 
- As concentrações do nitrogênio Kjeldahl total nas amostras de solo contaminado são superiores à no solo natural (background) e grande parte, também à no lodo. Assim como para o cloreto, a variação entre as concentrações nos três perfis é significativa. Tampouco se observa um padrão de comportamento de variação de concentração ao longo da profundidade semelhante para todos os perfis. As concentrações continuam elevadas a $4 \mathrm{~m}$ de profundidade.

Comparando-se os valores de concentração no lixiviado e no lodo, o cloreto e COT estão na mesma ordem de grandeza, de ppm. O NKT, por outro lado, encontra-se na ordem de ppm no lixiviado e partes por milhar no lodo.

A Tabela 5-11 apresenta uma comparação dos valores obtidos nesta pesquisa e na de Ferrari et al. (2010) para cloreto, COT e NKT. Nesta pesquisa, as concentrações no lodo de cloreto e NKT são, respectivamente, inferior (aproximadamente 1/3) e superior (cerca de 3 vezes) às encontradas por Ferrari et al. (2010); as concentrações de COT no lodo foram muito próximas nos dois casos. Porém, no solo contaminado, a distribuição de concentrações nos dois trabalhos apresentam faixas de valores bastante diferentes.

Tabela 5-11 - Concentrações obtidas em Ferrari et al. (2010) e nas amostras estudas nesta pesquisa.

\begin{tabular}{|c|c|c|c|c|c|c|}
\hline \multirow{2}{*}{ Elemento } & \multicolumn{3}{|c|}{ Ferrari et al. (2010) } & \multicolumn{3}{c|}{$\begin{array}{c}\text { Amostras do aterro sanitário de } \\
\text { Botucatu/SP }\end{array}$} \\
\cline { 2 - 3 } & $\begin{array}{c}\text { Concentração no } \\
\text { solo contaminado } \\
\text { (mg/kg) }\end{array}$ & $\begin{array}{c}\text { Concentração } \\
\text { no lodo } \\
\text { (mg/Kg) }\end{array}$ & $\begin{array}{c}\text { Concentração no } \\
\text { solo contaminado } \\
\text { (mg/kg) }\end{array}$ & $\begin{array}{c}\text { Concentração } \\
\text { no lodo } \\
\text { (mg/Kg) }\end{array}$ \\
\cline { 2 - 3 } & Mínima & Máxima & & Mína & Máxima & \\
\hline Cloreto & 123 & 322 & 1.788 & 168 & 880 & 735 \\
\hline COT & 9.200 & 230.000 & 6.100 & 279 & 1.315 & 6.082 \\
\hline NKT & 289 & 2.363 & 4.645 & 8.617 & 37.606 & 15.676 \\
\hline
\end{tabular}

O cloreto e o nitrogênio aparentemente foram mobilizados pelo subsolo, ficando retidos em concentrações elevadas nas partículas sólidas do solo. Pode-se afirmar que essas espécies químicas acumularam-se até pelo menos a profundidade de $4 \mathrm{~m}$ tendo como fonte o lixiviado ou lodo na superfície.

O carbono orgânico total no subsolo foi detectado em concentrações bastante inferiores à presente no lodo, em muitos casos inferiores à concentração no próprio 
solo natural. O COT, material derivado de vegetação decomposta, crescimento bacteriano, atividades metabólicas de organismos vivos ou de compostos orgânicos, está relacionado ao equilíbrio de nitrogênio e fósforo no solo. A diminuição do COT com a profundidade até valores inferiores ao background pode estar relacionada ao transporte de nitrogênio e fósforo através do subsolo e seu consumo por microrganismos. 


\section{CONCLUSÕES}

A condutividade hidráulica do solo natural à água é da ordem de $1 \times 10^{-6} \mathrm{~m} / \mathrm{s}$, mas varia com o gradiente hidráulico aplicado e a duração do ensaio. $O$ aumento do gradiente hidráulico de 5 para 15 acarreta uma diminuição na condutividade hidráulica, assim como o aumento da duração do ensaio.

Em um ensaio de permeabilidade longo, no qual ocorre a percolação de um volume de água suficiente para trocar muitas vezes a água dos poros, a condutividade hidráulica pode diminuir em até uma ordem de grandeza. Atenta-se assim para a necessidade de discutir no meio técnico os critérios de parada de ensaios de permeabilidade e de coluna, tanto para permitir a comparação entre diferentes pesquisas, como para possibilitar previsões mais realistas para projetos.

A percolação de lixiviado do aterro sanitário de Botucatu acarretou a diminuição da condutividade hidráulica do solo natural para $6,0 \times 10^{-9}$ a $7,1 \times 10^{-7} \mathrm{~m} / \mathrm{s}$, considerando-se ensaios com diferentes gradientes e durações.

No ensaio com gradiente hidráulico igual a 5, ocorreu a colmatação do solo com interrupção da percolação. Aumentado o gradiente para 13, a percolação pelo corpode-prova foi reestabelecida. Esta é uma limitação importante do ensaio de coluna com lixiviado real: nas situações de campo de uma lagoa de acumulação de lixiviados e de liners de aterros sanitários, os gradientes são inferiores aos aplicados no ensaio que ocorreu a colmatação do solo.

A colmatação do solo também pode ser observada no solo contaminado sob a lagoa de lixiviado: constatou-se durante a amostragem do solo que até cerca de $0,5 \mathrm{~m}$ de profundidade os vazios do solo estavam ocupados por uma matéria pastosa, o lodo depositado no fundo da lagoa, que provavelmente dificultava a passagem do lixiviado armazenado na lagoa e retardava a frente de contaminação.

Nos ensaios de coluna com lixiviado, as concentrações medidas apresentaram muita dispersão, mas pode-se mesmo assim constatar que as concentrações efluentes dos elementos eram superiores às concentrações afluentes. Os resultados não correspondem ao comportamento clássico de ensaios de coluna, nos quais as concentrações efluentes crescem do valor nulo até a concentração na solução 
afluente. A composição do lixiviado de aterro sanitário, com presença de muitos elementos em concentrações distintas, pode explicar o comportamento complexo observado nestes ensaios de coluna: os elementos presentes competem entre si pelos sítios de adsorção, sendo adsorvidos e causando a dessorção e a dissolução de elementos presentes naturalmente no solo. Portanto, não foi possível obter o coeficiente de dispersão hidrodinâmica e o fator de retardamento para os ensaios de coluna.

Para o ferro, manganês e zinco, a concentração máxima (pico) ocorreu para um volume percolado de lixiviado de, aproximadamente, 2 volumes de vazios. A partir deste volume percolado, as concentrações desses elementos diminuíram drasticamente, mantendo-se próximas ou inferiores às concentrações correspondentes no lixiviado. Possivelmente o lixiviado mobilizou o ferro, o manganês e o zinco presentes naturalmente no solo devido à diferença de $\mathrm{pH}$ e carga iônica em relação à água dos poros.

A ampla bibliografia de parâmetros de transporte de metais em solos geralmente baseia-se em ensaios com soluções sintéticas. Em um lixiviado real gerado na massa de RSU - como o que percolou através das camadas subjacentes da lagoa de acumulação de lixiviado do aterro sanitário de Botucatu e foi utilizado para os ensaios de laboratório com amostras de solo não contaminado - ocorre a competição entre os diversos íons e moléculas constituintes do lixiviado pelos sítios de adsorção nas partículas sólidas do solo. Além disto, as concentrações dos diversos solutos podem ser alteradas por reações de natureza bioquímica, dada a elevada carga orgânica e de macronutrientes do lixiviado, condições favoráveis ao crescimento microbiano.

Ademais, a aplicação de gradiente baixo, situação mais representativa de configurações operacionais de aterros sanitários, acarretou a colmatação dos poros do solo. A utilização de gradiente elevado, evitando a colmatação, não representa adequadamente a situação de campo. Cria-se assim um impasse para a obtenção de parâmetros representativos de transporte de poluentes de lixiviado real de aterro sanitário em solo por meio de ensaios de coluna.

$\mathrm{Na}$ análise da contaminação de campo, foram encontradas cinco situações relacionadas aos elementos químicos estudados: o cádmio não foi detectado no solo 
natural, no lodo e nos perfis; arsênio e níquel não foram detectados no solo natural nem nos perfis, mas foram detectados no lodo; o zinco não foi detectado no solo natural, mas foi detectado no lodo e nos perfis; os elementos chumbo, cobre e manganês foram detectados no solo natural (background), no lodo e em todas as amostras dos perfis; o ferro também foi detectado no solo natural (background), no lodo e em todas as amostras dos perfis, porém em concentrações muito superiores às dos demais elementos, até três ordens de grandeza mais elevadas do que as dos outros elementos.

Com base na distribuição de concentrações em função da profundidade para cada elemento, pode-se concluir que, mesmo tendo ocorrido transporte de poluentes da lagoa de lixiviado para o subsolo, com aumento de concentrações em relação ao background do solo, não pode se considerar que o solo esteja contaminado pelos elementos investigados, com base nos valores limites de contaminação da legislação vigente (CETESB, 2005; CONAMA, 2009).

É interessante observar que, para os elementos detectados, as concentrações no lixiviado eram muito inferiores às no lodo. É possível que o lodo depositado no fundo da lagoa funcione, ao mesmo tempo, como adsorvente dos constituintes do lixiviado (sorvedouro) e como fonte concentrada de poluentes que podem ser mobilizados para o subsolo.

O cloreto e o nitrogênio, aparentemente, foram mobilizados pelo subsolo, ficando retidos em concentrações elevadas nas partículas sólidas do solo. Pode-se afirmar que essas espécies químicas acumularam-se até pelo menos a profundidade de $4 \mathrm{~m}$ tendo como fonte o lixiviado ou lodo na superfície.

O carbono orgânico total no subsolo foi detectado em concentrações bastante inferiores à presente no lodo, em muitos casos inferiores à concentração no próprio solo natural. A diminuição do COT com a profundidade até valores inferiores ao background pode estar relacionada ao transporte de nitrogênio e fósforo através do subsolo e seu consumo por microrganismos. 
Considerando os objetivos propostos para esta investigação, conclui-se que:

- apesar do fato do solo local ser arenoso e poroso, apresentar condutividade hidráulica elevada e possuir baixas fração de argila e capacidade de troca catiônica, os metais investigados (arsênio, cádmio, chumbo, cromo, cobre, níquel e zinco) foram parcialmente retidos no subsolo e não atingiram os valores máximos permitidos da legislação estadual aplicável, mesmo após 15 anos de armazenamento de lixiviado em uma lagoa sem revestimento de fundo. Estes resultados são consistentes com muitos outros estudos sobre transporte e retenção de metais em solos tropicais; e

- a comparação dos resultados obtidos pelos dois métodos permitiu avaliar que os ensaios de coluna não são representativos das condições de campo no transporte de poluentes presentes em lixiviado de aterro sanitário. A investigação em laboratório, por outro lado, possibilitou investigar algumas variáveis de interesse para melhor compreensão dos fenômenos envolvidos, particularmente a influência do gradiente hidráulico e a duração da percolação.

Para o prosseguimento da pesquisa, propõe-se investigar:

- o transporte de poluentes dos constituintes do lixiviado do aterro sanitário responsáveis pela colmatação de meios porosos (como alcalinidade, sulfato, nitrogênio e fósforo) em corpos-de-prova indeformados, buscando entender os mecanismos atuantes na colmatação;

- as concentrações dos constituintes adsorvidos em corpos-de-prova indeformados em ensaios de coluna com lixiviado de aterro sanitário, comparando-as às obtidas pela análise de contaminação de campo realizada nesta pesquisa de mestrado;

- os efeitos da compactação do solo no transporte de poluentes, particularmente na retenção de contaminantes, no retardamento da frente de contaminação e na ocorrência de colmatação;

- ensaios de difusão em amostras indeformadas de solo natural com o lodo depositado na lagoa de acumulação de lixiviado, verificando assim a possibilidade de o lodo funcionar como fonte concentrada de poluentes; e 
- ensaios de transporte de poluentes com lixiviado sintético composto por um elemento traçador, como o cloreto, para reduzir as fontes de incerteza e permitir um melhor entendimento das variáveis atuantes no transporte de poluentes. 


\section{BIBLIOGRAFIA}

AMERICAN SOCIETY FOR TESTING AND MATERIALS - ASTM. ASTM D5084-90: Standard Test Methods for Measurement of Hydraulic Conductivity of Saturated Porous Materials Using a Flexible Wall Permeameter. West Conshohockex, 1990. $23 \mathrm{p}$.

ASSOCIAÇÃO BRASILEIRA DE NORMAS TÉCNICA - ABNT. NBR 6459: Solo determinação do limite de liquidez. Rio de Janeiro, 1984a. 6 p.

. NBR 6508: Grãos de solos que passam na peneira de 4,8 mm determinação da massa específica. Rio de Janeiro, 1984b. 8 p. 1984c. 3 p.

NBR 7180: Solo - determinação do limite de plasticidade. Rio de Janeiro,

. NBR 7181: Solo - análise granulométrica. Rio de Janeiro, 1988a. 13 p.

NBR 7182: Solo - ensaio de compactação. Rio de Janeiro, 1988b. 10 p.

. NBR 13292: Solo - Determinação do coeficiente de permeabilidade de solos granulares à carga constante. Rio de Janeiro, 1995. 8 p.

NBR 14545: Solo - Determinação do coeficiente de permeabilidade de solos argilosos a carga variável -. Rio de Janeiro, 2000. 12 p.

NBR 15849: Resíduos Sólidos Urbanos - aterros sanitários de pequeno porte - diretrizes para localização, projeto, implantação, operação e encerramento. Rio de Janeiro, 2010. 24 p.

ASSOCIACCÃO BRASILEIRA DE EMPRESAS DE LIMPEZA PÚBLICA E RESÍDUOS ESPECIAIS - ABRELPE. Panorama dos resíduos sólidos no Brasil - 2011. São Paulo: ABRELPE, 2012. 184 p. Disponível em: <http://www.abrelpe.org.br>. Acesso em: 20 dez. 2012 
BERNUCCI, L. L. B. Considerações sobre o dimensionamento de pavimentos utilizando solos lateríticos para rodovias de baixo volume de tráfego. 1995. 237 p. Tese (Doutorado) - Escola Politécnica, Universidade de São Paulo, São Paulo, 1995.

BOSCOV, M. E. Geotecnia Ambiental. São Paulo: Oficina de Textos, 2008. 248 p. . Brazilian experience in geo-environmental applications of tropical soils. In: INTERNATIONAL CONGRESS ON ENVIRONMENTAL GEOTECHNICS, 6., 2010, New Delhi. Proceedings. New Delhi: Tata McGraw Hill Education, 2010. v. 1. p. 328-341.

Aplicações Geoambientais de Solos Tropicais (apresentação). In: CONGRESSO BRASILEIRO DE GEOTECNIA AMBIENTAL, 7.: Minas Gerais, 2011.

BOWDERS, J. J. JR.; DANIEL, D. E.; BRODERICK, G. P.; LILJESTRAND, H. M. Methods for testing the compatibility of clay liners with landfill leachate. In: SYMPOSIUM HAZARDOUS AND INDUSTRIAL SOLID WASTE TESTING, 4., 1986. Philadelphia: ASTM, 1986.

BRASIL. Lei $n^{0} 12.305$, de 2 de agosto de 2010. Institui a Política Nacional de Resíduos Sólidos; altera a Lei $n^{\circ}$ 9.605, de 12 de fevereiro de 1998; e dá outras providências. Diário Oficial da União, Brasília, 3 agosto 2010a.

. Decreto $n^{0} 7.404$, de 23 de dezembro de 2010. Regulamenta a Lei no 12.305, de 2 de agosto de 2010, que institui a Política Nacional de Resíduos Sólidos, cria o Comitê Interministerial da Política Nacional de Resíduos Sólidos e o Comitê Orientador para a Implantação dos Sistemas de Logística Reversa, e dá outras providências. Diário Oficial da União, Brasília, 23 dezembro 2010b.

COMPANHIA AMBIENTAL DO ESTADO DE SÃO PAULO - CETESB. Decisão de Diretoria no 195-2005- E, de 23 de novembro de 2005. Dispõe sobre a aprovação dos Valores Orientadores para Solos e Águas Subterrâneas no Estado de São Paulo - 2005, em substituição aos Valores Orientadores de 2001, e dá outras providências. São Paulo, 23 de novembro de 2005

CONSELHO NACIONAL DE MEIO AMBIENTE - CONAMA. Resolução oㅜ 420, de 28 de dezembro de 2009. Dispõe sobre critérios e valores orientadores de qualidade do solo quanto à presença de substâncias químicas e estabelece diretrizes para o gerenciamento ambiental de áreas contaminadas por essas substâncias em decorrência de atividades antrópicas. Diário Oficial da União, Brasília, 30 dezembro 2009. 
CORRÊA, A. C. S. S. Avaliação da capacidade de confinamento de solos tropicais: uma contribuição à escolha de novas áreas para disposição de resíduos sólidos urbanos. 2001. 221p. Tese (Doutorado) - Faculdade de Tecnologia, Universidade de Brasília, Brasília, 2001.

DOMENICO, P. A.; SCHWARTZ, F. W. Physical and chemical hydrogeology. New York: Wiley, 1998, 506p.

EATON, A. D.; FRANSON, M. A. H. Standard methods for the examination of water and wastewater. Washington: American Public Health Association, 2005.

EMPRESA BRASILEIRA DE PESQUISA AGROPECUÁRIA - EMBRAPA. Manual de métodos de análise de solos. Rio de Janeiro: EMBRAPA, 1997, 212p.

Manual de análises químicas de solos, plantas e fertilizantes. Brasília: EMBRAPA, 1999. 370p.

FADIGAS, F. S.; AMARAL-SOBRINHO, N. M. B.; MAZUR N.; ANJOS L. H. C.; FREIXO, A. A. (2002). Natural Concentrations of Heavy Metals in Some Classes of Brazilian Soils. Bragantia, Campinas, v. 61(2), 151-159, 2002.

FERRARI, A.; SCAFF, J. J.; TOYOTA, S. A. N.; JUNIOR, W. S. Exhumation of an unlined leachate lagoon - a case study. In: INTERNATIONAL CONGRESS ON ENVIRONMENTAL GEOTECHNICS, 6., 2010, New Delhi. Proceedings. New Delhi: Tata McGraw Hill Education, 2010. v. 2. p. 623-628.

FÚLFARO, V. J.; BJOMBERG, J. S.. Geologia. In: CINTRA, J. C. A.; ALBIERO, J. H. Solos do interior de São Paulo. São Paulo: ABMS, 1992b, 399p.

GURJÃO, C. M. C. Estimativa de propriedades geoambientais de camadas impermeabilizantes de solos tropicais. 2005. 257p. Tese (Doutorado) - Faculdade de Tecnologia, Universidade de Brasília, Brasília, 2005.

HEMSI, P. S.; BOSCOV, M. E. G.; SHACKELFORD, C. D. Points of zero charge and adsorption for a Brazilian residual soil. In: International Congress on Environmental Geotechnics, 4., 2002, Rio de Janeiro. Proceedings. Lisse: A.A. Balkema, 2002. v. 1. p. $105-111$. 
INSTITUTO BRASILEIRO DE GEOGRAFIA E ESTATÍSTICA - IBGE. Manual técnico de pedologia. $2^{a}$ Ed. Rio de Janeiro: IBGE, 2007. 316 p. (Manuais Técnicos em Geociências)

Mapa de solos do Brasil. Rio de Janeiro, 2001, 1 mapa. Escala 1:5.000.000. Disponível em: <http://www.ibge.gov.br/mapas_ibge/tem_solos.php>. Consulta em 25 jan. 2012.

Pesquisa nacional de saneamento básico - 2008. Rio de Janeiro: IBGE, 2011. 219 p. Disponível em: <http://www.ibge.gov.br/home/estatistica/populacao/con dicaodevida/pnsb2008/PNSB_2008.pdf>. Consulta em 5 dez. 2011.

LANGE, C. N. Contaminação do solo e mobilidade de As, Cd, Mo, Pb e Zn em coluna de solo franco arenoso com cinza de carvão. 2012. 150 p. Dissertação (Mestrado) - Instituto de Pesquisas Energéticas e Nucleares, São Paulo, 2012.

LEITE, A. L. Migração de íons inorgânicos em alguns solos tropicais, com ênfase nos processos de sorção e difusão molecular. 2001. 254 p. Tese (Doutorado) - Escola de Engenharia de São Carlos, Universidade de São Paulo, São Carlos, 2001.

MELFI, A. J.; MONTES, C. R.; Carvalho, A.; FORTI, M.C. Use of pedological maps in the identification of sensitivity of soils to acid depostion: application to brazilian soils. Anais da Academia Brasileira de Ciências, v. 76, n.1, p. 139-145, 2004.

NOGAMI, J. S.; VILLIBOR, D. F. Pavimentacao de baixo custo com solos lateriticos. São Paulo : Vilibor, 1995, 213p.

OLIVEIRA, J. B. Solos do Estado de São Paulo: descrição de classes registradas no mapa pedológico. Campinas: Instituto Agronômico de Campinas, 1999. 108 p.

PEIRCE, J. J.; WITTER, K. A. Termination criteria for clay permeability testing. ASCE, Journal of Geotechnical Engineering, v. 112, n.9, p. 841-854, 1986.

PINTO, C. S. Curso básico de mecânica dos solos. $2^{\text {a }}$ Ed. São Paulo: Oficina de Textos, 2002, 354p.

RITTER, E.; FERREIRA, J. A.; VALADÃO, I. C. R. P.; PIRES, J. A. C. The contamination profile on compacted soil foundation from two experimental cells in Rio das Ostras sanitary landfill, Brazil. In: INTERNATIONAL WASTE MANAGEMENT 
AND LANDFILL SYMPOSIUM, 12, 2009, St. Margarita di Pula. Proceedings. St. Margarita di Pula, IWWG, 2009, 1 CD-ROM.

RODRIGUES, J. E.; ZUQUETTE, L. V.; GANDOLFI, G. Mapeamento geotécnico da região centro-leste do estado de São Paulo. In: CINTRA, J. C. A.; ALBIERO, J. H. Solos do interior de São Paulo. São Paulo: ABMS, 1992b, 399p.

ROWE, R. K.; QUIGLEY, R. M.; BOOKER, J. R. Clayey barrier systems for waste disposal facilities. London New York: E \& FN Spon, 1995, 390 p.

SHACKELFORD, C. D. Waste-soil interactions that alter hydraulic conductivity. In: DANIEL, D. E.; TRAUTWEIN, S. J. Hydraulic conductivity and waste contaminant transport in soil. Philadelphia: ASTM, 1994.

SKEMPTON, A. W. The colloidal "activity" of clays. In: CONFERENCE ON SOIL MECHANICS, 3., 1953, Zurich. Anais: Zurich, 1953.

SOARES, V. Utilização de mistura de solo saprolítico com bentonita na construção de revestimento de fundo de aterros sanitários. 2012. $101 \mathrm{p}$. Dissertação (Mestrado). Escola Politécnica da Universidade de São Paulo, São Paulo, 2012.

SOUTO, G. D. B.; POVINELLI, J. Características do lixiviado de aterros sanitários no Brasil. In: CONGRESSO BRASILEIRO DE ENGENHARIA SANITÁRIA E AMBIENTAL, 24., 2007, Belo Horizonte. Anais. Belo Horizonte, 2007.

SPOSITO, G. The chemistry of soils. New York: Oxford University, 1989, 277p.

STUERMER, M. M.; BOSCOV, M. E. G.; OLIVEIRA, E. Metal transport parameters of a gneiss saprolitic silty soil for liner design. Journal of Geotechnical and Geoenvironmental Engineering, v. 134, p. 509-518, 2008.

TSUGAWA, J. K. Solubilização e difusão reversas de cátions metálicos de uma argila laterítica em meio ácido. 2004. 160 p. Dissertação (Mestrado) - Escola Politécnica, Universidade de São Paulo, São Paulo, 2004.

TSUGAWA, J. K.; BOSCOV, M. E. G.; VELLO, K. L.; OLIVEIRA, E. Dissolution and reverse diffusion of metals in a compacted lateritic clay. In: International Congress on Environmental Geotechnics, $4^{\text {th }}, 2002$, Rio de Janeiro. Proceedings. Lisse: A.A. Balkema, 2002. v. 1. p. 453-458. 
UNICAMP - Universidade Estadual de Campinas. Clima dos municípios paulistas. Campinas. Disponível em: < http://www.cpa.unicamp.br/outras-informacoes/clima muni_086.html >. Acesso em 24 ago. 2012.

United States Environmental Protection Agency - USEPA. Batch-type procedures for estimating soil adsorption of chemicals. Washington, 1992. 99p.

Solid Waste Disposal Facility Criteria - Technical Manual. Washington, 1993.

METHOD 3015A: Microwave assisted acid digestion of aqueous samples and extracts. Washington, 2007a. 25p.

METHOD 3051A: Microwave assisted acid digestion of sediments, sludges, soils, and oils. Washington, 2007b. 30p 